\title{
Influence of Petroleum Deposit Geometry on Local Gradient of Electron Acceptors and Microbial Catabolic Potential
}

\author{
Gargi Singh
}

Thesis submitted to the Faculty of the Virginia Polytechnic Institute and State University in partial fulfillment of the requirements for the degree of

Master of Science in

Civil and Environmental Engineering

\author{
Amy Pruden-Bagchi, Chair \\ Mark Widdowson, Co-chair \\ John T. Novak
}

\author{
February 27, 2012 \\ Blacksburg, Virginia
}

Keywords: Petroleum deposit, geometry, oil spill, coastal contamination, gene biomarkers, Deepwater Horizon, BP oil spill, Gulf of Mexico, qPCR, DGGE, $m c r A, d s r A$, and $c a t 23$ 


\title{
Influence of Petroleum Deposit Geometry on Local Gradient of Electron Acceptors and Microbial Catabolic Potential
}

\author{
Gargi Singh
}

\begin{abstract}
A field survey was conducted following the Deepwater Horizon blowout and it was noted that resulting coastal petroleum deposits possessed distinct geometries, ranging from small tar balls to expansive horizontal oil sheets. A laboratory study evaluated the effect of oil deposit geometry on localized gradients of electron acceptors and microbial community composition, factors that are critical to accurately estimating biodegradation rates. One-dimensional top-flow sand columns with 12-hour simulated tidal cycles compared two contrasting geometries (isolated tar "balls" versus horizontal "sheets") relative to an oil-free control. Significant differences in the effluent dissolved oxygen and sulfate concentrations were noted among the columns, indicating presence of anaerobic zones in the oiled columns, particularly in the sheet condition. Furthermore, quantification of genetic markers of electron acceptor and catabolic conditions via quantitative polymerase chain reaction of $d s r \mathrm{~A}$ (sulfate-reduction), $m c r \mathrm{~A}$ (methanogenesis), and cat 23 (oxygenation of aromatics) genes in column cores suggested more extensive anaerobic conditions induced by the sheet relative to the ball geometry. Denaturing gradient gel electrophoresis similarly revealed that distinct gradients of bacterial communities established in response to the different geometries. Thus, petroleum deposit geometry impacts local redox and microbial characteristics and may be a key factor for advancing attenuation models and prioritizing cleanup.
\end{abstract}




\section{Dedicated to my Mother,}

for what I would believe in, if she didn't believe in me;

and to my Father,

in celebration of his 'fierce resolve and intense commitment'. 


\section{Acknowledgements}

I would like to thank National Science Foundation for funding this research (CBET Environmental Engineering RAPID Award: \#1053221); and Virginia Tech Institute for Critical Technology and Applied Science (ICTAS) along with Institute for Society and the Environment for additional funding and support to this wonderful project.

I want to thank my advisors at Charles E. Via Department of Civil and Environmental Engineering at Virginia Tech, Dr. Amy Pruden, and Dr. Mark Widdowson, for their involvement, encouragement, patience, and generosity throughout this project. I owe them my entire (precious and incomplete) understanding of bioremediation, and this thesis. I sincerely thank them for taking me in and trusting me with this interesting project.

I am very grateful to Julie Petruska, and Elizabeth Smiley for invaluable lab assistance, creative ideas, patience, and help with chemical analysis for this project. Also, I want to acknowledge Nicole Fahrenfeld, and Rachel Kistler from Virginia Tech, Kevin C. Martin, and Sean Ramach from U.S. EPA and Henry de La Gaza from British Petroleum for their invaluable field assistance. I also thank Robert Miles Ellenberg for his work as NSF REU scholar, which further enhanced understanding of dissolution behavior of petroleum hydrocarbon samples.

It is an understatement that I owe a lot to my colleagues, particularly Pruden group. I am eternally grateful to them for baby walking me through the ways of research and for the support they have extended to me.

On a personal note, I want to thank my family for their love and unconditional support. I have been standing on 'shoulders of giants' and I especially want to acknowledge the greatest of all giants: my father, for being the best father and doctor ever. (He will always be remembered.) I want to thank my siblings, Sanket and Dhruv. They are my greatest motivation to go on (with research and life.) 
I also want to thank all my friends; for it is to them that I owe my sanity. I solemnly thank N. Karthik for many important indelible things, least of which is for being both extremely adamant and a very fine person. He oared me towards research, and continues to be my most formidable examiner. For this and everything else, I will always be indebted, (and he will never be forgiven.)

They will always be loved. 


\section{Table of Contents}

CHAPTER 1. INTRODUCTION AND OBJECTIVES .................................................... 1

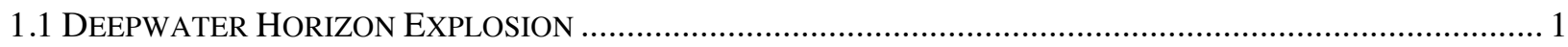

1.2 COMPARISON OF DWH WITH EXXON VALDEZ OIL SPILL ............................................................ 3

1.3 GUlf OF MeXICO OIL SPILl RESPONSE STRATEGIES ................................................................... 5

1.4 ROLE OF GEOMETRY IN ‘FATE AND PERSISTENCE’ ........................................................................ 6

1.5 AN INVESTIGATION IN ROLE OF GEOMETRY ON REDOX CONDITIONS AND FATE OF SPILLED OIL ......... 8

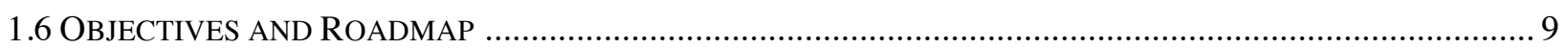

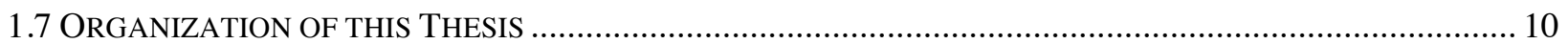

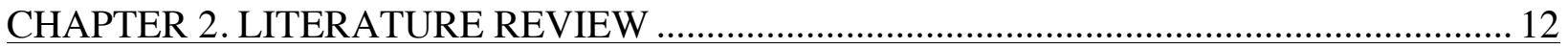

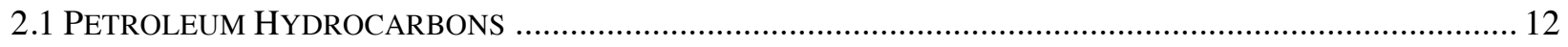

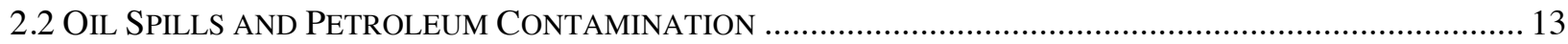

2.3 NATURAL ATTENUATION AND OTHER RESPONSE STRATEGIES ..................................................... 14

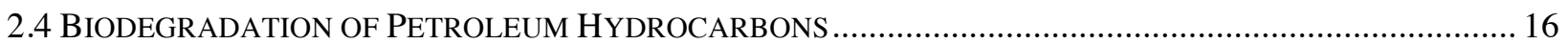

2.5 Role of GEOMETRy of PETRoleum DePosits in DEVELOPMENT OF REDOX CONDITIONS .............. 19

2.6 OVERVIEW OF ROLE OF GEOMETRY OF CONTAMINANT SOURCE IN CURRENT MODELS ..................... 20

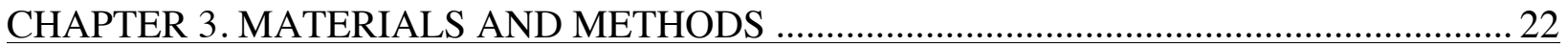

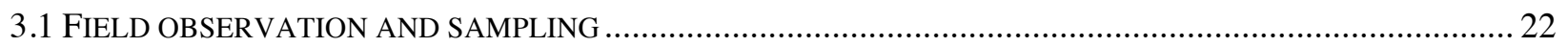

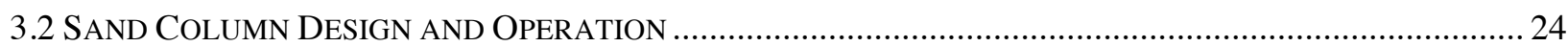

3.3 SAND COLUMN MAINTENANCE AND SACRIFICE ............................................................................. 25

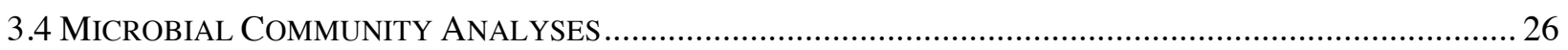

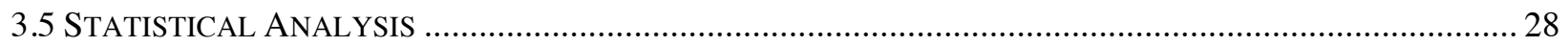

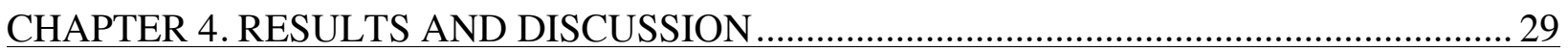

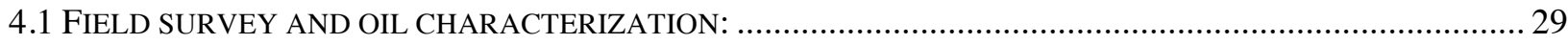

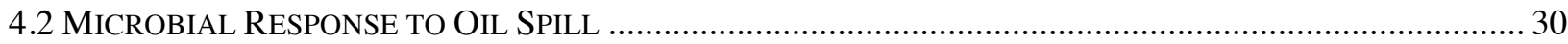

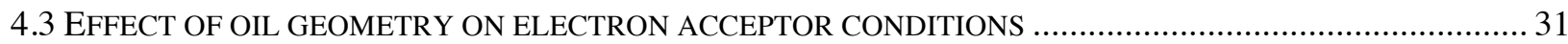

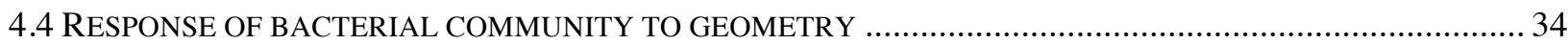

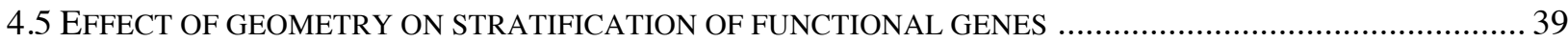

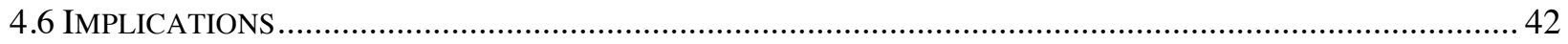


CHAPTER 5. CONCLUSIONS 44

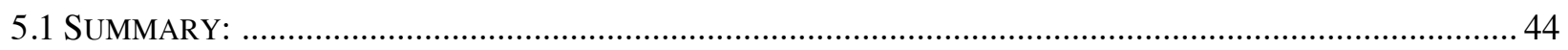

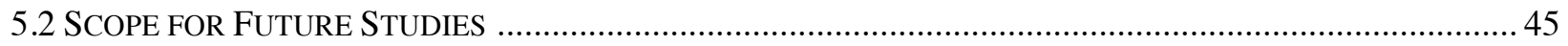

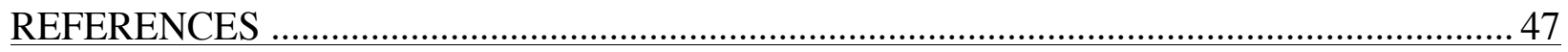

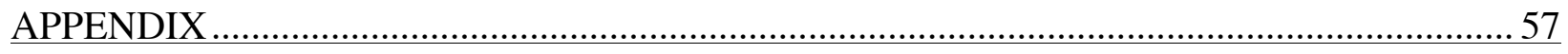

TABLE A1. DETAILS OF SEQUENCES OBTAINED FROM EXCISING THE BANDS FROM DGGE OF THE SAND

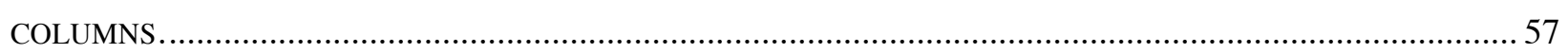

FIG. A1. PARTICLE SIZE DISTRIBUTION OF SAND USED IN 1D SAND COLUMNS. ........................................59

TABLE A2. PRIMER SEQUENCES AND ANNEALING TEMPERATURES EMPLOYED FOR PCR AND QPCR

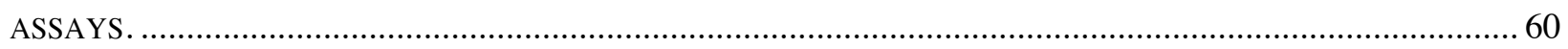

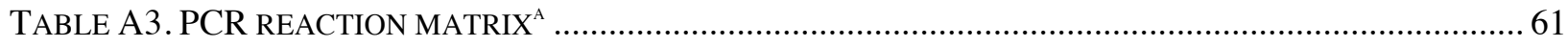

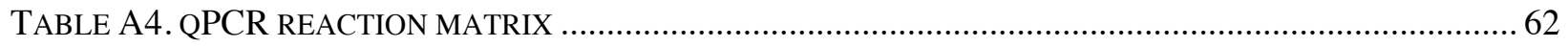

TABLE A5. DNA SEQUENCE ANALYSIS OF CLONED 16S RRNA GENE INSERTS FROM OILED (O) AND

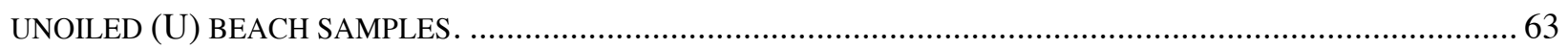

A6. HOTELLING'S T-SQUARE TO COMPARE GC MS ANALYSIS OF THE TAR BALLS AND SHEET OIL DEPOSIT 66

A7. LINEAR MIXED-EFFECT MODELING OF DO AND SO

A8. ANALYSIS FOR SIGNIFICANCE OF QPCR RESULTS FOR MCRA, DSRA, AND CAT23 AS DETERMINED BY

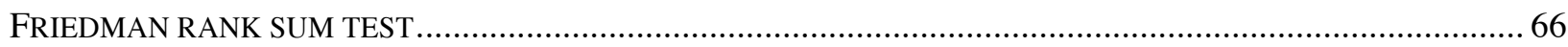




\section{List of Figures}

Fig. 1.1. Illustration depicting the status of oil and natural gas exploration and drilling in Gulf of Mexico as it stood in 1994, (adapted from Kornacki et al. 1994) and 2011(adapted from Ocean Explorer [9]). By 1993 it had been established that Gulf of Mexico was home to recoverable 810 billion bbl oil and $\sim 5$ trillion $\mathrm{ft}^{3}$ natural gas [4]. In December 2006, reserves in Gulf of Mexico Outer Continental Shelf were estimated to be 20.3 billion bbl oil and 183.7 trillion $\mathrm{ft}^{3}$ of gas [10].

Fig. 1.2. A schematic illustrating the role that geometry of petroleum deposits can play in biodegradation of petroleum hydrocarbons. Contrasting geometries of a spherical tar ball and an oil sheet are compared. Surface area to volume ratio of geometry is attributed to influence the dissolution characteristics of contaminant, and thereby influence the bioavailability and biodegradation of the contaminant. Simultaneously, sheet geometry is understood to pose greater obstruction to the flow and therefore the nutrient recharge than the spherical ball geometry. Therefore, theoretically spherical ball with its higher surface area to volume ratio than corresponding sheet geometry, and lesser obstruction to flow, is touted in this figure to undergo faster biodegradation .7

Fig. 2.1. Adapted from Waddill and Widdowson, 2000 [69], this figure illustrates sequential utilization of TEAs by microbes degrading hydrocarbons and highlights the development of zones with different redox potential and biodegradation processes, within and around the contaminant plume

Fig. 3.1. The field survey was conducted west to east in West Point Island and Dauphin Island, AL. Oil samples from deposits of different geometries were collected. Sampling sites in Dauphin Island are highlighted with the numbers depicting the sequence of sampling. Samples of visibly contaminated and visibly uncontaminated sand were collected from four locations as shown.

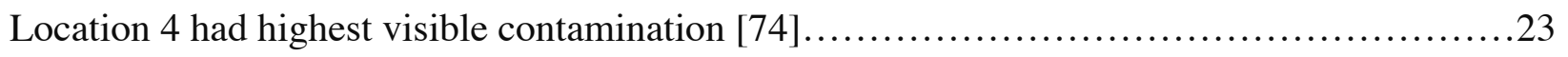


Fig. 3.2. Range of geometries of petroleum deposits were observed on the Gulf shore. a) Raisin sized tar balls, b) mid sized tar balls ranging to few inches in extent, c) sheets or lake of oil

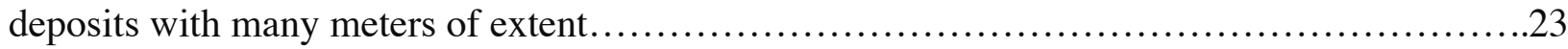

Fig. 3.3. Schematic of sand column set up with tar and sheet deposit geometries. Core sample recovered from the columns with tar ball and disc deposit and with no petroleum deposit. I: Artificial seawater media E: Integrated Effluent. The numbers +5, 0, -2.5, -5, and -7.5 represent depth in cm with respect to the deposit. Samples from these depths were analyzed for genetic markers and community profiling.

Fig. 4.1. Comparison of composition of field-collected oil samples from sheet and ball geometries. Six samples representing geometry were analyzed by GC/MS and the averages and standard deviations of each fraction are indicated. No significant difference in oil composition was found between the two geometries according to a Hotelling's t-squared test .30

Fig. 4.2. A comparison of microbial communities from visibly oiled and unoiled beach sand samples based on 16S rRNA library. 16S rRNA gene library in Table A5 has more information on the kind of bacteria found in visibly oiled and unoiled sand samples.

Fig. 4.3. Dissolved oxygen (DO) concentration in influent and integrated column effluents with time. DO values for ball columns represent the average of duplicates; the blank and sheet columns were single replicates. The slopes and intercept for a linear mixed model fit to the data with corAR1 as a correlation structure were significantly different among blank, sheet, and ball columns

Fig. 4.4. Sulfate concentration the influent and integrated effluent of the columns with time. Sulfate concentrations for ball condition are the average of the duplicate columns, whereas for sheet and blank the data is for a single column. After 28 days significant differences were observed in the slope of the sheet column relative to the ball and blank columns according to linear mixed model fit to the data using corAR1 
Fig. 4.5. DGGE image of transects from core samples from Sheet column, duplicate Ball columns, and Blank column. DNA sequence analysis of highlighted DGGE bands is in Appendix Table A1

Fig. 4.6. Hierarchical cluster of the sub-samples with depth from blank column core. Depths correspond to those sub-sampled from oiled columns. Red dashed lines indicate that the difference between the clustered samples is not significant. $\mathrm{y}$-axis is indicative of Bray-Curtis similarity at which a cluster is formed. Hierarchical clustering was conducted using 'Group average' method [83]

Fig. 4.7. Hierarchical cluster of the samples from the sheet column. Depths correspond to those sub-sampled from oiled columns. Red dashed lines indicate that the difference between the clustered samples is not significant. Y-axis is indicative of Bray-Curtis similarity at which a cluster is formed. Hierarchical clustering was conducted using 'Group average' method [83]...38

Fig. 4.8. Hierarchical cluster of the samples from the duplicate ball columns. Depths correspond to those sub-sampled from oiled columns. Red dashed lines indicate that the difference between the clustered samples is not significant. Y-axis is indicative of Bray-Curtis similarity at which a cluster is formed. Hierarchical clustering was conducted using 'Group average' method [83]...39

Fig. 4.9. Copies of $c a t 23, d s r A$, and $m c r A$ genes in 1-g subsamples of column cores with depth, relative to the oil deposit. Data for ball condition represent the average of duplicate columns, the others are single columns. Error bars represent the standard deviation of triplicates for qPCR for each column core sub-sample. Significant differences with depth were confirmed for the ball and sheet columns according to the Friedman rank sum test (p-values ranging from 0.007-0.015). Differences among ball, sheet, and blank conditions were significant at any given depth (pvalues ranging from 0.002-0.043). An autocorrelation test acf confirmed no significant

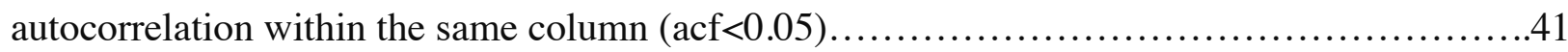


Fig. 4.10. 16S rRNA gene copies per gram of sub-sample of column cores with depth. Data for ball columns is average of duplicate columns. Error bars represent the standard deviation of triplicate qPCR measurements of each sample.

Fig. 5.1. Schematic summarizing nutrient recharge, biodegradation, and dissolution for hydrophobic hydrocarbons

\section{List of Tables}

Table 1.1. The largest marine oil blowouts before Macondo blowout, DWH (adapted from Jernelov, 2010) [5]. Notably, including the DWH blowout in Macondo, the two largest spills following a well blowout occurred in Gulf of Mexico..................................... 3

Table 1.2. Comparison of BP Deepwater Horizon and Exxon Valdez Oil Spills, (adapted from

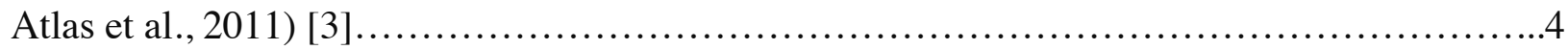

Table 2.1. Adapted from Kostka et al., 2010 [14] to illustrate the difference in chemical composition of petroleum brought in by weathering in the specific case of DWH oil spill.......14

Table 2.2. Electron Acceptors and Gibbs Free Energy (Adapted from Jakobsen 2007 [63])......17

Table 3.1. Recipe for salt water media as adapted from Monserrate et al., 1997 [45]...........26

Table 4.1 Bray Curtis Similarity of DGGE banding patterns of sub-samples of column cores with depth, relative to the oil deposits. .35 


\section{Appendix Figures}

Fig. A1. Particle size distribution of sand used in 1D sand columns.........................59

Fig. A8.1. Autocorrelation plot for cat 23 gene copies.....................................67

Fig. A8.2. Autocorrelation plot for $m c r A$ gene copies...................................68

Fig. A8.3 Autocorrelation plot for $d s r A$ gene copies..................................68

\section{Appendix Tables}

Table A1. Details of sequences obtained from excising the bands from DGGE of the sand columns. The corresponding index numbers are highlighted in Fig. 4.5 in the text, and the depth is with respect to the position of oil deposit as in Fig. 3.3 ...................................57

Table A2. Primer sequences and annealing temperatures employed for PCR and qPCR

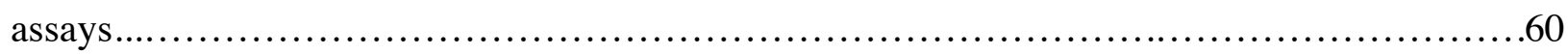

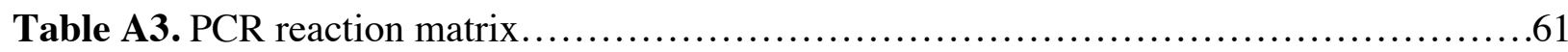

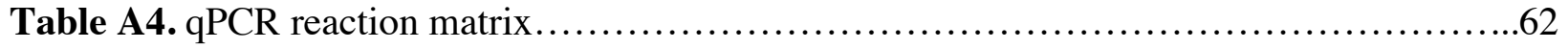

Table A5. DNA sequence analysis of cloned 16S rRNA gene inserts from oiled (O) and unoiled

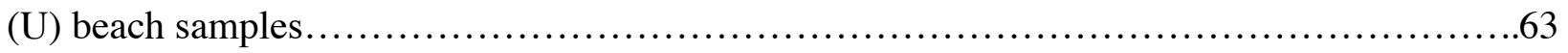




\section{Chapter 1. Introduction and Objectives}

\subsection{Deepwater Horizon Explosion}

Oil and gas exploration plays an important role in economy of Gulf region and has been practiced in this region since 1947, off the coast of Louisiana (Fig. 1.1). It has been suggested that Gulf of Mexico offshore oil and gas industry has potential to generate almost $\$ 300$ billion in

revenues to federal, state, and local governments over the next decade [1]. At present about 1.6 million barrels of oil are produced every day in federal part of Gulf of Mexico. More than 62\% of this comes from deep wells like Deepwater Horizon (DWH) [2]. Activities related to exploration, acquisition, and transportation of oil and gas, have resulted in numerous accidental spills [3-5]. On average, a small fraction of this oil seeps or spills in oceans on a daily basis. U.S. Department of Interior had estimated that nearly 1,800 barrels of oil have been spilled in U.S. waters as a result of blowout from 1970 to 2000 [1]. As a result, gulf region is no stranger to minor oil seeps and spills. In fact its natural oil vents and slicks have been used for more than two decades now, for oil and natural gas exploration [4].

DWH was an oilrig owned by Transocean. It was lent to British Petroleum (BP) from 2001 until 2013. In September 2009, DWH became the deepest oil well in history at a vertical depth greater than $10 \mathrm{~km}$, while use in southeast of Houston [6]. While drilling Macondo prospect, DWH's wellhead Macondo exploded in April 2010. Following failure of blowout prevention device and emergency shut off equipment, high-pressure oil and gas escaped from DWH well [3] and resulted in a human, economic, and environmental disaster [7]. It is estimated that a total of nearly 5 million barrels of crude petroleum [8] were spilled out in ocean from the sea floor leading to contamination of more than $\sim 1050 \mathrm{~km}$ of the Gulf of Mexico coastline [7] 


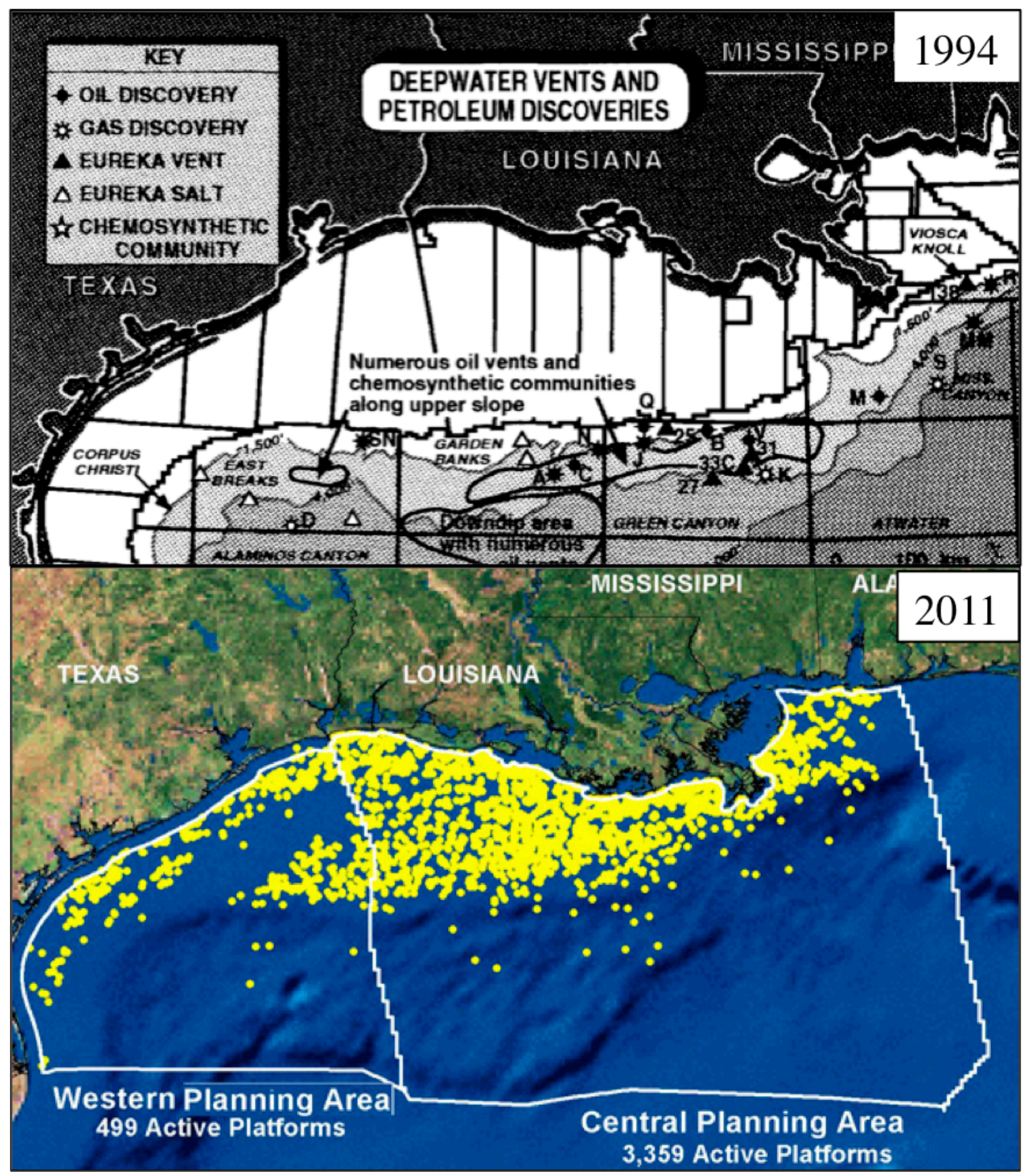

Fig. 1.1. Illustration depicting the status of oil and natural gas exploration and drilling in Gulf of Mexico as it stood in 1994, (adapted from Kornacki et al., 1994) and 2011(adapted from Ocean Explorer [9]). By 1993 it had been established that Gulf of Mexico was home to recoverable 8-10 billion bbl oil and $\sim 5$ trillion $\mathrm{ft}^{3}$ natural gas [4]. In December 2006, reserves in Gulf of Mexico Outer Continental Shelf were estimated to be 20.3 billion bbl oil and 183.7 trillion $\mathrm{ft}^{3}$ of gas [10]. 


\begin{tabular}{lllll}
\hline Well & Country & Year & Tons Spilled & Comments \\
\hline Ixtoc I & Mexico & 1979 & 475000 & \\
Nowruz & Iran & $1983-85$ & 100000 & (After attack by Iraqi planes) \\
Nowruz & Iran & 1983 & 40000 & $\begin{array}{l}\text { (After oil platform was hit by a } \\
\text { tanker) }\end{array}$ \\
Ecofisk & Norway & 1977 & 27000 & \\
Funiwa 5 & Nigeria & 1980 & 26000 & \\
Montara & Australia & 2009 & 20000 &
\end{tabular}

Table 1.1. The largest marine oil blowouts before Macondo blowout, DWH (adapted from Jernelov, 2010) [5]. Notably, including the DWH blowout in Macondo, the two largest spill following a well blowout occurred in Gulf of Mexico.

\subsection{Comparison of DWH with Exxon Valdez Oil Spill}

Another major oil spill in U.S. was the well-studied Exxon Valdez oil spill in Alaska, in 1989. This spill caused extensive damage to marine life, including particularly disturbing death of over a thousand sea otters, Enhydra lutris, and some 300 harbor seals, Phoca vutulina [5]. It was the first spill to face large-scale application of bioremediation measures [3, 11]. This provided precious opportunity for research on response strategies for large-scale oil spills [12]. The Exxon Valdez spill is often compared to DWH spill. However, it is worth noting that the two spills are very different in the type of accident, extent of contamination, kind of ecosystems impacted, and nature of oil as illustrated in Table 1.2.

The oil released from Exxon Valdez spill is classified as heavier crude and had higher aromatic content than the oil that reached the Gulf shores following DWH spill, which is classified as lighter crude $[3,13]$. DWH explosion also resulted in release of considerably large amounts of natural gas [3]. Besides the initial higher biodegradability of Light Louisiana crude oil, DWH 
also had previously acclimated microbial communities in the impacted ecosystem, to its rescue. This was because of natural oil seeps, slicks, and oil and natural gas exploration in the region [4]. Another oil spill of comparable extent was Ixtoc I, which occurred in 1979 in Gulf of Mexico [5], allowed the microbial community to acclimate itself to oil contamination, unlike Exxon Valdez oil spill where the spilled oil was comparatively a new contaminant for the relatively pristine environments [3]. Gulf of Mexico also witnessed extensive use of novel measures at an unprecedented scale to control and mitigate the spill's impact.

\begin{tabular}{lll}
\hline & Exxon Valdez & BP Deepwater Horizon \\
\hline Volume of oil released & 41.6 million liters & Estimated as 779 million liters \\
Oil Type & North Slope Heavy Oil (API 29) & Light Louisiana Oil (API 35.2) \\
Site of Discharge & Surface & Well Head in 1500 m of seawater \\
Bioremediation Strategy & Fertilizers & Aerial and subsurface dispersants \\
Environment impacts & Sub-arctic & Sub-tropical, Seabed. \\
& Much scientific and operating & Largest \\
& experience gained is applicable & emergency response to an oil spill \\
Outcome & to other spills & ever, worldwide
\end{tabular}

Table 1.2. Comparison of BP Deepwater Horizon and Exxon Valdez Oil Spills, (adapted from Atlas et al., 2011) [3]. 


\subsection{Gulf of Mexico Oil Spill Response Strategies}

Crude oil is a complex mixture of hydrophobic components with a wide range of specific gravities. In general, oil being lighter than seawater, floats on the surface and affects coastal birds and marine ecosystem that inhabit the surficial waters in the sea. Floating oil also gets washed up to shore and further contaminates coastal ecosystems. Despite acclimation

opportunities provided by minor oil spills and seeps in Gulf region, DWH spill was a spill of unprecedented large scale and poses a threat on Gulf region's sensitive coastal ecosystems [14].

Different response strategies have been tested on various oil spills [11], and the response to Macondo blowout included physical methods like controlled burns, skimming, siphoning from the well-head, contaminant booms, shoreline scavenging, beach sand mixing, and largely the large scale use of dispersants at wellhead and surface [3]. National Incidents Command's Flow Rate Technical Group' oil budget calculator estimated that of the oil released in the environment from DWH well, $3 \%$ was skimmed, $5 \%$ burned, $8 \%$ was chemically dispersed, $16 \%$ was naturally dispersed, $17 \%$ captured, $25 \%$ was evaporated or dissolved, and $26 \%$ was remaining [3, $15]$.

Use of dispersants is a well-studied strategy for combating the adverse impact of oil, specially those components of oil which float in sea. Dispersants dramatically increase the surface area available for dissolution of oil and microbial colonization $[3,11]$ and dispersed oil results in lesser harm to coasts and surficial life forms [16]. However, it is unclear if use of dispersants near the well head in case of Macondo blowout actually helped in dispersing the oil [17] and aiding biodegradation.

The vast expanse of this spill, extensive application of dispersants on surface and near the well head [18], and warm climate of the Gulf region together imposed unique conditions on the 
released petroleum, presenting an unprecedented challenge in modeling and predicting the fate of petroleum hydrocarbons on the sensitive marine and coastal environments in Gulf of Mexico.

\subsection{Role of Geometry in 'Fate and Persistence'}

As became apparent during the outfall of the disaster, sensitive and accurate models of petroleum fate and persistence are urgently needed to efficiently guide and prioritize cleanup efforts, especially when sensitive coastal ecosystems are at risk. While petroleum hydrocarbons themselves are rich source of organic carbon and are readily biodegradable [19], particularly under aerobic conditions, their extreme hydrophobicity and low solubility [20-23] complicates accurate predictions of natural attenuation rates. One potentially critical factor governing persistence in coastal environments that has generally been overlooked in models is geometry of the contaminant source.

In case of non-aqueous phase liquids (NAPLs) contamination of groundwater it is understood that biodegradation of organic contaminants proceeds sequentially [24] with the highest preference being given to most electronegative electron acceptor. Geometry of the contaminant source is now being recognized as an important factor impacting the fate of NAPLs in the subsurface [25-28]. The geometry of the NAPL dictates the surface area, which in turn drives dissolution rates as well as the available area for microbial colonization [3, 29]. Furthermore, taking the local hydrogeological conditions into account, NAPL geometry can impact recharge, potentially posing a localized obstruction to flow [30]. Thus, "dead zones" exhausted of essential nutrients and electron acceptors may form in proximity to the NAPL. This local condition can have a profound impact on the biodegradation potential and thus the ultimate fate and persistence of the NAPL. In case of oil spills, an assimilable organic carbon source is readily 
abundant $[19,20]$ and therefore nitrogen [31, 32] and electron acceptor [33-35] availability become the limiting factors. Thus, geometry is poised to be a key driver of the microbial colonization $[36,37]$, fate and persistence of oil deposited in the coastal environment.

The immense scale of the Deepwater Horizon spill brought to light a range of petroleum deposit geometries that can wash ashore following a spill. Field observations suggest that as oil traveled ashore it interacted with sand and other particulate matter to deposit stable geometries. While a range of geometries were observed, the tar ball and sheet form represent two extremes of the spectrum. It was hypothesized that these two basic forms impose unique local conditions on nutrient and electron acceptor availability, and thus drive distinct microbial community characteristics in the vicinity of the petroleum deposit.

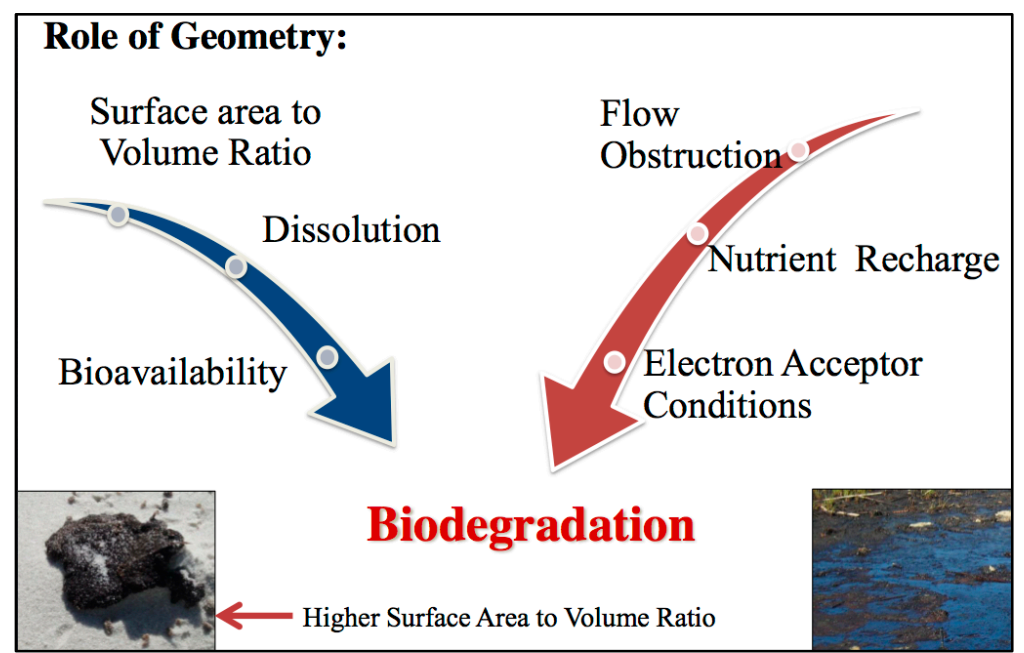

Fig. 1.2. A schematic illustrating the role that geometry of petroleum deposits can play in biodegradation of petroleum hydrocarbons. Contrasting geometries of a spherical tar ball and an oil sheet are compared. Surface area to volume ratio of geometry is attributed to influence the dissolution characteristics of contaminant, and thereby influence the bioavailability and biodegradation of the contaminant. Simultaneously, sheet geometry is understood to pose greater obstruction to the flow and therefore the nutrient recharge than the spherical ball geometry. Therefore, theoretically spherical ball with its higher surface area to volume ratio than corresponding sheet geometry, and lesser obstruction to flow, is touted in this figure to undergo faster biodegradation. 


\subsection{An Investigation in Role of Geometry on Redox Conditions and Fate of Spilled Oil}

The purpose of this study was to demonstrate the effect of petroleum deposit geometry on local redox conditions and the corresponding microbial community composition. It is hypothesized in this study that spherical tar ball geometries have lesser impact on redox conditions around the petroleum deposit than sheet like deposits. Sheet deposits putatively encourage formation of anaerobic conditions below the deposit. Anaerobic degradation is metabolically limited in its kinetics, and is slower than aerobic degradation [38].

Contrasting geometries of spherical tar balls and a sheet molded from equivalent mass of Deepwater Horizon oil was compared to a no oil control in duplicate one-dimensional columns subject to 12 hour tidal cycling. Dissolved Oxygen (DO), and sulfates were monitored in the integrated effluent from the columns as indicators of average redox conditions. Further, cores were obtained from sacrificed columns and were subject to molecular characterization of the microbial communities relative to their spatial orientation to the petroleum deposit. Denaturing gradient gel electrophoresis (DGGE) combined with quantitative polymerase chain reaction (qPCR) quantification of key functional genes related to methanogenesis ( $m c r A$ ), sulfate reduction $(d s r A)$, and meta-cleavage of catechol pathway (cat23) indicative of aerobic aromatic catabolism [39, 40] of column cores provided a snapshot of the impact of geometry on the microbial community structure. Overall this study suggests that petroleum deposit geometry may be a critical factor that should be considered in accurately modeling the ultimate fate and persistence of oil spills and could be of value for prioritizing cleanup of future spills. 


\subsection{Objectives and Roadmap}

The overall objective of this study was to examine the effect of petroleum deposit geometry on local redox conditions and the corresponding microbial community composition. In order to achieve this objective an experimental design, consisting of 1D sand columns and molecular tools for microbial analysis was laid down. The overlying approach of this experimental design was to simulate the field conditions and observe the development of redox gradient around the petroleum deposit by analyzing the microbial communities, which inhabit the neighborhood of the petroleum deposits.

This study began with a field survey having the primary aim of observing and sampling various geometries of petroleum deposits in contaminated regions of Gulf coast. In order to understand the innate differences in the samples from various geometries the samples collected from the field survey were subject to chemical characterization. Based on the results of the chemical characterization, 1D sand columns were set up to resemble the coastal conditions and roughly simulate the tidal cycle. Redox conditions were allowed to set up and the 1D sand columns were sacrificed for further microbial assay.

A summary of the roadmap for the overall objective of this study is:

1) Observation and sampling of petroleum deposits of various geometries on the contaminated coasts in Gulf of Mexico.

2) Comparison of chemical composition of oil from various geometries.

3) 1D Simulation of petroleum deposit of contrasting geometries in coastal environment and allowing the development of redox gradient. 
4) Characterization of the redox gradient developed in 1D simulation of petroleum deposits in coastal environment using tools for microbial community characterization and genetic biomarkers.

\subsection{Organization of this Thesis}

This thesis has been organized in a fashion congruous to the roadmap mentioned in 'Objectives and Roadmap'. It begins with the summary of this study as an abstract, which gives an overview of this study. Chapter 1 is a brief introduction to the background of this study and prepares the reader for details in the further chapters. It includes introductory information on the Gulf of Mexico and DWH accident, on which this this study is largely based upon, and role of redox conditions in driving microbial community and biodegradation of contaminant. It also includes a brief statement of objective of this research and organization of this thesis.

Chapter 2 is the brief summary of literature reviewed during the course of this study. It begins with a brief description of components of petroleum hydrocarbons, their composition, and the biodegradation behavior of different components of oil. Further, the chapter deals with impact of oil spills on environment, and various processes that affect the spilled oil. A brief overview of various strategies to deal with nuisance of oil spills is also presented, including the strategy of natural attenuation of hydrocarbon contaminants. Emphasis is given on biodegradation behavior of petroleum hydrocarbons under various redox conditions. The role which geometry is hypothesized to play in development of local redox conditions, in this study, is conceptually developed on basis of various observations in contaminated coasts of different regions of the world and the well established role that the geometry of contaminant plume of NAPLs, which it is known to play in contaminated groundwater and aquifers. This is followed by a brief overview 
of current models in prediction of persistence of petroleum hydrocarbons and the scope of this research to help fine-tune existing models.

Chapter 3 largely deals with the experimental design, and summarizes its methodology, and materials used in this research. Chapter 4 is a succinct statement of the results of this study. It simultaneously discusses these results and their implications. Chapter 3 and Chapter 4 have been arranged experiment wise, and are in harmony with the sequence of the roadmap. Chapter 5 is a mini-chapter summarizing this thesis and its findings, and suggestions for future studies. 


\section{Chapter 2. Literature Review}

\subsection{Petroleum Hydrocarbons}

Petroleum hydrocarbons are generally found as complex mixtures of thousands of different chemical compounds and they vary in chemical composition with location, age, and depth [4143]. Besides being a rich source of labile carbon, they also often harbor many sulfur, oxygen, and nitrogen compounds. Petroleum hydrocarbons can be broadly classified as aliphatics, napthenes, and aromatics [41]. Aliphatics are saturated hydrocarbons with no ring structures, and are usually most quickly degraded. Among the aliphatics the branched types are usually more resistant to biodegradation [42]. Resistance to biodegradation also increases with increasing chain length (for hydrocarbon chains with more than $4 \mathrm{C}$ atoms) and number of branches [11, 44]. Napthenes are saturated cycloalkanes with or without aliphatic side chains. They tend to be more resistant than their straight chain counterparts. Further, if the cyclic hydrocarbons have resonance in their cyclic rings, then their resistance to biodegradation increases immensely, and they are then classified as aromatics. Petroleum hydrocarbons with one or more aromatic ring are more resilient to biodegradation than their non-aromatic counterparts. One of the reasons for this unusual stability is resonance energy of the aromatic rings. In general aromatic components are also more toxic and therefore are much greater nuisance [33, 45-48].

Aromaticity also lends polarity to hydrocarbons, making them less hydrophobic than their nonaromatic counterparts. Lighter aromatics are usually more volatile and soluble and this usually takes the edge off their toxicity. 


\subsection{Oil Spills and Petroleum Contamination}

Natural gas and oil exploration, and the problem of often-ensuing oil spills have resulted in scientific interest in petroleum biodegradation and petroleum degrading microbial communities. Everyday at least 86 million barrels ( 1 barrel $=42$ gallon (US), 159 liters) of oil is transported by sea [11]. Although less than $2 \%$ of the oil transported gets spilled in the environment [49] and contaminates the sensitive marine ecosystems, considering the volume of oil transported everyday, this amounts to considerable chronic contamination of marine environment worldwide. Petroleum contamination is fairly common and petroleum-degrading microbes are ubiquitous [3, 14, 50]. Microbial communities enriched in genes specific to hydrocarbon biodegradation have been detected in geographically diverse regions including petroleum-contaminated soils of frigid Arctic and Antarctica, marine sediments [14, 25, 36, 51-53].

Even without anthropogenic contamination, hydrocarbons are widely distributed in nature in form of lignin compounds, aromatic amino acids [54], and naturally seeped oil [11]. These naturally existing aromatic hydrocarbons and natural oil seeps have ensured that petroleum degrading microbial communities are wide spread. This causes the happy scenario of quick enrichment of specific microbial communities in response to most oil spills and champions the strategy of natural attenuation as a response to large-scale oil spills.

Specifically, when oil enters oceans, it undergoes various processes collectively known as 'weathering'. The fraction of oil that floats on ocean surface permits volatilization of sufficiently volatile fractions, whereas the wave action disperses the oil globs giving oil-degrading microbes more surface area to feast [55]. Lighter aromatic and other polar fraction of spilled petroleum enjoy higher dissolution and often separate from the bulk oil. Oil globules can further interact with elements (wave action, chemical dispersants, biogeochemical factors, minerals, etc.) and 
emulsify in water to form mousse type of structure or suspension. Gradually oil undergoes bioand photo-degradation. Depending on proximity to coasts, spilled petroleum can travel to shores and interact with coastal eco-, geo-, chemical-systems [11].

During this eventful journey, petroleum interacts with life forms and significantly impacts them. It is known to cause significant shifts in microbial communities of oceans and coasts $[14,17,56$, 57] and negatively impacts most of the higher life forms [5, 7, 16, 22, 23, 49, 58].

Weathering and biodegradation often act in unison, and in case of DWH spill, dramatically changed the chemical composition of spilled petroleum (Table 2.1, [14]).

\begin{tabular}{llll}
\hline Analyte & $\begin{array}{l}\text { Moderately } \\
\text { oiled }\end{array}$ & $\begin{array}{l}\text { Heavily } \\
\text { Oiled }\end{array}$ & $\begin{array}{l}\text { Source } \\
\text { Oil }\end{array}$ \\
\hline Ratio of lighter (C6 to C16) to heavier (C16 to C35) & 0.16 & 0.025 & 2.79 \\
aliphatics & & & \\
\hline
\end{tabular}

Table 2.1. Adapted from Kostka et al., 2010 [14] to illustrate the difference in chemical composition of petroleum brought in by weathering in the specific case of DWH oil spill.

\subsection{Natural Attenuation and other Response Strategies}

Many components of hydrocarbons are toxic and their biological effects lead to environmental concerns, making their attenuation desirable. Oil spills usually have negative effects on higher life forms and result in shifts of microbial communities [11, 16, 31, 49, 56, 58]. Specifically, oil pollution in sea can have long lasting and devastating effects on sensitive marine and coastal ecosystems $[7,59]$.

Petroleum hydrocarbons are rich source of labile carbon $[11,25,56,59]$ and are known to undergo natural attenuation under aerobic, and anaerobic conditions via biodegradation [45, 46, 
$52,60,61]$. Natural attenuation stands as the ultimate fate of majority of oil that enters environment [14] and escapes combustion. However, high dissociation energy of C-H bond of hydrocarbons makes them chemically less reactive [52]. This results in overall slow biodegradation rates and existence of petroleum deposits and plumes. Their propensity to biodegradation is largely decided by their chemical composition and redox condition.

Bioremediation as a response strategy uses capacity of microbial flora to adjust to introduction of different substrates in the environment and eventually utilize them via biodegradation. It aims at increasing the rate of cleanup of petroleum-contaminated area by applying various measures, which include modifying physical and chemical factors (surface area, dissolution, nutrient bioavailability, appropriate terminal electron acceptor (TEA)) to help expedite biodegradation. These techniques aim at enhancing nature's capacity to clean up petroleum contamination as an environmentally responsible measure [11]. Alleviating nutrient limitation by supplying lifesupporting nutrients specially $\mathrm{N}$ and $\mathrm{P}$ is one of those measures and has been practiced in past on a large-scale oil spill Exxon Valdez in Alaska in 1989 [32]. This however suffers limitation of not being equally effective in all instances of oil spill as nutrients are not always limiting [11]. Use of chemical dispersants to increase surface area, dissolution, bioavailability of substrate and nutrients, and therefore enhance biodegradation rate, is another measure, which was practiced on a large scale on ocean surface and well-head in Deepwater Horizon (DWH) oil spill. Application of dispersants rules out the need to bio-stimulate by alleviating limiting nutrients, by increasing surface area and bioavailability of nutrients. However, there have been doubts over benefit of such large-scale application of chemical dispersants [17], and toxicity of chemical dispersants [7]. Bioaugmentation is also advocated as an alternative measure, which consists of inoculating the contaminated sites with microbes, which are better acclimated to the contaminant and are 
well suited to degrade the contaminant or contain it within the plume. Bioaugmentation has been criticized for being based on an erroneous assumption that hydrocarbon degrading microbes do not exist ubiquitously [11]. However, inoculating biomass in order to expedite or initiate biodegradation is a well-established strategy in case of trace level contaminants, waste-water treatment plants, and poly-chlorinated hydrocarbon contamination [62].

\subsection{Biodegradation of Petroleum Hydrocarbons}

Natural attenuation is a slow and gradual process which in presence of appropriate electron acceptors ultimately degrades contaminants which can serve as either C or energy source. Under aerobic conditions a class of enzymes belonging to oxygenases attack the $\mathrm{C}-\mathrm{H}$ bond, whereas anaerobic hydrocarbon degraders use alternate enzyme mechanisms [52]. Anaerobic hydrocarbon degradation has long known to be coupled with methanogenesis, sulfate reduction, and Fe (III) reduction [50], or by anoxygenic photosynthesis [63].

Anaerobic microorganisms exhibit lower growth rates. This is ascribable to thermodynamic limitations of anaerobic TEA and fermentation processes. Table 2.2 highlights Gibbs free energy supplied by TEA considered in this study. Highest energy is available for hydrocarbon-degrading microbes when oxygen is used as a TEA by microorganisms, followed by sulfate and methanogenesis (considering the redox conditions used in this study). This is observed in nature as quick disappearance of most oil components under aerobic environments, when compared to oil in its anoxic stores, which have survived for millions of years with little biodegradation [64]. 


\begin{tabular}{|c|l|l|}
\hline Reaction & $\begin{array}{c}\text { Gibbs Free } \\
\text { Energy } \\
\left(\Delta \mathrm{G}^{\circ} \mathrm{kJ} / \mathrm{e}-\right. \\
\mathrm{eq})\end{array}$ & \multicolumn{1}{|c|}{ Description } \\
\hline$\frac{1}{8} \mathrm{SO}_{4}^{2-}+\frac{19}{16} \mathrm{H}^{+}+e^{-}=\frac{1}{16} \mathrm{H}_{2} S+\frac{1}{16} \mathrm{HS}^{-}+\frac{1}{2} \mathrm{H}_{2} \mathrm{O}$ & 20.85 & $\begin{array}{l}\text { Sulfate } \\
\text { Reduction }\end{array}$ \\
\hline$\frac{1}{4} \mathrm{O}_{2}+\mathrm{H}^{+}+e^{-}=\frac{1}{2} \mathrm{H}_{2} \mathrm{O}$ & -78.72 & Oxidation \\
\hline$\frac{1}{8} \mathrm{CO}_{2}+\mathrm{H}^{+}+e^{-}=\frac{1}{8} \mathrm{CH}_{4}+\frac{1}{4} \mathrm{H}_{2} \mathrm{O}$ & 23.53 & Methanogenesis \\
\hline
\end{tabular}

Table 2.2. Electron Acceptors and Gibbs Free Energy (Adapted from Jakobsen 2007 [65]).

The underlying principal of hydrocarbon biodegradation is that a wide variety of reactions transform the initial substrate into restricted range of central intermediates, which are then usually funneled through common biodegradation pathways [52, 54, 61, 63]. Additionally, biodegradation of aromatic hydrocarbons involves additional series of steps leading to ring cleavage [66].

These metabolic pathways provide key biomarkers in terms of metabolic intermediates, gene markers, etc. for identifying and monitoring attenuation of petroleum. In this study, genes encoding catechol-2, 3-dioxygenase (cat23) [40], dissimilatory sulfite reductase ( $d s r A)$, and methyl coenzyme $M$ reductase ( $m c r A)$ [39] were used as biomarkers for detecting aerobic, anaerobic, and fermentative growth of microbes.

All known methanogens express methyl coenzyme M reductase (MCR) for it catalyzes the last step of methanogenesis by combining the hydrogen donor coenzyme B and the methyl donor coenzyme M [67]. There is a high degree of MCR amino acid sequence conservation among methanogens, including the ones that are phylogenetically distant [68] and this makes it a useful biomarker for detecting methanogenesis in different environments [69]. Methanogenesis is an interesting development in a reactor that is initially replete with TEAs, for it signifies depletion 
of all other TEAs and onset of fermentation. If such a reactor is recharged with TEAs, methanogenesis takes a back seat and bacteria capable of reducing those TEAs overtake.

In this study, sulfate was the dominant TEA after oxygen in the reactor, and with development of anaerobic conditions enrichment of sulfate reducing bacteria (SRB) was expected. SRB carry out dissimilatory sulfate reduction in three steps viz. activation of sulfate by ATP sulfurylase, partial reduction to sulfite, and the final step of reduction to sulfide by dissimilatory sulfite reductase (DSR). DSR is encoded by gene $d s r$, which is more specific to sulfate reduction when compared to genes that encode other enzymes in this process [39]. Therefore, targeting $d s r$ in order to detect SRB is a popular molecular technique $[39,70]$ and was used in this study to detect microbial sulfate reduction.

A gene encoding catechol-2,3-dioxygenase (cat23) was use as a biomarker for aerobic degradation of aromatic compounds, in this study. Aromatic compounds are degraded with help of dioxygenase enzymes to activate and cleave the aromatic ring. Most of the aerobic biodegradation of aromatic hydrocarbon proceeds through the catechol intermediate, which undergoes ring cleavage with help of ortho- or meta-cleavage dioxygenases. cat 23 was chosen as biomarker to detect aerobic biodegradation of aromatic hydrocarbons in this study because genes corresponding to catechol-2,3-dioxygenase have well characterized phylogeny and this pathway is believed to be more capable than catechol-1,2-dioxygenase (, which is an alternate pathway) at biodegradation [71]. It served the dual purpose of detecting the presence of aromatic compounds in the petroleum sample and its aerobic degradation. 


\subsection{Role of Geometry of Petroleum Deposits in Development of Redox Conditions}

As biodegradation progresses TEAs and nutrients get consumed along with the substrate [72]. Depletion of a TEA results in sequential use of other TEAs present in the surrounding, until the region has been depleted of all TEAs and fermentative conditions set in. Such sequential depletion of TEA has been well documented in case of NAPL contaminant plumes in groundwater $[29,72,73]$. In fact, redox gradient has been shown to develop even on a pore scale, when Jakobsen 2007, indicated that separation of redox processes within a single average pore space is possible [65]. Their model further stipulated that if the coatings of organic matter are high enough local redox conditions might bear methanogenic conditions within the pore space itself.

Similar to NAPL contaminant plumes, petroleum deposits on the coast should result in development of redox gradient in its surroundings. Recent studies have gathered evidence for establishment anaerobic conditions and occurrence of anaerobic biodegradation in petroleum contaminated sites [36, 53] with sulfate reduction and methanogenesis often being present [72]. When oil settles in coastal regions to form oil layers on the sediment surfaces, the oil layers provide ideal conditions for anaerobic conditions to develop by restricting the replenishment of TEAs by tide-water, as has been observed in coasts contaminated as a result of Exxon Valdez oil spill [13]. Further, oil sheets have been observed to stimulate formation of layered microbial mats on surface of coasts. These mats had aerobic, photosynthetic cyanobacteria and aerobic heterotrophs on top, and a bottom anoxic layer containing anaerobic microbes. (It was also concluded in this study that the phototrophs observed on top of the microbial mat did not degrade oil, but probably developed some sort of symbiotic relationship [36] with hydrocarbon 
degraders.) Development of such microbial mats supports the concept of development of redox gradient around the petroleum deposit.

The flat, wide-spread extent of the oil layers, as considered in this study [36], would impede nutrient recharge more than the tar balls, which are usually much smaller in size and are often observed in most oil spills. This raises the potential of geometry of petroleum deposit playing a role in dictating redox conditions in local region around the deposit. There is no study, to our knowledge, that compares the potential role of various geometries of petroleum deposits in coastal environment in impacting redox gradient around the petroleum deposit.

\subsection{Overview of Role of Geometry of Contaminant Source in Current Models}

In case of NAPLs in groundwater, substantial field evidence exists in support of presence of multiple electron acceptors within one contaminated site $[72,74,75]$. In presence of multiple TEAs microbes tend to utilize them sequentially, in increasing order of their Gibbs free energy (Table 2.2). In an aquifer, recharge replenishes nutrients and TEAs in the upper boundary of the contaminant plume and results in higher biodegradation in the upper boundary [72]

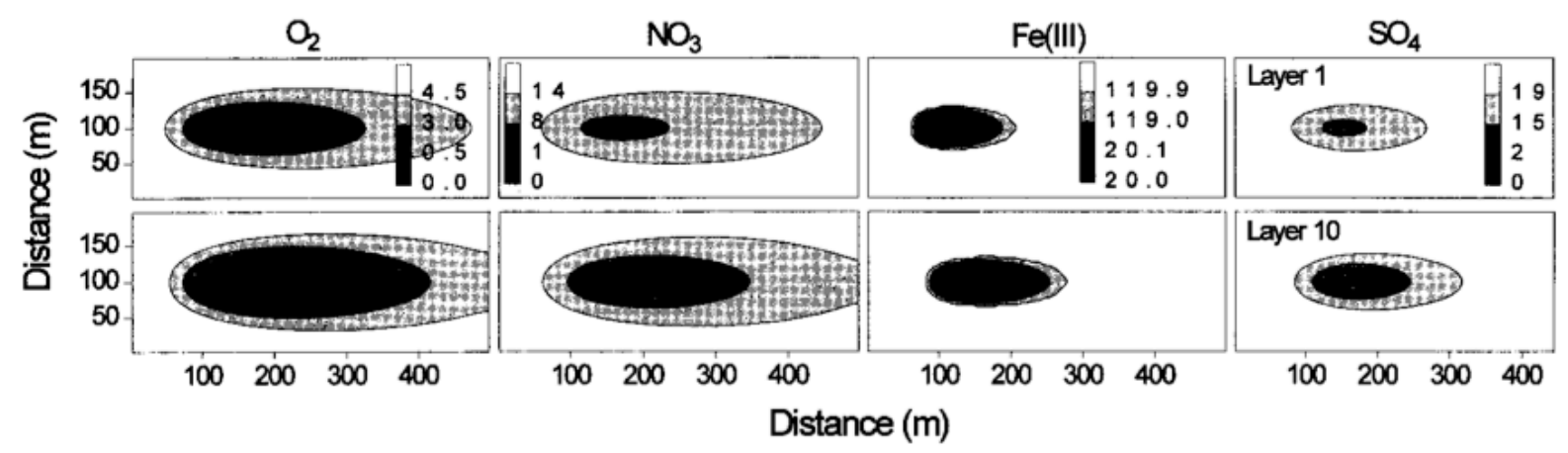

Fig. 2.1. Adapted from Waddill and Widdowson, 2000 [72], this figure illustrates sequential utilization of TEAs by microbes degrading hydrocarbons and highlights the development of zones with different redox potential and biodegradation processes, around the contaminant plume. 
Sequential utilization of TEAs might result in zonation of a contaminant plume with different biodegradation processes dominating in each redox zone [75]. Most of the current models take in account the sequential use of TEAs and transport and uptake of nutrients necessary for microbial growth [75]. As explained in Essaid et al. (2003), these models are of varying complexity depending on the extent to which they represent: 1) physical, chemical, and biological processes; 2) spatial and temporal variability; 3) source-term representation; and 4) solution approach [74]. It has been demonstrated that the rate of dissolution of NAPL into groundwater depends on spatially and temporally variable factors, which include the interfacial area between NAPL and groundwater, and the size and shape of NAPL blobs $[28,72]$. Source zone geometry and size are known to be important in almost all NAPL modeling studies for predicting time-of-remediation for petroleum contaminated groundwater systems [28].

Petroleum contamination on coasts does not suffer the disadvantage of expensive and laborious groundwater contaminant surveys. It is easier to visually survey the deposit geometry (source geometry) and further use it for modeling the persistence of petroleum hydrocarbons in coasts, than in contaminated groundwater. This study attempts to throw light on importance of considering petroleum deposit geometry and its effect on local redox gradient in modeling persistence in coastal environments. Source geometry is a well-established factor considered in most current models for NAPL contamination in groundwater, and its extension to petroleum deposits in coastal environment stands as an interesting prospect in improving models for predicting persistence of petroleum in coastal environments. 


\section{Chapter 3. Materials and methods}

\subsection{Field observation and sampling}

A field survey was conducted west to east from West Point Island to Gulf Shores, AL (Fig. 3.1), on July $27^{\text {th }}$ and $28^{\text {th }}, 2010$, to document the variety and distribution of various geometries of petroleum deposits (Fig. 3.2). Grab samples of seawater, oil (representing both tar ball and sheet deposits), and paired clean and visibly contaminated beach sand (5-15 cm depth, within moist layer) were collected, placed on ice, and transported to $4^{\circ} \mathrm{C}$ storage at the laboratory within 48 hours. Oil samples were eluted in methylene chloride and analyzed by gas chromatography-mass spectrometry (GC-MS) and GC with selected ion monitoring (GC-SIM) to profile the hydrocarbon composition. GC-MS is a very powerful analytical tool for identifying individual compounds in a complex mixture. Initially GC with Flame Ionization Detection (FID) was used to resolve hydrocarbon peaks. It was observed that the beach samples were an extremely complex mixture and it was difficult to resolve interesting peaks, specifically peaks belonging to aromatic components of petroleum hydrocarbon samples from the beach. The purpose of using the mass spectrometer was to finely resolve their peaks. SIM was used to directly target only the aromatic components, which were of interest (chrysene and phenanthrenes) and obtain prettier resolution. Agilent 5973 Mass Selective Detector was used with an Agilent 6890 Series GC system (Agilent Technologies, Wilmington, Delaware) containing a J\&W Scientific (Fisher Scientific, Atlanta, Georgia) DB5-MS fused silica capillary column. The column had a $0.25 \mu \mathrm{m}$ film thickness, a $0.25 \mathrm{~mm}$ narrow bore internal diameter, and a $30 \mathrm{~m}$ length. GC with total ion chromatography (GC- TIC) and GC-SIM were also conducted in kind as an independent analysis by Dr. Roger Prince of Exxon Mobile. 


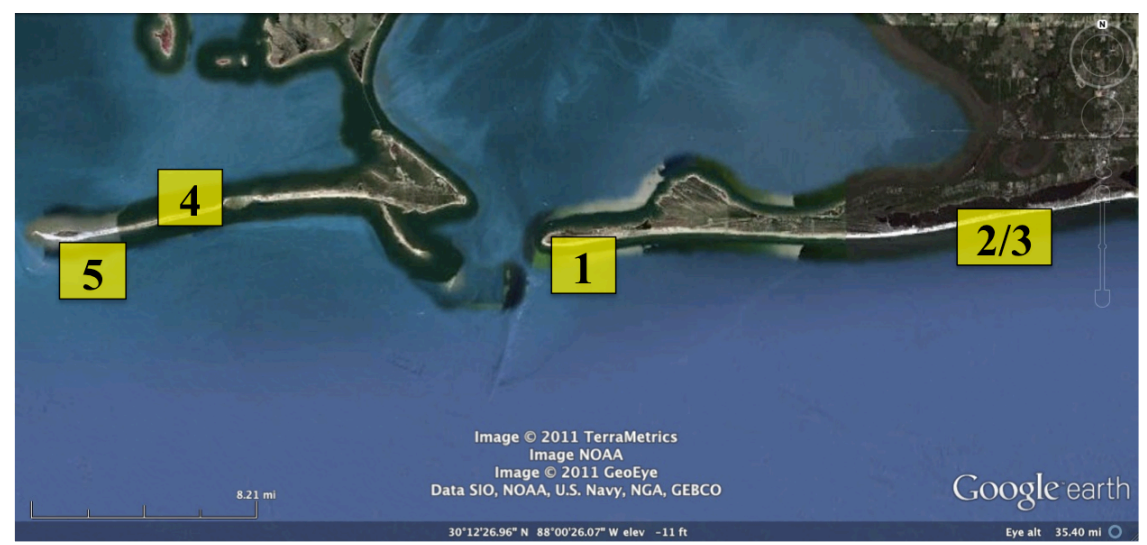

Fig. 3.1. The field survey was conducted west to east in West Point Island and Dauphin Island, AL. Oil samples from deposits of different geometries were collected. Sampling sites in Dauphin Island are highlighted with the numbers depicting the sequence of sampling. Samples of visibly contaminated and visibly uncontaminated sand were collected from four locations as shown. Location 4 had highest visible contamination [76].

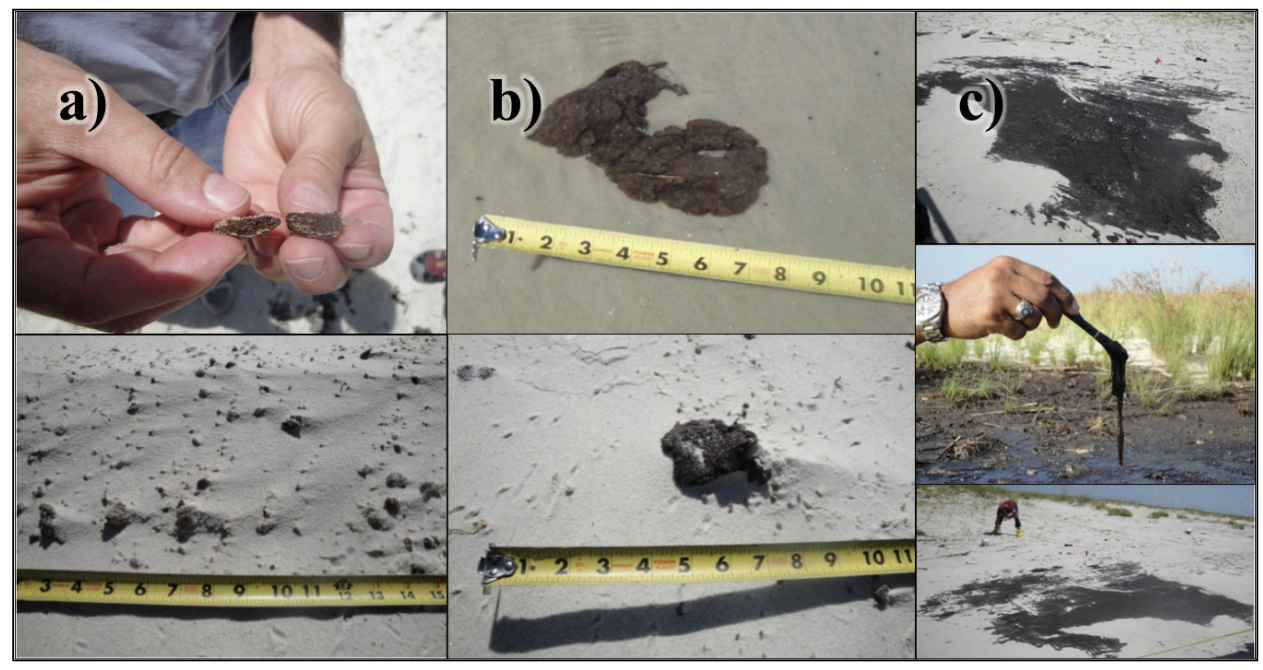

Fig. 3.2. Range of geometries of petroleum deposits were observed on the Gulf shore. a) Raisin sized tar balls, b) mid sized tar balls ranging to few inches in extent, c) sheets or lake of oil deposits with many meters of extent. 


\subsection{Sand Column Design and Operation}

Duplicate 1-D clear PVC sand columns were set up for each of the three conditions: spherical tar balls (ball), disc shaped tar sheet (sheet), and no tar control (blank). The columns were $10 \mathrm{~cm}$ in diameter $30 \mathrm{~cm}$ inches long, and were equipped with a side drainage valve the bottom (Fig. 3.3). Field collected Deepwater Horizon oil samples that had washed ashore were molded into tar balls and sheet and applied at an equivalent total mass of $49.5 \mathrm{~g}$ in each column. The columns with the sheet geometry contained a single deposit of $5 \mathrm{~cm}$ diameter $\mathrm{x} 1.5 \mathrm{~cm}$ height. The columns with spherical deposits contained 17 balls of $\sim 1.5 \mathrm{~cm}$ diameter.
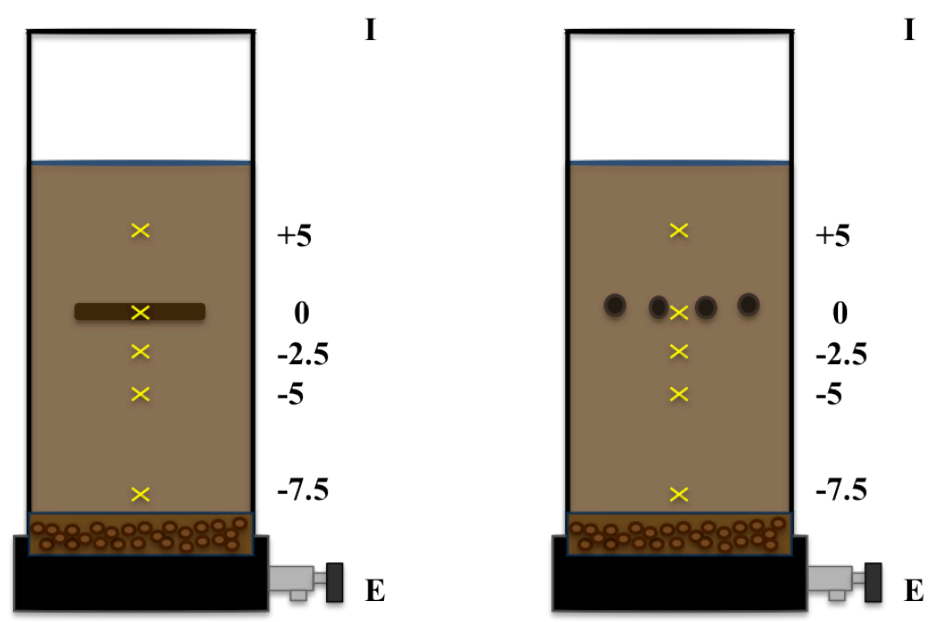

Fig. 3.3. Schematic of sand column set up with tar and sheet deposit geometries. Core sample recovered from the columns with tar ball and disc deposit and with no petroleum deposit. I: Artificial seawater media E: Integrated Effluent. The numbers $+5,0,-2.5,-5$, and -7.5 represent depth in $\mathrm{cm}$ with respect to the deposit. Samples from these depths were analyzed for genetic markers and community profiling. 
The sand (Spectrum Chemicals \& Laboratory Products, Gardena, CA) was characterized using sieve analysis as highly uniform coarse sand with average diameter $>0.5 \mathrm{~mm}$ and uniformity coefficient of 1.088 (Fig. A1). The sand was washed with distilled water and baked at $440^{\circ} \mathrm{C}$ for 16 hours prior to packing the columns (in accordance with ASTM D2974-07a.) The total depth of the sand was $20 \mathrm{~cm}$ with the oil deposited between $7.5 \mathrm{~cm}$ and $10 \mathrm{~cm}$ depth. Post set up, the sand columns were operated in absence of light at a constant temperature of $22^{\circ} \mathrm{C}$. A schematic of the column configuration is provided in Fig. 3.3.

\subsection{Sand Column Maintenance and Sacrifice}

Columns were recharged daily with artificial sea water (Table 3.1) [46] which was prepared fresh daily, autoclaved at $120^{\circ} \mathrm{C}$ for 15 minutes, and cooled down before adding carbonates. Average concentration of sulfate in the prepared media was $1.92 \pm 0.02 \mathrm{~g} / \mathrm{l}$ and that of dissolved oxygen was $6.6 \pm 0.2 \mathrm{mg} / \mathrm{l}$. Seawater is deficient in nitrate and iron [77], and therefore these were not amended to the media as potential TAEs. Columns were top filled with $50 \mathrm{ml}$ of artificial seawater in a nearly instantaneous manner to initiate the $12 \mathrm{~h}$ high tide phase.

Effluent was drawn from the bottom of the column $12 \mathrm{~h}$ later to simulate the low tide phase. The effluent collected provided an integrated sample representative of the entire column. Dissolved oxygen (DO) in the effluent was measured on a daily basis using portable DO probe and a portion of sample was stored at $4^{\circ} \mathrm{C}$ for weekly analysis of sulfate. Sheet column B developed a

leak on the $22^{\text {nd }}$ day of the study and was noted to drain water within nearly four hours of initiating the high tide phase. 


\begin{tabular}{rl}
\hline $\mathrm{NaCl}$ & 23 \\
$\mathrm{MgCl}_{2} \cdot 6 \mathrm{H}_{2} \mathrm{O}$ & 1 \\
$\mathrm{NaHCO}_{3}$ & 2.5 \\
$\mathrm{NH}_{4} \mathrm{Cl}$ & 0.5 \\
$\mathrm{KH}_{2} \mathrm{PO}_{4}$ & 0.2 \\
$\mathrm{KCl}$ & 1.3 \\
$\mathrm{CaCl}_{2} .2 \mathrm{H}_{2} \mathrm{O}$ & 0.1 \\
$\mathrm{Na}_{2} \mathrm{SO}_{4}$ & 2.84
\end{tabular}

Table 3.1. Recipe for salt water media as adapted from Monserrate et al., 1997 [46].

The columns were sacrificed for microbial community characterization after 54 days of operation. $2.1 \mathrm{~cm}$ dia cores were excised from the columns and approximately $2.5 \mathrm{~cm}$ subsamples were separated with depth and stored at $-80^{\circ} \mathrm{C}$ for further analysis.

\subsection{Microbial Community Analyses}

For all molecular analyses, DNA was extracted using the FastDNA® SPIN Kit for Soil and the FastPrep® Instrument (MP Biomedical, Santa Ana, CA) and stored at $-20^{\circ} \mathrm{C}$ prior to analysis.

To compare the bacterial community structure of visibly oiled versus unoiled sand samples, $16 \mathrm{~S}$ rRNA genes were amplified by polymerase chain reaction (PCR) from corresponding DNA extracts using bacterial primers $8 \mathrm{~F}$ and 1492 [78] and cloned using a TOPO TA Cloning® Kit for Sequencing (Invitrogen, Carlsbad, CA). One hundred colonies from each sample were analyzed with restriction endonuclease Msp1 (Promega, Madison, WI) to identify unique operational taxonomical units (OTUs). Unique clone inserts were sequenced by the Virginia 
Bioinformatics Institute (VBI) (Blacksburg, VA). Sequences were compared to the NCBI database using the BLAST tool to identify organisms with the highest sequence similarity. A literature review was conducted of characterized isolates with the highest similarity to assign putative functional groups with respect to hydrocarbon degradation.

Profiles of the bacterial community with depth were captured from the column cores by DGGE. 16S rRNA genes were amplified using primers I-341f GC and I-533r [79] as previously described. The PCR reaction matrix and amplification conditions are described in the Appendix (Table A3). DGGE was performed at $57^{\circ} \mathrm{C}$ with a D-Code system (Bio-Rad, Hercules, CA) employing $8 \%(\mathrm{w} / \mathrm{v})$ polyacrylamide gels with a denaturant gradient from $35 \%$ to $55 \%$. PCR products were electrophoresed at $100 \mathrm{~V}$ for $10 \mathrm{~min}$ and then at $45 \mathrm{~V}$ for $22 \mathrm{~h}$. Gels were stained with SYBRGold (Molecular Probes, Inc., Eugene, OR) and documented using the Chemidoc XRS Gel Documentation System (Bio-Rad). Quantity One 1-D analysis software (BioRad) was used to identify the bands in the gel and obtain intensity profiles for each lane. Visible bands were excised, re-amplified, and sequenced by VBI. Sequences were compared to the NCBI database using the BLAST tool to identify organisms with the highest sequence similarity [80]. qPCR was used to detect and quantify the methyl co-enzyme A reductase ( $m c r A)$, dissimilatory sulfite reductase A ( $d s r A)$, and catechol 1,2-dioxygenase (cat23) functional genes characteristic of methanogenesis, sulfate reduction, and aerobic degradation of aromatic hydrocarbon via catechol intermediate, respectively, as recently described $[39,40]$ (Table A4). qPCR was applied to the DNA extracts obtained from subsamples of column cores with depth to obtain profiles of redox and catabolic potential for aerobic aromatic degradation. 


\subsection{Statistical Analysis}

Statistical analyses were conducted using R software [81] and Primer E [82]. Hotelling's t-square [83] test was used to compare GC-MS analysis of the tar balls and sheet oil deposit samples. A linear mixed-effect model was fit to dissolved oxygen and sulfate of sand column effluents [84] using corAR1 as a correlation structure. corAR1 was selected as correlation structure after fitting an autoregressive time series model to the data by default selecting the complexity by Akaike information criterion (AIC). Significance of $\mathrm{qPCR}$ results for $m c r \mathrm{~A}$, dsrA, and cat23 was determined by Friedman rank sum test. Autocorrelation between samples from the same column was also tested and verified not significant for each column type. Hierarchical clustering was done on the basis on Bray Curtis similarity of square root transformed intensity for each band in DGGE image using Primer E [85]. A p-value $<0.05$ was considered significant in this study. Details of all statistical analyses are available in Appendix A6- A8. 


\section{Chapter 4. Results and Discussion}

\subsection{Field survey and oil characterization:}

A wide variety of petroleum deposits were observed on the beaches of West Point and Dauphin Islands ranging from asymmetrically-shaped tar balls of $0.5-5 \mathrm{~cm}$ of diameter to larger pools of oil positioned as horizontal layers with dimensions ranging from $1.5 \mathrm{~m}$ x $6 \mathrm{~m}$ up to $6 \mathrm{~m} \times 21 \mathrm{~m}$. The same basic geometric forms were observed to be covered by sand, in some instances, suggesting that the surficial deposits were representative of subsurface deposits. The two basic geometric forms chosen for this study, namely the spherical ball and sheet deposit, represent two extremes of the spectrum observed in the survey.

GC-MS analysis of the field samples indicated that the oil composition was consistent across geometries and predominantly consisted of alkanes C11-C25 (Fig. 4.1). Independent laboratory analysis by GC-SIM confirmed that alkanes were dominant, but also indicated the presence of trace levels of chrysene, phenanthrenes, and dibenzothiophenes. The oil was observed to be highly weathered with only trace levels of aromatics at the time of sampling. The similar composition of oil samples from petroleum deposits of different geometries justified pooling oil samples to create simulated sheet and tar balls for the sand column experiment 


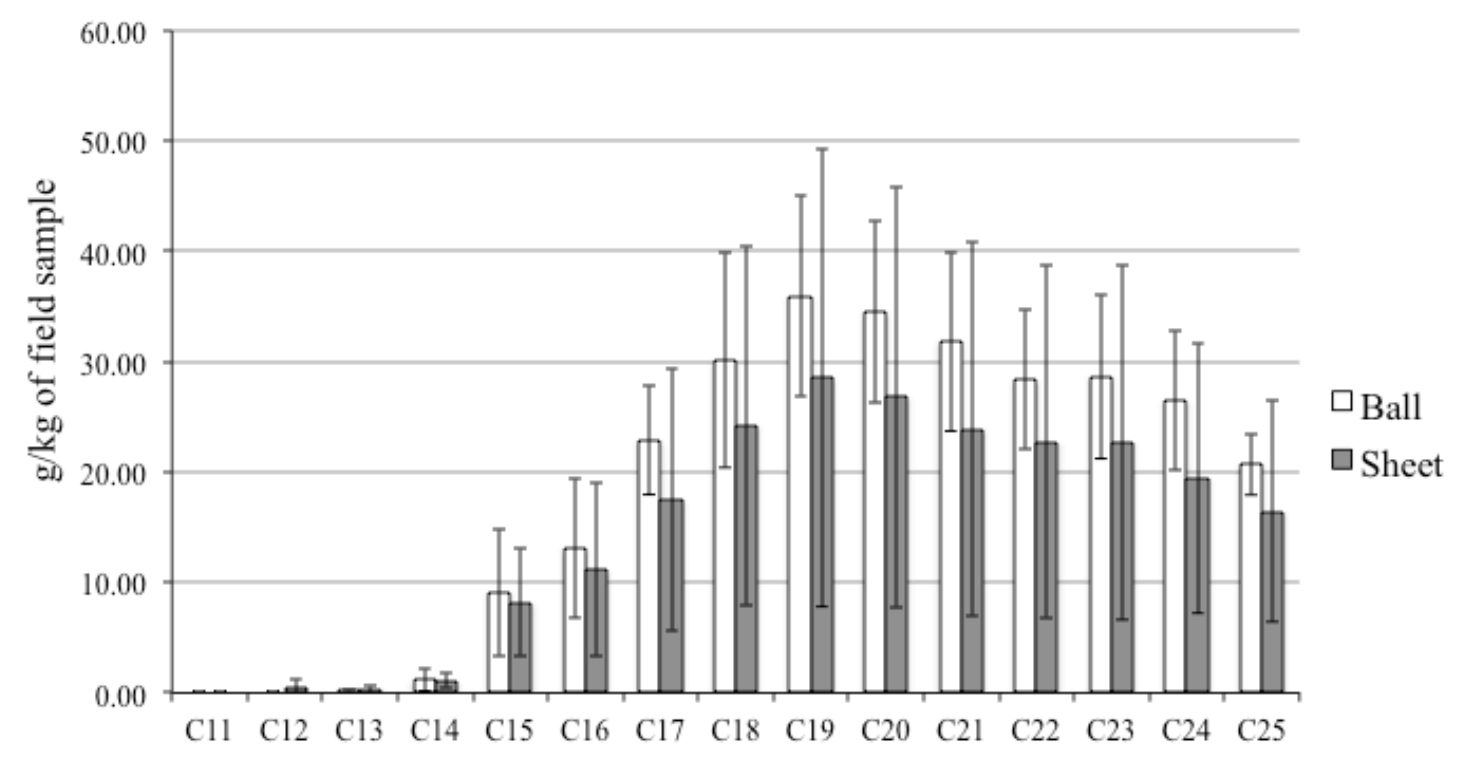

Fig. 4.1. Comparison of composition of field-collected oil samples from sheet and ball geometries. Six samples representing a geometry were analyzed by GC/MS and the averages and standard deviations of each fraction are indicated. No significant difference in oil composition was found between the two geometries according to a Hotelling's t-squared test.

\subsection{Microbial Response to Oil Spill}

Natural oil seeps and small spills are common in the Gulf of Mexico. Thus, native microbial communities inhabiting this region are regularly exposed to oil contamination. However, the oil spill of April 2010 resulted in unprecedented large-scale contamination of the coasts. Comparison of 16S rRNA gene libraries of visibly contaminated and uncontaminated beach samples indicated rapid enrichment of putative oil degraders in the beach environment in response to the oil. $48 \%$ cloned 16S rRNA genes selected from visibly contaminated beach sand sample were most similar to putative oil degraders, versus only $8 \%$ from the visibly uncontaminated beach sand sample (Table A5). This suggests that microbial response and 
presence of oil-degrading microbes is not a limiting factor governing persistence, which is in good agreement with the rapid enrichment of oil degraders observed in the off-shore environment [56].

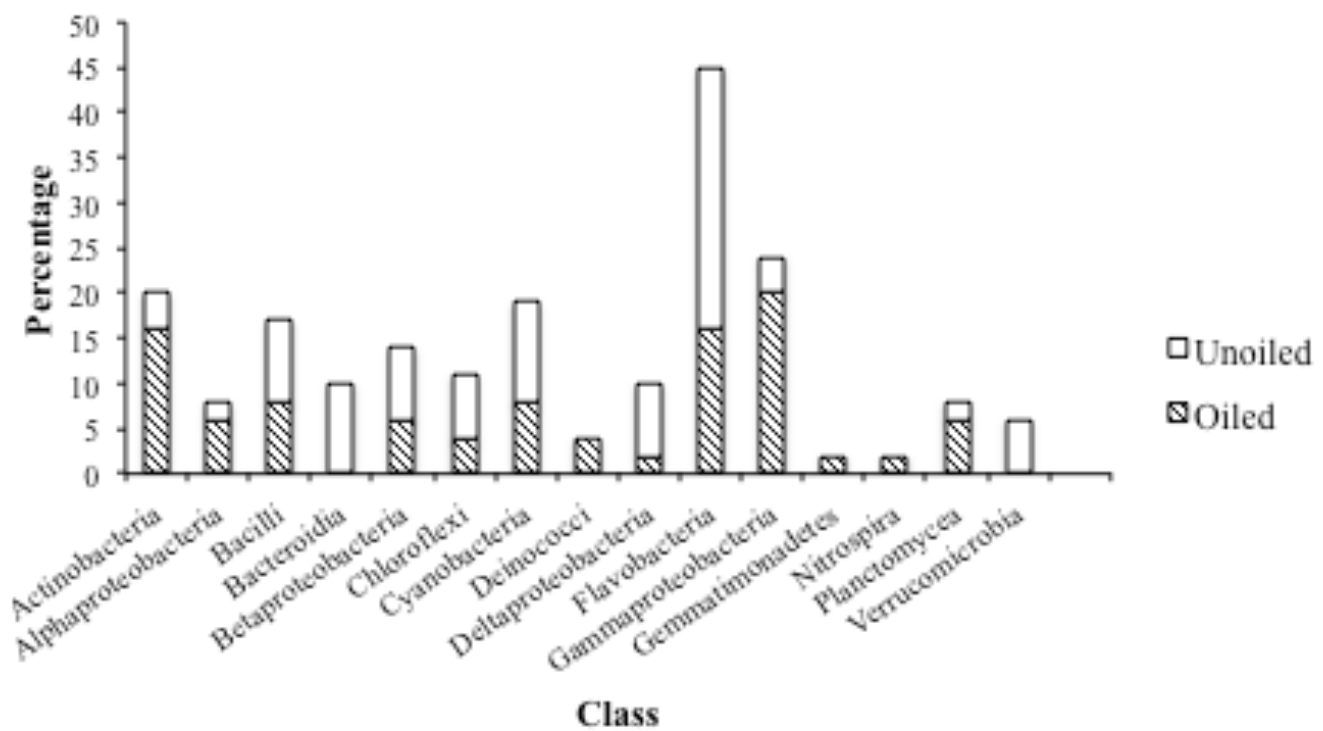

Fig. 4.2. A comparison of microbial communities from visibly oiled and unoiled beach sand samples based on 16S rRNA library. 16S rRNA gene library in Table A5 has more information on the kind of bacteria found in visibly oiled and unoiled sand samples.

\subsection{Effect of oil geometry on electron acceptor conditions}

Distinct differences were noted in DO (Fig. 4.3) and sulfate (Fig. 4.4) concentrations among the integrated column effluent samples, which were collected daily at the time of shifting from the high tide to the low tide condition. Notably, the effluent DO of the sheet columns was consistently lower than the tar columns, which was significantly lower than the blank columns. The differences in DO observed between the columns containing oil and the blank suggests that the oil exerted an oxygen demand, which further suggests bioavailability of the oil. 
Hydrocarbons were regularly monitored in the integrated effluent samples, but remained below detection for all column configurations (data not shown), consistent with rapid biodegradation of any oil that may have dissolved into the aqueous phase.

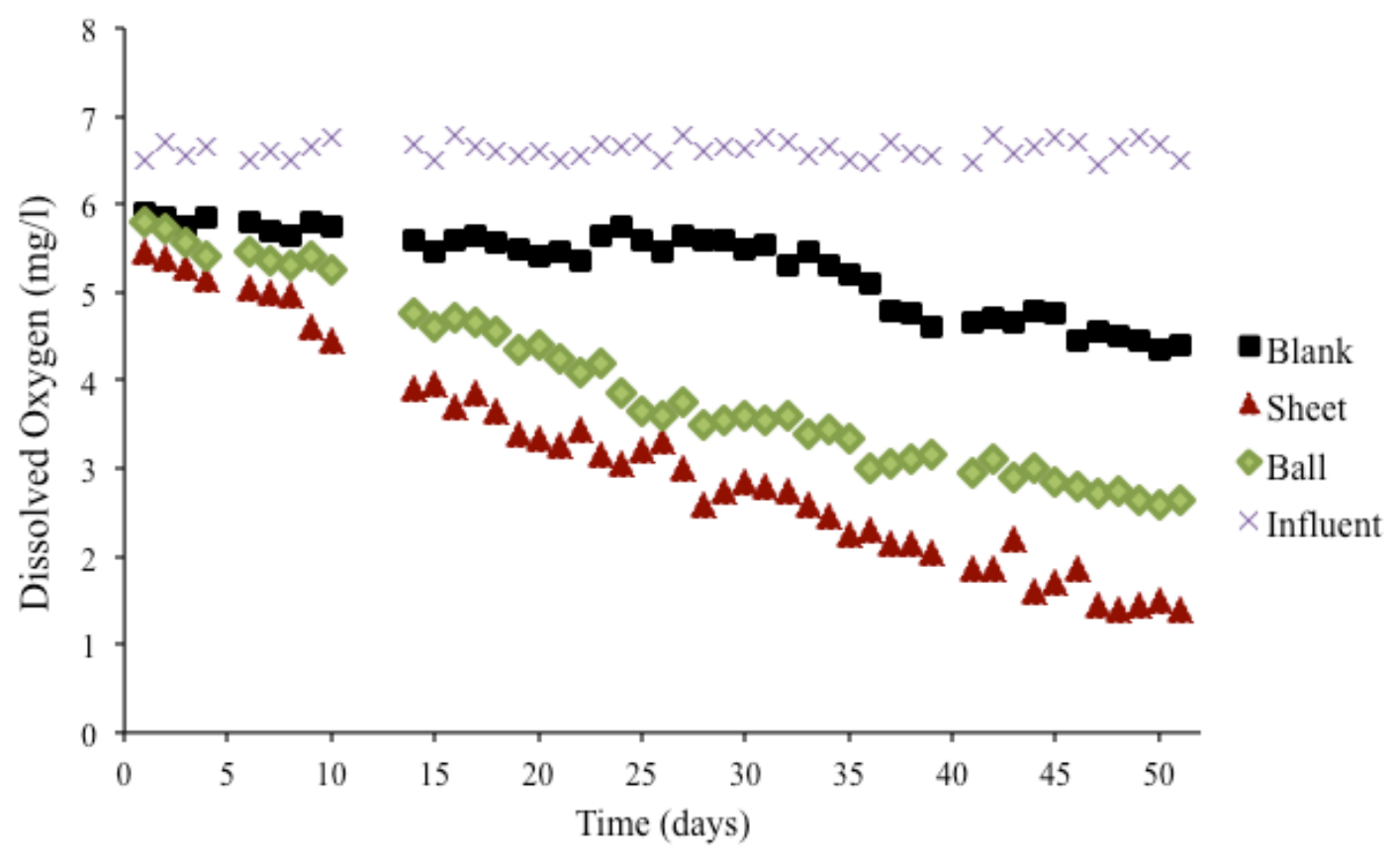

Fig. 4.3. Dissolved oxygen (DO) concentration in influent and integrated column effluents with time. DO values for ball columns represent the average of duplicates; the blank and sheet columns were single replicates. The slopes and intercept for a linear mixed model fit to the data with corAR1 as a correlation structure were significantly different among blank, sheet, and ball columns. 


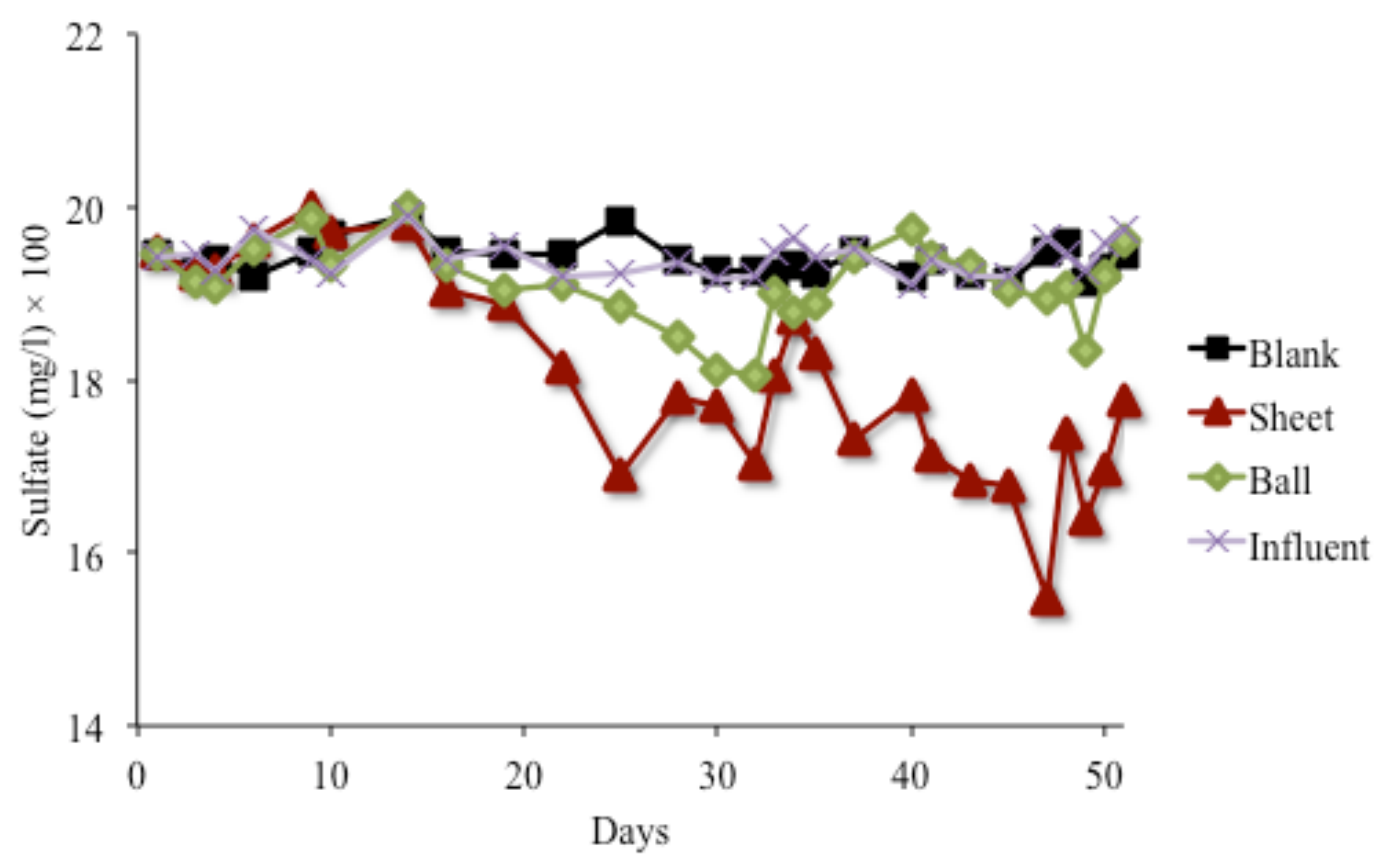

Fig. 4.4. Sulfate concentration the influent and integrated effluent of the columns with time. Sulfate concentrations for ball condition are the average of the duplicate columns, whereas for sheet and blank the data is for a single column. After 28 days significant differences were observed in the slope of the sheet column relative to the ball and blank columns according to linear mixed model fit to the data using corAR1.

Interestingly, the sulfate concentration was significantly lower in the integrated effluent collected from the sheet relative to the ball columns after $28^{\text {th }}$ day of operation $(\mathrm{p}<0.01)$ (Fig. 4.4). This suggests that sulfate reduction was established and occurred and to a greater extent in the sheet columns. The sulfate deficit observed in the sheet columns is consistent with the lower DO, further supporting the conclusion that sulfate reducing anaerobic zones are induced by the sheet geometry. This is a vital finding of this research considering that electron acceptor conditions were a major driver of microbial community composition. Each oil degrader enriched by the distinct geometries is in turn tied to a specific range of kinetic limitations, such as $\mu_{\max }$, Ks, and 
yield coefficients. Thus, the findings suggest that geometry may represent a more significant factor than previously thought in modeling the natural attenuation rates of shoreline petroleum deposits.

\subsection{Response of bacterial community to geometry}

A stark contrast in in DGGE fingerprints was noted across the three column types (Table 4.1, Fig. 4.5), indicating that the presence of oil, and its particular geometry, stimulated unique bacterial communities. Within each column condition the greatest contrasts among the column layers were observed in the sheet column (Table 4.1, Fig. 4.5). The ball condition appeared to induce only a slightly greater contrast with depth relative to the blank column according to Bray Curtis similarity analysis of the DGGE fingerprints (Table 4.1) and corresponding dendrograms (Fig. 4.6 - 4.8). Table A1 provides a summary of the bacteria identified based on DNA sequence analysis of DGGE bands, supporting the conclusion that anaerobic bacteria, some capable of hydrocarbon degradation, were induced by the sheet condition. Anaerobic and facultative microorganisms with highest DNA sequence similarity to Anaerophaga thermohalophila, Muricauda ruestringensis, Petrotoga spp., and DE Marinobacter hydrocarbonoclasticus, were identified in transect samples from the sheet column. Of these, A. thermohalophila and $M$. hydrocarbonoclasticus correspond to strains confirmed to degrade hydrocarbons under anaerobic conditions [86-88]. M. ruestringensis was previously found to be associated with an alkane degrading microbial community [89] and Petrotoga is an anaerobic genus indigenous to oil reservoirs [90]. A band in the sheet column was also found to have highest DNA sequence similarity to a PAH-degrading marine bacterium, Roseovarius sp. [91, 92]. In ball columns, none of the above bacteria could be identified by DGGE. However, bands with high sequence 
similarity to an anaerobic fermenter belonging to Leptolinea sp. and a facultative anaerobe Colwellia sp. SW2-3E $[93,94]$ suggested potentially low oxic zones in the columns. Due to a slow leak that developed in one of the duplicate sheet columns, molecular analysis was based only on the non-leaking column.

\begin{tabular}{c|c|cccc|}
\cline { 2 - 6 } & Section & $\mathbf{0 ~ c m}$ & $\mathbf{- 2 . 5} \mathbf{~ c m}$ & $\mathbf{- 5} \mathbf{~ c m}$ & $\mathbf{- 7 . 5 ~} \mathbf{~ c m}$ \\
\hline \multirow{5}{*}{ Blank } & $\mathbf{+ 2 . 5} \mathbf{~ c m}$ & 89.1 & 84.7 & 90.4 & 92.0 \\
& $\mathbf{0 ~ c m}$ & & 85.2 & 94.5 & 87.5 \\
& $\mathbf{- 2 . 5} \mathbf{~ c m}$ & & & 83.0 & 81.8 \\
& $\mathbf{- 5} \mathbf{~ c m}$ & & & & 82.1 \\
\cline { 2 - 6 } Ball $^{2}$ & $\mathbf{+ 2 . 5} \mathbf{~ c m}$ & $81.1 \pm 3.6$ & $82.3 \pm 3.5$ & $81 \pm 2.7$ & $88.1 \pm 1.9$ \\
& $\mathbf{0 ~ c m}$ & & $93.9 \pm 0.4$ & $91.5 \pm 4.6$ & $84.1 \pm 8.4$ \\
& $\mathbf{- 2 . 5} \mathbf{~ c m}$ & & & $92.6 \pm 0.9$ & $83.1 \pm 5.7$ \\
& $\mathbf{- 5} \mathbf{~ c m}$ & & & & $84.3 \pm 6.3$ \\
\cline { 2 - 6 } Sheet & $\mathbf{+ 2 . 5} \mathbf{~ c m}$ & 66.3 & 55.2 & 50.2 & 47.2 \\
& $\mathbf{0 ~ c m}$ & & 67.1 & 69.5 & 57.0 \\
& $\mathbf{- 2 . 5} \mathbf{~ c m}$ & & & 71.2 & 50.8 \\
& $\mathbf{- 5} \mathbf{~ c m}$ & & & & 68.5 \\
\hline
\end{tabular}

Table 4.1 Bray Curtis Similarity of DGGE banding patterns of sub-samples of column cores with depth, relative to the oil deposits ${ }^{1}$.

${ }^{1}$ calculated using Primer E [85] on square root transformed data.

${ }^{2}$ duplicate columns for ball condition, single columns for the other two conditions 


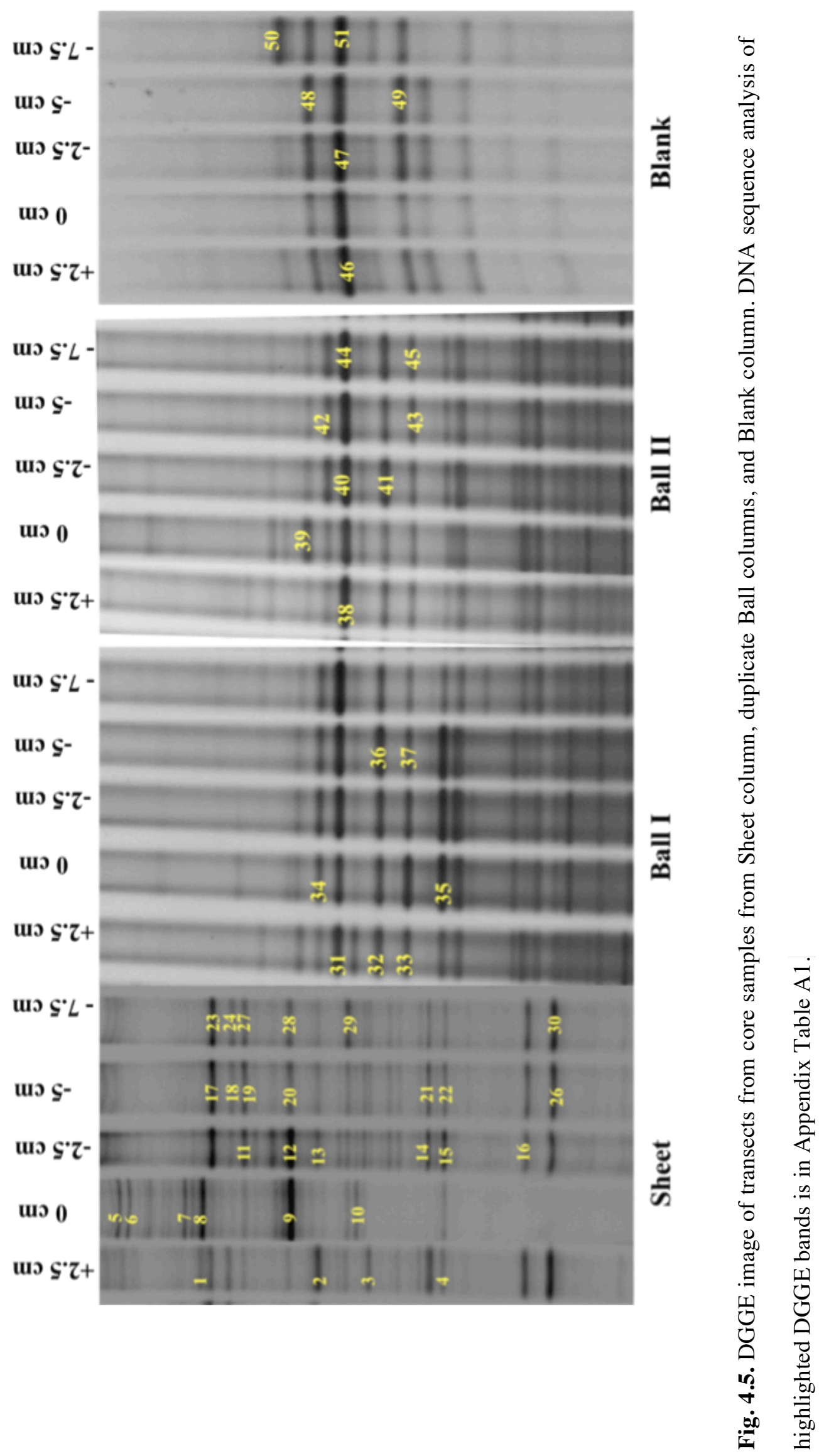




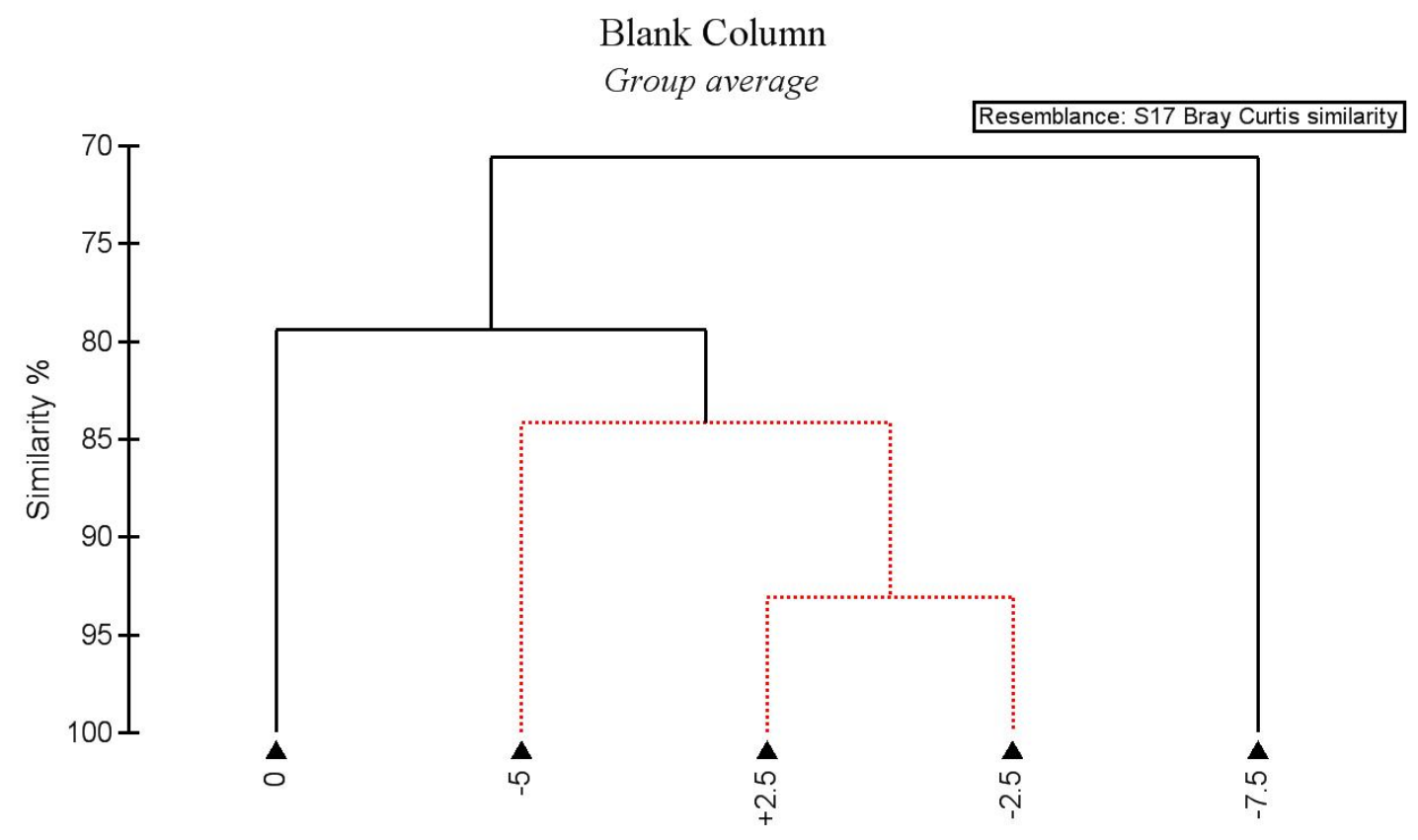

Fig. 4.6. Hierarchical cluster of the sub-samples with depth from blank column core. Depths correspond to those sub-sampled from oiled columns. Red dashed lines indicate that the difference between the clustered samples is not significant. $\mathrm{y}$-axis is indicative of Bray-Curtis similarity at which a cluster is formed. Hierarchical clustering was conducted using 'Group average' method [85]. 


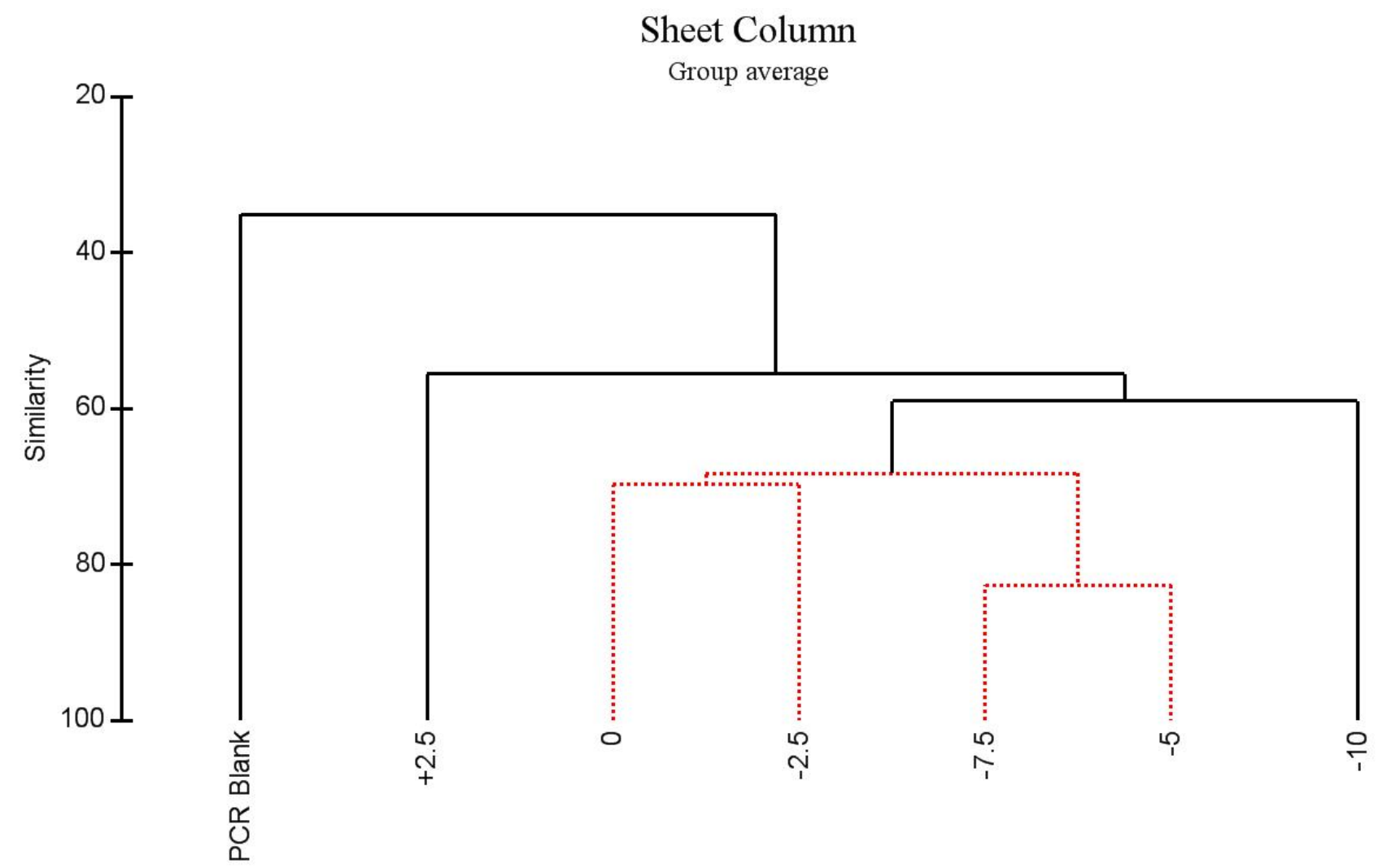

Fig. 4.7. Hierarchical cluster of the samples from the sheet column. Depths correspond to those subsampled from oiled columns. Red dashed lines indicate that the difference between the clustered samples is not significant. Y-axis is indicative of Bray-Curtis similarity at which a cluster is formed. Hierarchical clustering was conducted using 'Group average' method [85]. 


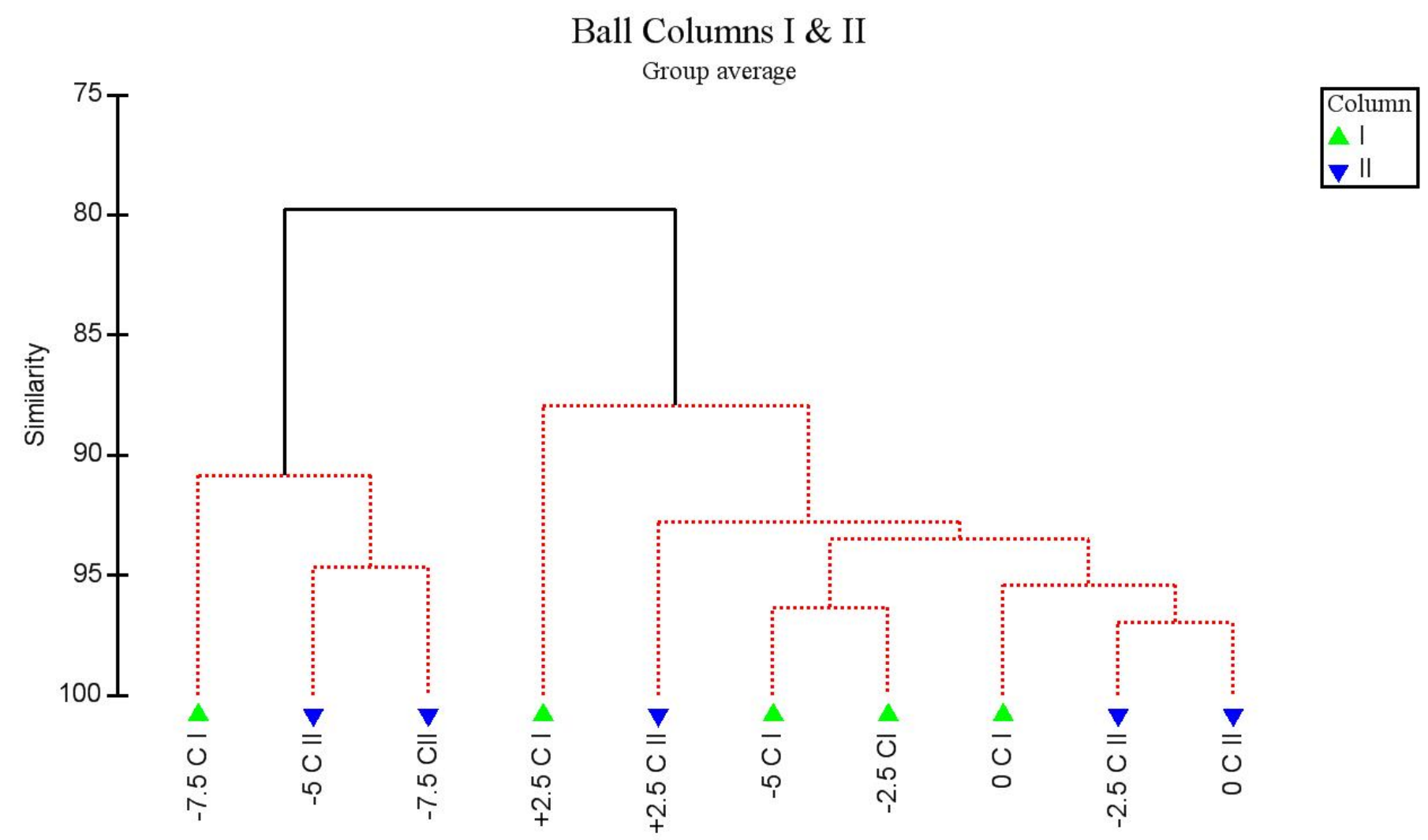

Figure 4.8. Hierarchical cluster of the samples from the duplicate ball columns. Depths correspond to those sub-sampled from oiled columns. Red dashed lines indicate that the difference between the clustered samples is not significant. Y-axis is indicative of Bray-Curtis similarity at which a cluster is formed. Hierarchical clustering was conducted using 'Group average' method [85].

\subsection{Effect of geometry on stratification of functional genes}

qPCR of $d s r \mathrm{~A}$ and $m c r \mathrm{~A}$ genes in column cores provided a quantitative snapshot of the impact of petroleum deposit geometry on microbial communities in terms of their response to the redox gradients formed. Notably, $d s r \mathrm{~A}$ and $m c r \mathrm{~A}$ genes were significantly higher immediately beneath petroleum deposits $(\mathrm{p}<0.02)$, relative to the blank columns, and were higher overall below the sheet than the ball deposits (Fig. 4.9). Given that methanogenesis and sulfate reduction are obligately anaerobic processes, these observations further corroborate the 
conclusion that anaerobic zones were stimulated by the presence of the oil deposits. Furthermore, the sheet geometry appeared to induce more pronounced anaerobic conditions than the ball, given that mcrA gene copies were highest in the sheet column $(\mathrm{p}<0.01)$. 16S rRNA genes were also quantified as an indicator of total bacterial biomass, levels of which were found to peak at the depth of the oil deposits in the ball columns, and just beneath in the sheet columns (Figure 4.8). 16S rRNA gene densities remained constant through the blank column transect. Analysis of functional genes involved in hydrocarbon degradation provides evidence of impact of hydrocarbon bioavailability by oil geometry. Considering that hydrocarbons possess extremely slow dissolution constants, it is assumed that oil was biodegraded as quickly as it entered the aqueous phase. Catechol- 2,3- dioxygenase (cat23) is a widely recognized intermediate for aerobic oxidation of aromatic compounds. cat 23 was found to be significantly higher in concentration in the ball columns $(\mathrm{p}<0.05)$ and were merely above the detection limit in blank columns $(\mathrm{p}<0.02)$. This suggests a greater extent of aerobic degradation of aromatic compounds in the ball relative to the sheet columns. 


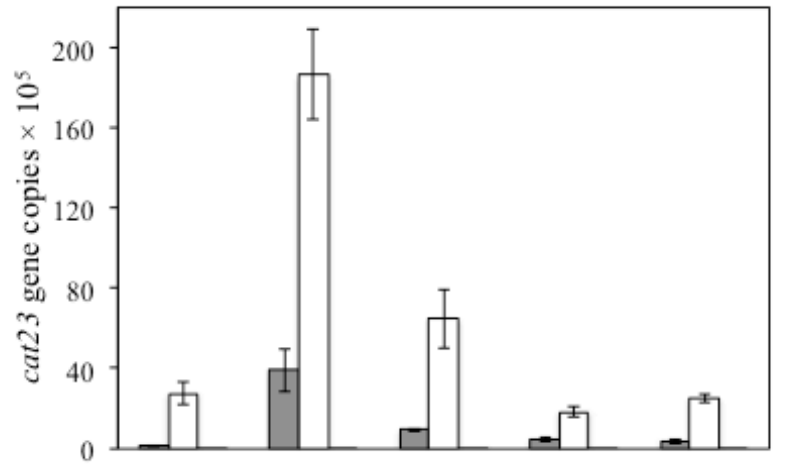

$\square$ Sheet

$\square$ Ball

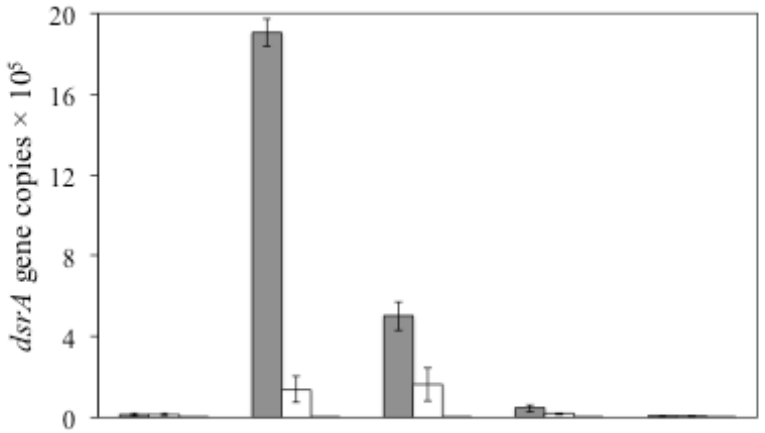

- Blank

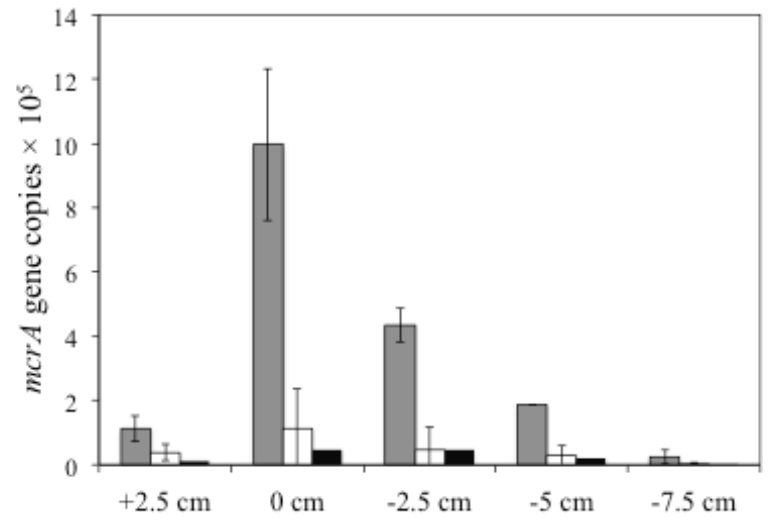

Fig. 4.9. Copies of $c a t 23, d s r A$, and $m c r A$ genes in 1 -g subsamples of column cores with depth, relative to the oil deposit. Data for ball condition represent the average of duplicate columns, the others are single columns. Error bars represent the standard deviation of triplicates for qPCR for each column core subsample. Significant differences with depth were confirmed for the ball and sheet columns according to the Friedman rank sum test (p-values ranging from 0.007-0.015). Differences among ball, sheet, and blank conditions were significant at any given depth (p-values ranging from 0.002-0.043). An autocorrelation test acf confirmed no significant autocorrelation within the same column $(\operatorname{acf}<0.05)$. 


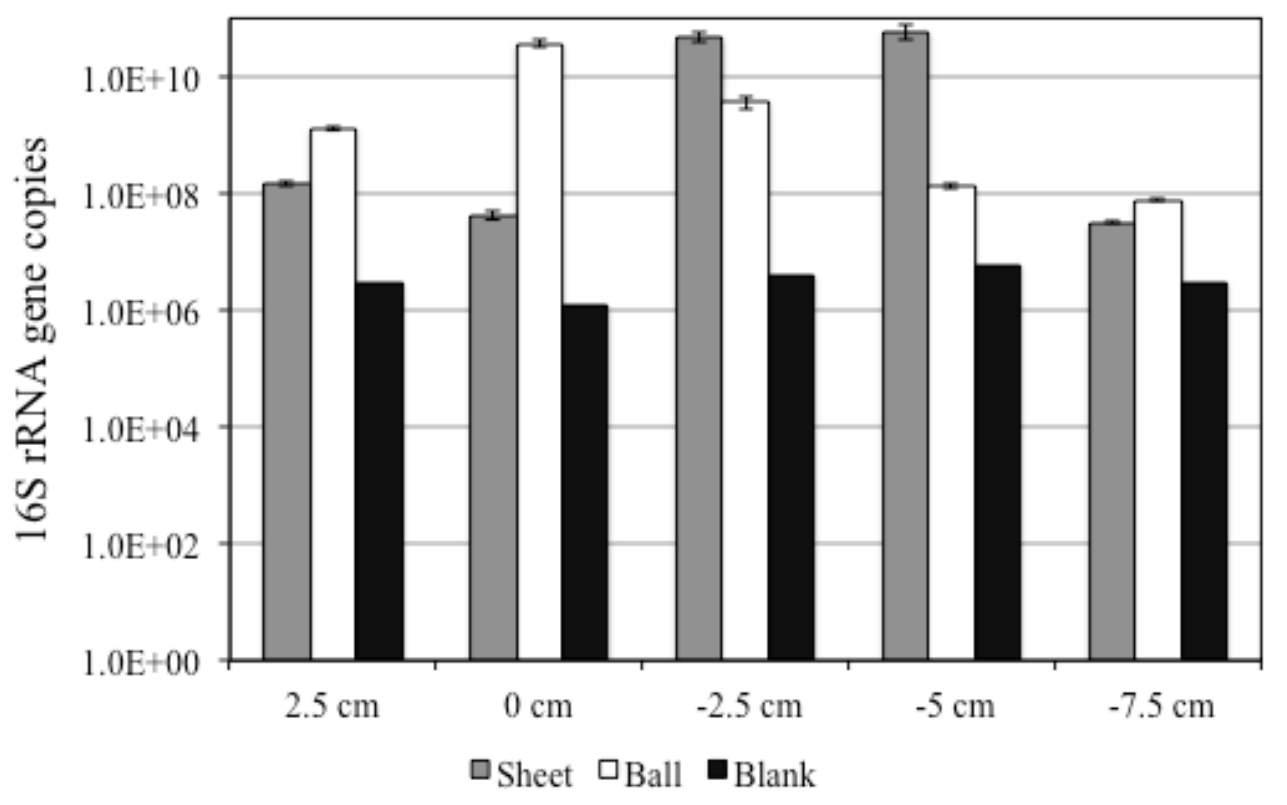

Fig. 4.10. 16S rRNA gene copies per gram of sub-sample of column cores with depth. Data for ball columns is average of duplicate columns. Error bars represent the standard deviation of triplicate qPCR measurements of each sample.

\subsection{Implications}

In coastal settings the predominant source of nutrient replenishment for buried petroleum deposits is induced by the tidal rise and fall of groundwater and rainfall-recharge events. In such situations, petroleum deposits may pose as a hydrophobic obstruction to the flux of nutrients and electron acceptors. The results of this study suggest that deposits that are spread out horizontally into sheets of petroleum obstruct recharge to a greater extent than tar balls. The sheet geometry resists natural attenuation by at least two factors: lower surface area to volume ratio, and higher obstruction to flow. This further limits the biodegradation rate of sheet deposit of petroleum and enhances their persistence. Thus, tar sheets may be a greater priority for cleanup than tar balls. This is a significant finding given the tremendous amount of time, resources, and human capital 
expended in removing tiny tar balls from the beaches following the Deepwater Horizon spill. Further, this aggressive action may have resulted in a negative impact on the local ecosystem by removing too much organic matter and disrupting the habitat of nesting birds [58, 95-97].

This study provides proof of concept of the effect of petroleum deposit geometry on local redox and microbial community gradients and highlights the need to more closely examine the role of geometry as a governing factor in the natural attenuation of oil spills. Future studies may be of interest that extend the approach to scenarios where recharge occurs from beneath the oil deposit via groundwater, rather than from the top via rising tide, as simulated in this study. In the bottom-filling scenario, the redox gradient might not be as extreme as observed in this study, but still would be anticipated based on the relatively stagnant intertidal condition. Given the distinct bioavailabilities and that microbes corresponding to different redox conditions possess vastly different biodegradation capabilities and metabolic rates $[19,34,35,38]$, petroleum deposit geometry could represent a critical factor governing the overall natural attenuation rate of coastal oil spills. 


\section{Chapter 5. Conclusions}

\subsection{Summary:}

In order to understand the potential role of geometry of petroleum deposits in dictating local redox conditions around the deposit, sand columns were set up with two different deposits of contrasting geometries: ball and sheet. The balls and sheet deposits used in this study have similar chemical composition and were designed in such a way that mass of oil was same in both types of columns. The ball shaped deposit is representative of the tar balls, which were observed in high number on coasts after DWH oil spill, whereas the sheet is representative of the oil layers and shallow lakes of oil, which often develop on coasts following a heavy contamination by an oil spill. The columns were operated and compared to a column with no oil deposit on basis of the DO and sulfate of the integrated effluent collected on a daily basis. It was observed that the sheet geometry encouraged establishment of a more anaerobic environment in the column and resulted in significant sulfate reduction.

Sacrificing the sand columns provided an opportunity to gain a sneak peek into microbial colonization of the column. The columns were operated as 1D sand columns and therefore microbial community was characterized on basis of single dimension of depth. Depth wise analysis was conducted using molecular tools: DGGE and qPCR of biomarker genes. This depth wise microbial analysis provided substantial evidence in support of dramatic changes in microbial community in sheet column with depth. This was contrasted with comparatively similar microbial communities in columns with balls and no oil control. Evidence for development of anaerobic zone below the sheet deposit was provided by qPCR of key biomarker genes: $\operatorname{dsr} A, \operatorname{mcr} A$, cat23. Again, dramatic development of anaerobic conditions below the sheet deposit was observed, and in contrast, ball and no oil control columns hardly had anaerobic 
conditions. Establishment of methanogenic conditions below the sheet deposit indicates depletion of TEAs. This indicates rapid development of anaerobic zones under sheet deposit to allow all TEAs to be reduced anaerobically.

These observations suggest that sheet shaped deposit in the column encouraged development of anaerobic zones, unlike ball deposits. This is an evidence in support of the potential role of geometry in enforcing redox conditions around it in coastal settings. Geometry of petroleum deposits on coastal environments is suggested as an important factor in prediction of redox conditions around a deposit and kinetics of deposit biodegradation. It could prove a useful factor for fine-tuning models to predict long-term fate and persistence of petroleum deposits.

\subsection{Scope for Future Studies}

This study provides proof of concept that the petroleum deposit geometry has significant effect on local redox and microbial community gradients and highlights the need to more closely examine the role of geometry as a governing factor in the natural attenuation of oil spills. Future studies may be of interest that extend this approach to scenarios where recharge occurs from beneath the oil deposit via groundwater, rather than from the top via rising tide, as simulated in this study. In the bottom-filling scenario, the redox gradient might not be as extreme as observed in this study, but still would be anticipated based on the relatively stagnant intertidal condition. Given that microbes corresponding to different redox conditions possess vastly different biodegradation capabilities and metabolic rates [34, 35, 65, 98], petroleum deposit geometry could represent a critical factor governing the overall natural attenuation rate of coastal oil spills. Further, studies simulating mainland conditions will throw light on role of geometry of 
petroleum deposits in contaminated land regions where there are no tide conditions, and in arid regions with no recharge media, will help in predicting fate in inland petroleum contamination. Another aspect of this research, which can be further investigated, is dissolution characteristics of multicomponent petroleum hydrocarbons under influence of biodegradation and tidal conditions. Experimental information on dissolution characteristics will be useful for existing models [74], however it is difficult to determine experimentally because of quick onset of biodegradation, which quickly degrades any petroleum hydrocarbon in dissolved phase. It will be interesting to understand the dissolution rates and dissolution limit of different components of hydrocarbons, when present together in a complex mixture as found in natural reservoirs [43] and compare it to the values used in existing groundwater flow models.

\section{Dissolved Phase}

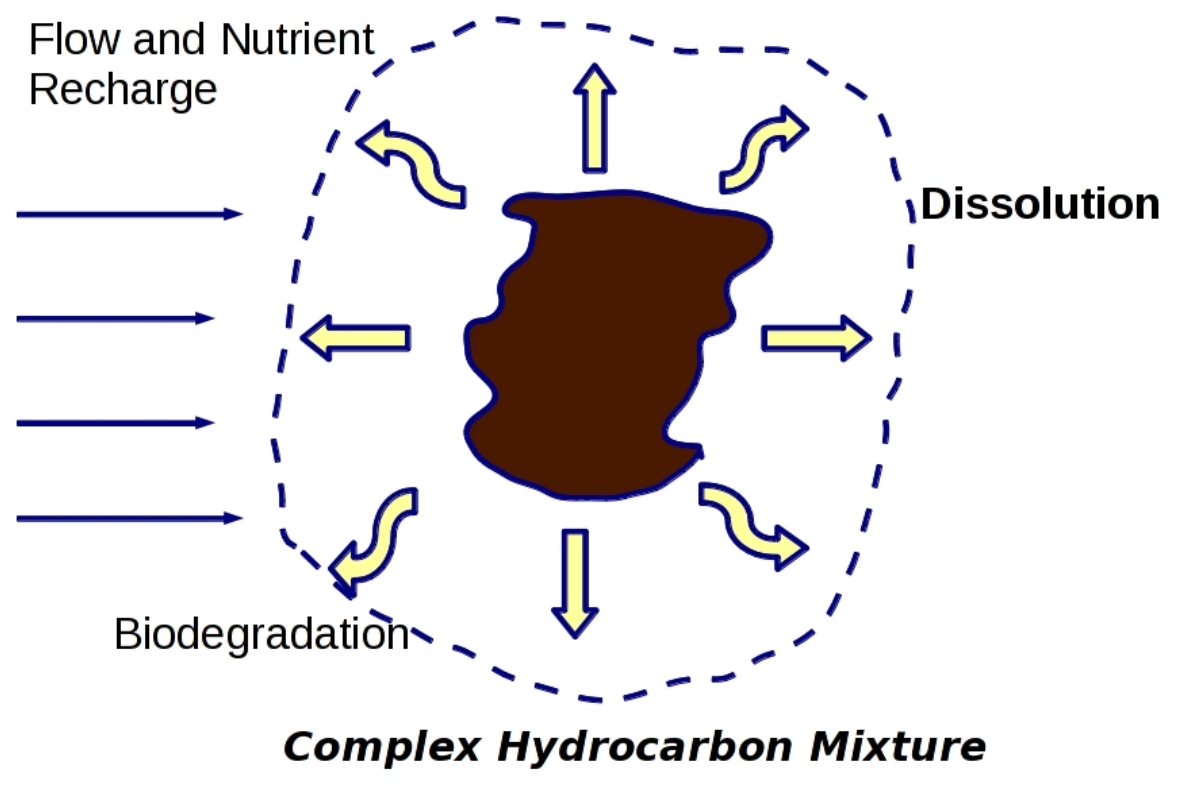

Fig. 5.1. Schematic summarizing nutrient recharge, biodegradation, and dissolution for hydrophobic hydrocarbons 


\section{References}

1. Diffley, J.; Bonakdarpour, M.; Norton, S.; Rosbash, T.; Fullenbaum, R.; O'Neil, B. The Economic Impacts of the Gulf of Mexico Offshore Oil and Natural Gas Industrry and the Role of the Independents; IHS Global Insight (USA), INC. : Lexington, MA, 2010.

2. Boland, G. Oil and Gas Exploration. http://oceanexplorer.noaa.gov/explorations/06mexico/background/oil/oil.html

3. Atlas, R. M.; Hazen, T. C., Oil Biodegradation and Bioremediation: A Tale of the Two Worst Spills in U.S. History. Environ. Sci. Technol. 2011, 45, 6709-6715.

4. Kornacki, A. S.; Kendrick, J. W.; Berry, J. L., Impact of oil and gas vents and slicks on petroleum exploration in the deepwater Gulf of Mexico. Geo-Marine Letters 1994, 14, 160-169.

5. Jernelov, A., The threats from Oil Spills: Now, Then, and in the Future. In Ambio, Royal Swedish Academy of Science: 2010; Vol. 39, pp 353-366.

6. NYSE: RIG Deepwater Horizon Drills World's Deepest Oil \& Gas Well

7. Graham, B.; Reilly, W. K.; Beinecke, F.; Boesch, D. F.; Garcia, T. D.; Murray, C. A.; Ulmer, F., Deepwater: The Gulf Oil Disaster and the Future of Offshore Drilling. In Report to the President, National Commission on the BP Deepwater Horizon Oil Spill and Offshore Drilling, Ed. January 2011.

8. Richard Camilli, D. D. L., Andrew Bowen, Christopher M. Reddy, Alexandra H. Techet, Dana R. Yoerger, Louis L. Whitcomb, Jeffrey S. Seewald, Sean P. Sylva, Judith Fenwick, Acoustic measurement of the Deepwater Horizon Macondo well flow rate. Proceedings of the National Academy of Sciences 2011.

9. National Oceanic and Atmospheric Administration http://oceanexplorer.noaa.gov/explorations/06mexico/background/oil/media/platform_600.html 10. Crawford, T. G.; Burgess, G. L.; Haley, S. M.; Harrison, P. F.; Kinler, C. J.; Klocek, G. D.; Shepar, N. K. Estimated Oil and Gas Reserves Gulf of Mexico; U.S. Department of the Interior Minerals Management Service Gulf of Mexico OCS Regional Office: New Orleans, 2006.

11. Prince, R. C., Bioremediation of Marine Oil Spills. In Handbook of Hydrocarbon and Lipid Microbiology, K. N. Timmis, Ed. C Springer-Verlag Berlin Heidelberg, 2010. 
12. Haines, J. R.; Kleiner, E. J.; McClellan, K. A.; Koran, K. M.; Holder, E. L.; King, D. W.; Venosa, A. D., Laboratory evaluation of oil spill bioremediation products in salt and freshwater system. J. Ind. Microbiol. Biotechnol. 2005, 32, 171-185.

13. Boufadel, M. C.; Sharifi, Y.; Aken, B. V.; Wrenn, B. A.; Lee, K., Nutrient and Oxygen Concentrations within the Sediments of an Alaskan Beach Polluted with the Exxon Valdez Oil Spill. Environ. Sci. Technol. 2010, 44, (19), 7418-7424.

14. Kostka, J. E.; Prakash, O.; Overholt, W. A.; Green, S. J.; Freyer, G.; Canion, A.; Delgardio, J.; Norton, A.; Hazen, T. C.; Huettel, M., Hydrocarbon-Degrading Bacteria and the Bacterial Community Response in Gulf of Mexico Beach Sands Impacted by the Deepwater Horizon Oil Spill. Applied and environmental microbiology 2011, 77, (22), 7962-7974.

15. Assessment of Flow Estimates for the Deepwater Horizon / Macondo Well Oil Spill; Flow Rate Technical Group Report to the National Incident Command. In Department of the Interior, Ed. Washington, DC, 2011.

16. Jefferson, J.; Bowling, N. The Economic and Biological Impacts of The BP Oil Spill; Hampden-Sydney College: 2011.

17. Kujawinski, E. B.; Soule, M. C. K.; Valentine, D. L.; Boysen, A. K.; Longnecker, K.; Redmond, M. C., Fate of Dispersants Associated with the Deepwater Horizon Oil Spill. Environ. Sci. Technol. 2010.

18. Deep Water. In The Gulf Oil Disaster and the Future of Offshore Drilling, Drilling, N. C. o. t. B. D. H. O. a. O., Ed. 2011.

19. Widdel, F.; Musat, F., Energetic and Other Quantitative Aspects of Microbial Hydrocarbon Utilization. In Handbook of Hydrocarbon and Lipid Microbiology, Timmis, K. N., Ed. (C) Springer-Verlag Berlin Heidelberg, 2010.

20. Huesemann, M. H.; Hausmann, T. S.; Fortman, T. J., Assessment of bioavailability limitations during slurry biodegradation of petroleum hydrocarbons in aged soils. Environ. Toxicol. Chem. 2003, 22, (12), 2853-2860.

21. Venosa, A. D.; Zhu, X. Q., Biodegradation of crude oil contaminating marine shorelines and freshwater wetlands. Spill Sci. Technol. Bull. 2003, 8, (2), 163-178.

22. Reddy, C. M.; Eglinton, T. I.; Hounshell, A.; White, H. K.; Xu, L.; Gaines, R. B.; Frysinger, G. S., The west falmouth oil spill after thirty years: The persistence of petroleum hydrocarbons in marsh Sediments. Environ. Sci. Technol. 2002, 36, (22), 4754-4760. 
23. Delaune, R. D.; Gambrell, R. P.; Pardue, J. H.; Patrick, W. H., Fate of PetroleumHydrocarbons and Toxic Organics in Louisiana Coastal Environments. Estuaries 1990, 13, (1), $72-80$.

24. Chapelle, F. H.; McMohan, P. B.; Dubrovsky, N. M.; Fujii, R. F.; Oaksford, E. T.; Vroblesky, D. A., Deducing the distribution of terminal electron-accepting processes in hydrologically diverse groundwater systems. Water Resour. Res. 1995, 31, (2), 359-371.

25. Imhoff, P. T.; Jaffe, P. R., Effect of Liquid Distribution on Gas-Water Phase MassTransfer in an Unsaturated Sand During Infiltration. J. Contam. Hydrol. 1994, 16, (4), 359-380.

26. Christ, J. A.; Ramsburg, C. A.; Pennell, K. D.; Abriola, L. M., Estimating mass discharge from dense nonaqueous phase liquid source zones using upscaled mass transfer coefficients: An evaluation using multiphase numerical simulations. Water Resour. Res. 2006, 42, (11).

27. Parker, J. C.; Park, E., Modeling field-scale dense nonaqueous phase liquid dissolution kinetics in heterogeneous aquifers. Water Resour. Res. 2004, 40, (5).

28. Hosseini, A. H.; Deutsch, C. V.; Mendoza, C. A.; Biggar, K. W., Inverse modeling for characterization of uncertainty in transport parameters under uncertainty of source geometry in heterogeneous aquifers. J. Hydrol. 2011, 405, (3-4), 402-416.

29. Widdowson, M. A., Modeling natural attenuation of chlorinated ethenes under spatially varying redox conditions. Biodegradation 2004, 15, (6), 435-451.

30. Ewing, R. P.; Berkowitz, B., A generalized growth model for simulating initial migration of dense non-aqueous phase liquids. Water Resour. Res. 1998, 34, (4), 611-622.

31. Ramsay, M. A.; Swannell, R. P. J.; Shipton, W. A.; Duke, N. C.; Hill, R. T., Effect of bioremediation on the microbial community in oiled mangrove sediments. Mar. Pollut. Bull. 2000, 41, (7-12), 413-419.

32. Prince, R. C.; Bare, R. E.; Garrett, R. M.; Grossman, M. J.; Haith, C. E.; Keim, L. G.; Lee, K.; Holtom, G. J.; Lambert, P.; Sergy, G. A.; Owens, E. H.; Guenette, C. C., Bioremediation of stranded oil on an Arctic shoreline. Spill Sci. Technol. Bull. 2003, 8, (3), 303312.

33. Tiehm, A.; Schulze, S., Intrinsic aromatic hydrocarbon biodegradation for groundwater remediation. Oil Gas Sci. Technol. 2003, 58, (4), 449-462. 
34. Lu, J.; Jin, Q.; He, Y. L.; Wu, J., Enhanced anaerobic biodegradation of nonylphenol ethoxylates by introducing additional sulfate or nitrate as terminal electron acceptors. Int. Biodeterior. Biodegrad. 2008, 62, (2), 214-217.

35. Schreiber, M. E.; Carey, G. R.; Feinstein, D. T.; Bahr, J. M., Mechanisms of electron acceptor utilization: implications for simulating anaerobic biodegradation. J. Contam. Hydrol. 2004, 73, (1-4), 99-127.

36. Abed, R. M. M.; Musat, N.; Musat, F.; Mu $\beta$ mann, M., Structure of microbial communities ad hydrocarbon-dependent sulfate reduction in the anoxic layer of a polluted mat. Mar. Pollut. Bull. 2011, 62, 539-546.

37. Amos, B. K.; Suchomel, E. J.; Pennell, K. D.; Loffler, F. E., Microbial activity and distribution during enhanced contaminant dissolution from a NAPL source zone. Water Res. 2008, 42, (12), 2963-2974.

38. Jones, D. M.; Head, I. M.; Gray, N. D.; Adams, J. J.; Rowan, A. K.; Aitken, C. M.; Bennett, B.; Huang, H.; Brown, A.; Bowler, B. F. J.; Oldenburg, T.; Erdmann, M.; Larter, S. R., Crude-oil biodegradation via methanogenesis in subsurface petroleum reservoirs. Nature 2008, 451 .

39. Pereyra, L. P.; Hiibel, S. R.; Prieto Riquelme, M. V.; Reardon, K. F.; Pruden, A., Detection and quantification of functional genes of cellulose- degrading, fermentative, and sulfate-reducing bacteria and methanogenic archaea. Appl. Environ. Microbiol. 2010, 76, (7), 2192-202.

40. Baek, K.-H.; Yoon, B.-D.; Cho, D.-H.; Kim, B.-H.; Oh, H.-M.; Kim, H.-S., Monitoring Bacterial Population Dynamics using Real-Time PCR During the Bioremediation of Crude-OilContaminated Soil. J. Microbiol. Biotechnol. 2009, 19, (4), 6.

41. Rahimi, P. M.; Gentzis, T., The Chemistry of Bitumen and Heavy Oil Processing. In.

42. U.S. Congress, Bioremediation for Marine Oil Spills - Background Paper, OTA-BP-O-70 In Office of Technology Assessment, Ed. U.S. Government Printing Office: Washington, DC, 1991.

43. Wang, Z.; Hollebone, B. P.; Fingas, M.; Fieldhouse, B.; Sigouin, L.; Landriault, M.; Smith, P.; Noonan, J.; Thouin, G.; Weaver, J. W. Composition and Properties of Selected Oils; EPA/600/R-03/072; National Exposure Research Laboratory, Office of Research and 
Development, United States Environmental Protection Agency: Research Triangle Park, North Carolina, 2003.

44. Venosa, A. D.; Campo, P.; Suidan, M. T., Biodegradability of Lingering Crude Oil 19 Years after the Exxon Valdez Oil Spill. Environ. Sci. Technol. 2010, 44, 7613-7621.

45. Pérez-Pantoja, D.; González, B.; Pieper, D. H., Aerobic Degradation of Aromatic Hydrocarbons. 2010, 799-837.

46. Monserrate, E.; Haggblom, M. M., Dehalogenation and biodegradation of brominated phenols and benzoic acids under iron-reducing, sulfidogenic, and methanogenic conditions. Appl. Environ. Microbiol. 1997, 63, (10), 3911-3915.

47. Suflita, J. M., Detection of Anaerobic Metabolites of Saturated and Aromatic Hydrocarbons in Petroleum-Contaminated Aquifers. Environ. Sci. Technol. 2002, 36, (17), 37553762 .

48. Overton, E. B.; Ashton, B. M.; Miles, M. S., Historical polycyclic aromatic and petrogenic hydrocarbon loading in Northern Central Gulf of Mexico shelf sediments. Mar. Pollut. Bull. 2004, 49, 557-563.

49. National Research Council Oil in the Sea III: Inputs, Fates and Effects.; Washington DC, 2002.

50. Vroblesky, D. A.; Chapelle, F. H., Temporal and spatial chages of terminal electronaccepting processes in a petroleum hydrocarbon-contaminated aquifer and the significance for contaminant biodegradation. Water Resour. Res. 1994, 15, 1479-1498.

51. Whyte, L. G.; Schultz, A.; van Beilen, J. B.; Luz, A. P.; Pellizari, V.; Labbe, D.; Greer, C. W., Prevalence of alkane monooxygenase genes in Arctic and Antarctic hydrocarboncontaminated and pristine soils. FEMS Microbiol. Ecol. 2002, 41, 141-150.

52. Boll, M.; Heider, J., Anaerobic Degradation of Hydrocarbons: Mechanisms of C-H-Bond Activation in the Absence of Oxygen. In Handbook of Hydrocarbon and Lipid Microbiology, Timmis, K. N., Ed. Springer-Verlag: Berlin Heidelberg, 2010; pp 1011-1024.

53. Gieg, L. M.; Davidova, I. A.; Duncan, K. E.; Suflita, J. M., Methanogensis, sulfate reduction and crude oil biodegradation in hot Alaskan oilfields. Environmental Microbiology 2010, 12, (11), 3074-3086. 
54. Pérez-Pantoja, D.; González, B.; Pieper, D. H., Aerobic Degradation of Aromatic Hydrocarbons. In Handbook of Hydrocarbon and Lipid Microbiology, Timmis, K. N., Ed. Springer-Verlag: Berlin Heidelberg, 2010.

55. Diercks, A. R.; Highsmith, R. C.; Asper, V. L.; Joung, D. J.; Zhou, Z. Z.; Guo, L. D.; Shiller, A. M.; Joye, S. B.; Teske, A. P.; Guinasso, N.; Wade, T. L.; Lohrenz, S. E., Characterization of subsurface polycyclic aromatic hydrocarbons at the Deepwater Horizon site. Geophys. Res. Lett. $2010,37$.

56. Hazen, T. C., Deep-Sea Oil Plume Enriches Indigenous Oil-Degrading Bacteria. Science 2010, 330, 5 .

57. Camilli, R.; Reddy, C. M.; Yoerger, D. R.; Van Mooy, B. A. S.; Jakuba, M. V.; Kinsey, J. C.; McIntyre, C. P.; Sylva, S. P.; Maloney, J. V., Tracking Hydrocarbon Plume Transport and Biodegradation at Deepwater Horizon. Science 2010, 330, (6001), 201-204.

58. Rogers, J. DI Sea Lab: Leave tar balls on beach. http://www.fox10tv.com/dpp/news/gulf_oil_spill/di-sea-lab-leave-tar-

59. Brussaard, C. P. D.; Peperzak, L.; Witte, Y.; Huisman, J., An Experimental Oil Spill at Sea. In Handbook of Hydrocarbon and Lipid Microbiology, K. N. Timmis (ed.), Ed. SpringerVerlag: Berlin Heidelberg, 2010; pp 3491-3502.

60. Fetzner, S., Aerobic Degradation of Halogenated Aliphatics. 2010, 865-885.

61. Schinner, F., Biodegradation and bioremediation of hydrocarbons in extreme environments. Applied microbiology and biotechnology 2001, 56, (5-6), 650-663.

62. Schaefer, C. E.; Condee, C. W.; Vainberg, S.; Steffan, R. J., Bioaugmentation for chlorinated ethenes using Dehalococcoides sp.: Comparison between batch and column experiments. Chemosphere 2009, 75, (2), 141-148.

63. Widdel, F.; Knittel, K.; Galushko, A., Anaerobic Hydrocarbon-Degrading Microorganisms: An Overview. 2010, 1997-2021.

64. Planckaert, M., Oil Reservoirs and Oil Production. In Petroleum Micrbobiology, Ollivier, B.; Magot, M., Eds. American Society for Microbiology: Washington, D.C., 2005.

65. Jakobsen, R., Redox microniches in groundwater: A model study on the geometric and kinetic conditions required for concomitant $\mathrm{Fe}$ oxide reduction, sulfate reduction, and methanogenesis. Water Resour. Res. 2007, 43, (W12S12). 
66. Taylor, B. F.; Campbell, W. 1.; Chinoy, I., Anaerobic Degradation of the Benzene Nucleus by a Facultatively Anaerobic Microorganism. J. Bacteriol. 1970, 102, (2), 430-437.

67. Thauer, R. K., Biochemistry of methanogenesis: a tribute to Marjory Stephenson. Microbiology 1998, 144, (2377-2406).

68. Hallam, S. J.; Girguis, P. R.; Preston, C. M.; Richardson, P. M.; DeLong, E. F., Identification of Methyl Coenzyme M Reductase A (mcrA) Genes Associated with MethaneOxidizing Archaea. Applied and environmental microbiology 2003, 69, (9), 5483-5491.

69. Beller, H. R.; Kane, S. R.; Legler, T. C.; Alvarez, P. J. J., A Real-Time Polymerase Chain Reaction Method for Monitoring Anaerobic, Hydrocarbon-Degrading Bacteria on a Catabolic Gene. Environ. Sci. Technol. 2002, 36, (18), 3977-3984.

70. Hiibel, S. R.; Pruden, A.; Reardon, K. F., Comparison of microbial community composition and activity in sulfate-reducing batch systems remediating mine drainage. Biotechnology and bioengineering 2008, 101, (4), 702-713.

71. Mesarch, M. B.; Nakatsu, C. H.; Nies, L., Development of Catechol 2,3-DioxygenaseSpecific Primers for Monitoring Bioremediation by Competitive Quantitative PCR. Applied and Environmental Microbiology 2000, 66, (2), 678-683.

72. Waddill, D. W.; Widdowson, M. A., Three-dimensional model for subsurface transport and biodegradation. J. Environ. Eng.-ASCE 1998, 124, (4), 336-344.

73. Brauner, J. S.; Widdowson, M. A., Numerical simulation of a natural attenuation experiment with a petroleum hydrocarbon NAPL source. Ground Water 2001, 39, (6), 939-952.

74. Essaid, H. I.; Cozzarelli, I. M.; Eganhouse, R. P.; Herkelrath, W. N.; Bekins, B. A.; Delin, G. N., Inverse modeling of BTEX dissolution and biodegradation at the Bemidji, MN crude-oil spill site. Contaminant Hydrology 2003, 67, 269-299.

75. Essaid, H. I.; Bekins, B. A.; Godsy, E. M.; Warren, E.; Baedeckerand, M. J.; Cozzarelli, I. M., Simulation of aerobic and anaerobic biodegradation processes at a crude oil spill site. Water Resour. Res. 1995, 31, (12), 3309-3327.

76. Google Earth 6. earth.google.com

77. Camoes, M. F.; Oliveira, C.; Silva, M. C. R., Ionic composition of seawaters and derived saline solutions determined by ion chromatography and its relation to other water quality parameters. Journal of chromatography 2008, 1210, (1), 92-98. 
78. Weisburg, W. G.; Barns, S. M.; Pelletier, D. A.; Lane, D. J., 16S Ribosomal DNA Amplification for Phylogenetic Study. J. Bacteriol. 1991, 173, (2), 697-703.

79. Watanbe, K.; Kodama, Y.; Harayama, S., Design and evaluation of PCR primers to amplify bacterial 16S ribosomal DNA fragments used for community fingerprinting. $J$. Microbiol. Methods 2001, (44), 10.

80. Basic Local Alignment Search Tool. http://blast.ncbi.nlm.nih.gov/Blast.cgi

81. R Development Core Team (2011). R: A language and environment for statistical computing. R Foundation for Statistical Computing, Vienna, Austria. ISBN 3-900051-07-0, URL http://www.R-project.org/. In.

82. Clarke, K. R.; Gorley, R. N., PRIMER v6: User Manual/Tutorial. PRIMER-E, Plymouth. 2006.

83. Nordhausen, K.; Sirkia, S.; Oja, H.; Tyler, D. E. ICSNP: Tools for Multivariate Nonparametrics. R package version 1.0-7. http://CRAN.R-project.org/package=ICSNP

84. Pinheiro, J.; Bates, D.; DebRoy, S.; Sarkar, D., and the R Development Core Team (2011). nlme: Linear and Nonlinear Mixed Effects Models. R package version 3.1-102. In.

85. Clarke, K. R., Non-parametric multivariate analyses of changes in community structure. Australian Journal of Ecology 1993, 18, 117-143.

86. Denger, K.; Warthmann, R.; Ludwig, W.; Schink, B., Anaerophaga thermohalophila gen. nov., sp. nov., a moderately thermohalophilic, strictly anaerobic ferentative bacterium. Int. J. Syst. Evol. Microbiol. 2002, 52.

87. Gauthier, M. J.; Lafay, B.; Christen, R.; Fernandez, L.; Acquaviva, M.; Bonin, P.; Bertrand, J.-C., Marinobacter hydrocarbonoclasticus gen. nov., sp. nov., a New, Extremely Halotolerant, Hydrocarbon-Degrading Marine Bacterium. Int. J. Syst. Bacteriol. 1992, 42, (4), 568-576.

88. Lattuati, A.; Pierre, M.; Acquaviva, M.; Bertrand, J.-C.; Largeau, C., n-Alkane degradation by Marinobacter hydrocarbonoclasticus strain SP 17: long chain -hydroxy acids as indicators of bacterial activity. Org. Geochem. 2001, 33, (1), 37-45.

89. Bruns, A.; Rohde, M.; Berthe-Corti, L., Muricuada ruestringensis gen. nov., sp. nov., facultatively anaerobic, appendaged bacterium from German North Sea intertidal sediment. Int. J. Syst. Evol. Microbiol. 2001, 51, 1997-2006. 
90. Miranda-Tello, E.; Fardeau, M.-L.; Joulian, C.; Magot, M.; Thomas, P.; Tholozan, J.-L.; Ollivier, B., Petrotoga halophila sp. nov., a thermophilic, moderately halophilic, fermentative bacterium isolated from an offshore oil well in Congo. Int J Syst Evol Microbiol. 2007, 57, (4044).

91. Wang, B.; Lai, Q.; Cui, Z.; Tan, T.; Shao, Z., A pyrene-degrading consortium from deepsea sediment of the West Pacific and its key member sp. P1. Environmental microbiology 2008, $10,(8), 1948-1963$.

92. Vila, J.; Nieto, J. M.; Mertens, J.; Springael, D.; Grifoll, M., Microbial community structure of a heavy fuel oil-degrading marine consortium: linking microbial dynamics with polycyclic aromatic hydrocarbon utilization. FEMS Microbiol. Ecol. 2010, 73, 349-362.

93. Nogi, Y.; Hosoya, S.; Kato, C.; Horikoshi, K., Colwellia piezophila sp. nov., a novel piezophilic species from deep-sea sediments of the Japan Trench. Int. J. Syst. Evol. Microbiol. 2004, 54, 1627-1631.

94. Yamada, T.; Sekiguchi, Y.; Hanada, S.; Imachi, H.; Ohashi, A.; Harada, H.; Kamagata, Y., Anaerolinea thermolimosa sp. nov., Levilinea saccharolytica gen. nov., sp. nov. and Leptolinea tardivitalis gen. nov., sp. nov., novel filamentous anaerobes, and description of the new classes Anaerolineae classis nov. and Caldilineae classis nov. in the bacterial phylum Chloroflexi. Int. J. Syst. Evol. Microbiol. 2006, 56, (1331-1340).

95. Davenport, J.; Davenport, J. L., The impact of tourism and personal leisure transport on coastal environments: A review. Estuarine, Coastal and Shelf Science 2005, 67, (1-2), 280-292.

96. Dugan, J. E.; Hubbard, D. M., Loss of Coastal Strand Habitat in Southern California: The Role of Beach Grooming. Estuaries and Coasts 2009, 33, (1), 67-77.

97. Nordstrom, K. F.; Lampe, R.; Vandemark, L. M., Restablishing Naturally Functioning Dunes on Developed Coasts Environmental Management 2000, 25, (1), 37-51.

98. Loague, K., A compartmentalized solute transport model for redox zones in contaminated aquifers: 1. Theory and development. Water Resour. Res. 2000, 36, (8), 2001-2013.

99. Turner, S.; Pryer, K. M.; Miao, V. P. W.; Palmer, J. D., Investigating deep phylogenetic relationships among cyanobacteria and plastids by small submit rRNA sequence analysis. $J$. Eukaryot. Microbiol. 1999, 46, (4), 327-338. 
100. Suzuki, M. T.; Taylor, L. T.; DeLong, E. F., Quantitative Analysis of Small-Subunit rRNA Genes in Mixed Microbial Populations via 5' - Nuclease Assays. In Appl. Environ. Microbiol., 2000; Vol. 66, pp 4605-4614. 


\section{Appendix}

Table A1. Details of sequences obtained from excising the bands from DGGE of the sand

columns.

The corresponding index numbers are highlighted in Fig. 4.5 in the text, and the depth is with respect to the position of oil deposit as in Fig. 3.3.

\begin{tabular}{|c|c|c|c|}
\hline $\begin{array}{l}\text { Column/Index } \\
\text { number/Depth }\end{array}$ & $\begin{array}{l}\text { Highest Match (GenBank } \\
\text { accession number) }\end{array}$ & $\begin{array}{l}\% \\
\text { Match }\end{array}$ & $\begin{array}{l}\text { Closest cultured relative (GenBank } \\
\text { accession number) \% Match }\end{array}$ \\
\hline Sheet $/ 1 /+2.5$ & $\begin{array}{l}\text { Uncultured bacterium clone } \\
\text { F776O8Q01AQKGB (GU764001) }\end{array}$ & 100 & $\begin{array}{l}\text { Flavobacterium sp. CKC03 } \\
\text { (JN032579) } 97\end{array}$ \\
\hline Sheet $/ 2 /+2.5$ & $\begin{array}{l}\text { Uncultured bacterium clone REP5- } \\
27 \text { (JF769674) }\end{array}$ & 98 & $\begin{array}{l}\text { Balneola sp. MOLA } 132 \\
\text { (AM990906) } 98\end{array}$ \\
\hline Sheet $/ 3 /+2.5$ & $\begin{array}{l}\text { Uncultured gamma } \\
\text { proteobacterium (AM050724) }\end{array}$ & 100 & $\begin{array}{l}\text { Pseudospirillum japonicum (NR } \\
024654) 100\end{array}$ \\
\hline Sheet/4/+2.5 & $\begin{array}{l}\text { Uncultured bacterium isolate } \\
\text { DGGE gel band } 4202 \text { (JN698231) }\end{array}$ & 100 & $\begin{array}{l}\text { Flavobacterium sp. FCS-5 } \\
\text { (JF830803) } 100\end{array}$ \\
\hline Sheet $/ 5 / 0$ & $\begin{array}{l}\text { Uncultured bacterium clone } \\
\text { PC2_P17 (HQ688408) }\end{array}$ & 97 & $\begin{array}{l}\text { Anaerophaga thermohalophila strain } \\
\text { Fru22 (NR_028963) } 97\end{array}$ \\
\hline Sheet $/ 6 / 0$ & $\begin{array}{l}\text { Uncultured bacterium clone } \\
\text { HDBW-WB34 (AB237697) }\end{array}$ & 100 & $\begin{array}{l}\text { Bacteroidales bacterium P2 } \\
\text { (HQ697914) } 97\end{array}$ \\
\hline Sheet $/ 7 / 0$ & $\begin{array}{l}\text { Uncultured Anaerophaga sp. clone } \\
\text { TCB 123x (DQ647179) }\end{array}$ & 99 & $\begin{array}{l}\text { Anaerophaga sp. HS1 (DQ517535) } \\
96\end{array}$ \\
\hline Sheet $/ 8 / 0$ & $\begin{array}{l}\text { Uncultured bacterium clone G66 } \\
\text { (DQ521123) }\end{array}$ & 93 & $\begin{array}{l}\text { Marinilabilia salmonicolor } \\
\text { (AB680721) } 89\end{array}$ \\
\hline Sheet $/ 9 / 0$ & $\begin{array}{l}\text { Uncultured bacterium clone } \\
\text { F776O8Q01AQKGB (GU764001) }\end{array}$ & 100 & $\begin{array}{l}\text { Flavobacterium columnare strain } \\
\text { RDC-1 (JN825736.1) } 99\end{array}$ \\
\hline Sheet/10/0 & $\begin{array}{l}\text { Muricauda ruestringensis DSM } \\
13258 \text { (CP002999) }\end{array}$ & 100 & $\begin{array}{l}\text { Muricauda ruestringensis DSM } \\
13258 \text { (CP002999) } 97\end{array}$ \\
\hline Sheet/11/-2.5 & $\begin{array}{l}\text { Uncultured bacterium gene } \\
\text { (AB671517) }\end{array}$ & 97 & $\begin{array}{l}\text { Psychroflexus sp. COL- } \\
60(\mathrm{HQ} 534335) 96\end{array}$ \\
\hline Sheet/12/-2.5 & $\begin{array}{l}\text { Uncultured bacterium clone } \\
\text { PC2_P17 (HQ688408) }\end{array}$ & 100 & $\begin{array}{l}\text { Anaerophaga thermohalophila strain } \\
\text { Fru22 (NR_028963) } 96\end{array}$ \\
\hline Sheet/13/-2.5 & $\begin{array}{l}\text { Uncultured bacterium clone dcpa4- } \\
72 \text { (HM050729) }\end{array}$ & 89 & $\begin{array}{l}\text { Flavobacterium filum strain EMB34 } \\
\text { (NR 043767.1) } 88\end{array}$ \\
\hline Sheet/14/-2.5 & $\begin{array}{l}\text { Uncultured bacterium clone C71 } \\
\text { (DQ521178) }\end{array}$ & 96 & Arenibacter sp. HP12 (JF751052) 95 \\
\hline Sheet/15/-2.5 & $\begin{array}{l}\text { Uncultured bacterium clone C3 } \\
\text { (DQ521168) }\end{array}$ & 99 & $\begin{array}{l}\text { Bacteroidetes sp. OL02 (JN791391) } \\
97\end{array}$ \\
\hline Sheet/16/-2.5 & $\begin{array}{l}\text { DE Marinobacter } \\
\text { hydrocarbonoclasticus } \\
\text { (FP475901) }\end{array}$ & 82 & $\begin{array}{l}\text { DE Marinobacter } \\
\text { hydrocarbonoclasticus (FP475901) } 82\end{array}$ \\
\hline Sheet/17/-5 & $\begin{array}{l}\text { Flavobacteriaceae bacterium D11- } \\
\text { 24b1(AM403225.1) }\end{array}$ & 100 & $\begin{array}{l}\text { Flavobacteriaceae bacterium D11- } \\
\text { 24b1 (AM403225) } 92\end{array}$ \\
\hline
\end{tabular}




\begin{tabular}{|c|c|c|c|}
\hline Sheet/18/-5 & $\begin{array}{l}\text { Uncultured bacterium clone G113 } \\
\text { (DQ521092.1) }\end{array}$ & 98 & $\begin{array}{l}\text { Petrotoga sp. enrichment culture } \\
\text { clone SEQ61_Clone3BP1_ANA } \\
\text { (HM059784) } 98\end{array}$ \\
\hline Sheet/19/-5 & $\begin{array}{l}\text { Uncultured bacterium clone: E140- } \\
\text { Bac-G1_27F_1_G01_003. } \\
\text { (AB671517) }\end{array}$ & 100 & $\begin{array}{l}\text { Psychroflexus sp. Antwl407 } \\
\text { (JF811035) } 100\end{array}$ \\
\hline Sheet/20/-5 & $\begin{array}{l}\text { Anaerophaga thermohalophila } \\
\text { strain Fru22 (NR 028963) }\end{array}$ & 97 & $\begin{array}{l}\text { Anaerophaga thermohalophila strain } \\
\text { Fru22 (NR 028963) } 97\end{array}$ \\
\hline Sheet/21/-5 & $\begin{array}{l}\text { Uncultured Flavobacteriaceae } \\
\text { bacterium clone BPS_L271 } \\
\text { (HQ857727) }\end{array}$ & 100 & $\begin{array}{l}\text { Salegentibacter sp. PR54-18 } \\
\text { (EU440974) } 98\end{array}$ \\
\hline Sheet/22/-5 & $\begin{array}{l}\text { Uncultured bacterium clone C3 } \\
\text { (DQ521168) }\end{array}$ & 96 & Cytophaga sp. culi-10 (JN594610) 94 \\
\hline Sheet/23/-5 & $\begin{array}{l}\text { Uncultured Nitrospirales } \\
\text { bacterium (FJ535100) }\end{array}$ & 84 & $\begin{array}{l}\text { Nitrospira moscoviensis strain NSP } \\
\text { M-1 (NR 029287) } 84\end{array}$ \\
\hline Sheet/24/-7.5 & $\begin{array}{l}\text { Uncultured bacterium clone } \\
\text { F776O8Q01AQKGB (GU764001) }\end{array}$ & 100 & $\begin{array}{l}\text { Flavobacterium sp. KJ017 } \\
\text { (JF904880) } 91\end{array}$ \\
\hline Sheet/25/-7.5 & $\begin{array}{l}\text { Uncultured soil bacterium clone } \\
\text { GO0VNXF07H3IDI (JF383890) }\end{array}$ & 96 & $\begin{array}{l}\text { Sphingomonas sp. strain } \\
\text { Pseudomonas paucimobilis Q1. } \\
\text { (X87167) } 96\end{array}$ \\
\hline Sheet/26/-7.5 & $\begin{array}{l}\text { Uncultured bacterium clone Tat- } \\
08-015 \_51 \_119 \text { (GU437616) }\end{array}$ & 97 & $\begin{array}{l}\text { Psychroflexus sp. COL-60 } \\
\text { (HQ534335) } 96\end{array}$ \\
\hline Sheet/27/-7.5 & $\begin{array}{l}\text { Uncultured bacterium clone } \\
\text { SGUS584 (FJ202346.1) }\end{array}$ & 91 & $\begin{array}{l}\text { Anaerophaga thermohalophila strain } \\
\text { Fru22 (NR_028963) } 93\end{array}$ \\
\hline Sheet/28/-7.5 & $\begin{array}{l}\text { Uncultured Verruscosispora sp. } \\
\text { clone DB5 (FJ465003) }\end{array}$ & 91 & $\begin{array}{l}\text { Verrucosispora gifhornensis strain } \\
\text { HR1-2 (NR 026445) } 87\end{array}$ \\
\hline Sheet/29/-7.5 & $\begin{array}{l}\text { Uncultured bacterium clone STU1 } \\
\text { (EU700143) }\end{array}$ & 99 & $\begin{array}{l}\text { Roseovarius sp. AMV6 (FN376425) } \\
92\end{array}$ \\
\hline Sheet/30/-7.5 & $\begin{array}{l}\text { Uncultured bacterium clone } \\
\text { GBL17O37 (HM445127) }\end{array}$ & 99 & Nitrospira sp. (AF035813) 93 \\
\hline Ball I/31/+2.5 & $\begin{array}{l}\text { Uncultured bacterium clone } \\
\text { SINH706 (HM128204) }\end{array}$ & 97 & $\begin{array}{l}\text { Psychroflexus sp. COL-60 } \\
\text { (HQ534335.1) } 91\end{array}$ \\
\hline Ball I/32/+2.5 & $\begin{array}{l}\text { Uncultured bacterium clone } \\
\text { SINH706 (HM128204) }\end{array}$ & 97 & $\begin{array}{l}\text { Psychroflexus sp. COL-60 } \\
\text { (HQ534335.1) } 93\end{array}$ \\
\hline Ball I/33/+2.5 & $\begin{array}{l}\text { Uncultured bacterium clone G66 } \\
\text { (DQ521123) }\end{array}$ & 100 & Marinilabilia sp. AK2 (FN994992) 98 \\
\hline Ball I/34/0 & $\begin{array}{l}\text { Uncultured bacterium clone } \\
\text { ABRB61 (HQ224849) }\end{array}$ & 98 & $\begin{array}{l}\text { Colwellia sp. SW2-3E (FR744837.1) } \\
98\end{array}$ \\
\hline Ball I/35/0 & $\begin{array}{l}\text { Uncultured bacterium clone } \\
\text { BXHB42 (GQ480088) }\end{array}$ & 93 & $\begin{array}{l}\text { Alpha proteobacterium SCGC } \\
\text { AAA041-L04 (HQ663353) } 92\end{array}$ \\
\hline Ball I/36/-5 & $\begin{array}{l}\text { Uncultured bacterium clone } \\
\text { F776O8Q01 AQKGB } \\
\text { (GU764001.1) }\end{array}$ & 99 & $\begin{array}{l}\text { Flavobacterium columnare strain } \\
\text { RDC-1 (JN825736) } 97\end{array}$ \\
\hline Ball I/37/-5 & $\begin{array}{l}\text { Uncultured bacterium clone G66 ( } \\
\text { DQ521123 ) }\end{array}$ & 96 & Marinilabilia sp. AK2 (FN994992) 96 \\
\hline Ball II/38/+2.5 & $\begin{array}{l}\text { Uncultured bacterium isolate PW- } \\
52(\mathrm{JN} 865727)\end{array}$ & 100 & $\begin{array}{l}\text { Marinilabilia sp. AK2 (FN994992) } \\
100\end{array}$ \\
\hline Ball II/39/0 & $\begin{array}{l}\text { Uncultured bacterium clone B3-55 } \\
(\mathrm{HQ636195})\end{array}$ & 100 & $\begin{array}{l}\text { Leptolinea sp. enrichment culture } \\
\text { clone Y223 (JF345340) } 100\end{array}$ \\
\hline
\end{tabular}




\begin{tabular}{|l|l|r|l|}
\hline $\begin{array}{l}\text { Ball II/40/- } \\
2.5 \mathrm{~cm}\end{array}$ & $\begin{array}{l}\text { Uncultured bacterium clone G66 ( } \\
\text { DQ521123 ) }\end{array}$ & 99 & Marinilabilia sp. AK2 (FN994992) 96 \\
\hline Ball II/41/-2.5 & $\begin{array}{l}\text { Uncultured bacterium clone Tat- } \\
\text { 08-015_51_119(GU437616) }\end{array}$ & 97 & $\begin{array}{l}\text { Psychroflexus } \text { sp. COL-60 } \\
\text { (HQ534335.1) 94 }\end{array}$ \\
\hline Ball II/42/-5 & $\begin{array}{l}\text { Uncultured bacterium clone } \\
\text { GDIC2IK01EQ34N (JF577442.1) }\end{array}$ & 96 & Colwellia sp. SW2-3E (FR744837) 92 \\
\hline $\begin{array}{l}\text { Ball II/43/-5, } \\
\text { Ball II/45/-7.5 }\end{array}$ & $\begin{array}{l}\text { Uncultured bacterium clone G66 ( } \\
\text { DQ521123 ) }\end{array}$ & 100 & $\begin{array}{l}\text { Marinilabilia } \text { sp. AK2 (FN994992.1) } \\
97\end{array}$ \\
\hline Ball Il/44/-7.5 & $\begin{array}{l}\text { Uncultured bacterium clone G66 } \\
\text { (DQ521123) }\end{array}$ & 94 & $\begin{array}{l}\text { Bacteroidales bacterium P2 } \\
\text { (HQ697914) 90 }\end{array}$ \\
\hline $\begin{array}{l}\text { Blank/46/+2.5, } \\
\text { Blank/47/-2.5 }\end{array}$ & $\begin{array}{l}\text { Uncultured bacterium clone C3 } \\
\text { (DQ521168) }\end{array}$ & 99 & $\begin{array}{l}\text { Bacteroidetes sp. OL02 (JN791391) } \\
\text { 97 }\end{array}$ \\
\hline Blank/48/-5 & $\begin{array}{l}\text { Uncultured bacterium clone } \\
\text { F776O8Q01 AQKGB (GU764001) }\end{array}$ & 97 & $\begin{array}{l}\text { Flavobacterium } \text { sp. CKC03 } \\
\text { (JN032579) 92 }\end{array}$ \\
\hline Blank/49/-5 & $\begin{array}{l}\text { Uncultured bacterium clone G66 } \\
\text { (DQ521123) }\end{array}$ & 94 & $\begin{array}{l}\text { Bacteroidales bacterium P2 } \\
\text { (HQ697914) 87 }\end{array}$ \\
\hline Blank/50/-7.5 & $\begin{array}{l}\text { Uncultured bacterium clone } \\
\text { GDIC2IK01EQ34N (JF577442.1) }\end{array}$ & 91 & Colwellia sp. SW2-3E (FR744837) 87 \\
\hline Blank/51/-7.5 & $\begin{array}{l}\text { Uncultured bacterium clone } \\
\text { F776O8Q01 AQKGB (GU764001) }\end{array}$ & 94 & $\begin{array}{l}\text { Flavobacterium columnare strain } \\
\text { RDC-1 (JN825736.1) 85 }\end{array}$ \\
\hline
\end{tabular}

Fig. A1. Particle size distribution of sand used in 1D sand columns.

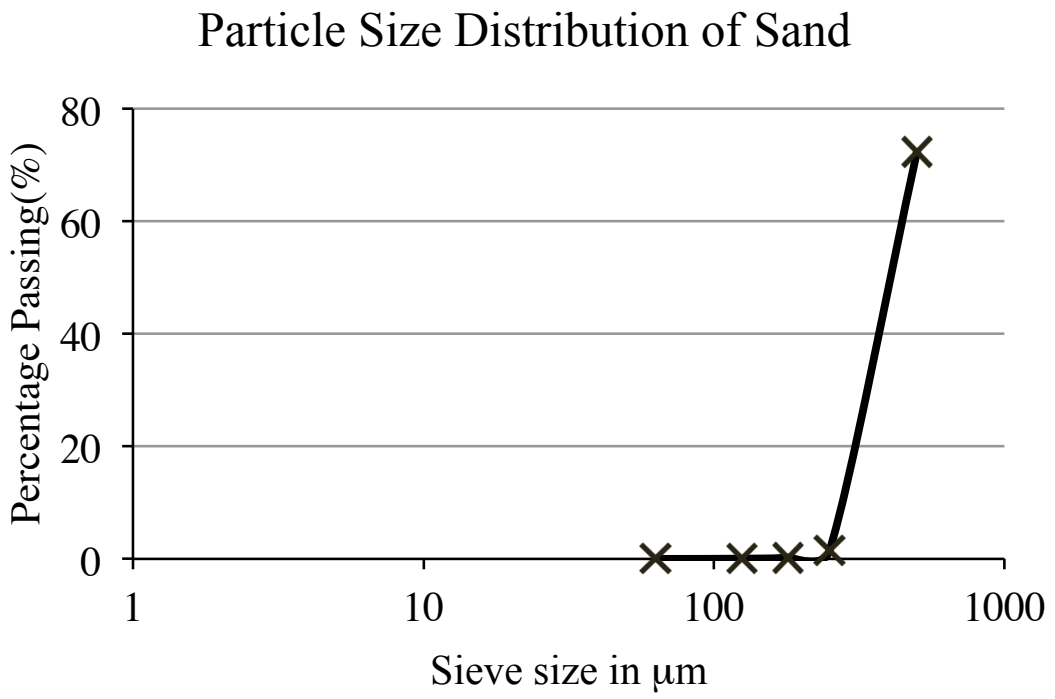


Table A2. Primer sequences and annealing temperatures employed for PCR and qPCR assays.

\begin{tabular}{|c|c|c|c|c|}
\hline Primer $^{\mathrm{a}}$ & Target gene & $\begin{array}{l}\text { Annealing } \\
\text { Temp. }\left({ }^{\circ} \mathrm{C}\right)\end{array}$ & Primer $\left(5^{\prime}-3^{\prime}\right)$ & Reference \\
\hline $8 \mathrm{~F}$ & \multirow{2}{*}{$16 \mathrm{~S} r \mathrm{rN}^{\mathrm{b}}$} & \multirow{2}{*}{50} & AGAGTTTGATCCTGGCTCAG & \multirow{2}{*}{ [99] } \\
\hline 1492R & & & \begin{tabular}{|l|} 
GGTTACCTTGTTACGACTT \\
\end{tabular} & \\
\hline I-341 F GC & \multirow[t]{2}{*}{$\begin{array}{ll}\text { V3 } & 16 \mathrm{~S} \\
\text { rRNA }\end{array}$} & \multirow[t]{2}{*}{47} & $\begin{array}{l}\text { CGCCCGCCGCGCGCGGCGGGCGG } \\
\text { GGCGGGGGCACGGGGGGCCTAC } \\
\text { GGGAGGCAGCAG }\end{array}$ & \multirow[t]{2}{*}{ [79] } \\
\hline $\mathrm{I}-533 \mathrm{R}$ & & & TIACCGIIICTICTGGCAC & \\
\hline$d s r A \_290 F$ & \multirow{2}{*}{$d s r A$} & \multirow{2}{*}{60} & $\begin{array}{l}\text { CGGCGTTGCGCATTTYCAYACVV } \\
\mathrm{T}\end{array}$ & \multirow{2}{*}{ [39] } \\
\hline$d s r A \_660 R$ & & & $\begin{array}{l}\text { GCCGGACGATGCAGHTCRTCCTG } \\
\text { RWA }\end{array}$ & \\
\hline$m c r A \_1035 F$ & \multirow{2}{*}{$m c r A$} & \multirow[t]{2}{*}{56} & $\begin{array}{l}\text { GGTGGTGTMGGATTCACACARTA } \\
\text { YGCWACAGC }\end{array}$ & \multirow{2}{*}{ [39] } \\
\hline mcrA_1530R & & & TTCATTGCRTAGTTWGGRTAGTT & \\
\hline cat23 F & \multirow{2}{*}{ cat 23} & \multirow{2}{*}{66} & CGACCTGATCTCCATGACCGA & \multirow{2}{*}[40]{} \\
\hline cat23 R & & & TCAGGTCAGCACGGTCA & \\
\hline $1369 \mathrm{~F}$ & \multirow{2}{*}{$16 \mathrm{~S} \mathrm{rRNA}^{\mathrm{b}}$} & \multirow{2}{*}{60} & CGACCTGATCTCCATGACCGA & \multirow{2}{*}[100]{} \\
\hline 1492R & & & TCAGGTCAGCACGGTCA & \\
\hline
\end{tabular}


Table A3. PCR reaction matrix ${ }^{\mathrm{a}}$

\begin{tabular}{cc}
\hline Reagent & Amount or concentration in 25 $\mu$ l master mix \\
\hline $10 \times$ PCR buffer $^{\mathrm{d}}$ & $2.5 \mu \mathrm{l}$ \\
$5 \times$ PCR buffer $^{\mathrm{d}}$ & $5 \mu \mathrm{l}$ \\
dNTPs $^{\mathrm{e}}$ & $0.2 \mathrm{mM}$ \\
Forward and reverse primer $^{\mathrm{a}}$ & $0.25 \mu \mathrm{M}$ \\
Taq DNA polymerase & $1.75 \mathrm{U}$ \\
Formamide $^{\mathrm{g}}$ & $0.25 \mu \mathrm{l}$ \\
DNA template $^{2+\mathrm{d}}$ & $1 \mu \mathrm{l}$ \\
$\mathrm{Mg}^{2+}$ & $2 \mathrm{mM}$ \\
\hline
\end{tabular}

${ }^{a}$ Integrated DNA Technologies Inc. (Coralville, IA.)

${ }^{\mathrm{d}}$ MasterTaq kit (Eppendorf, Westbury, NY) was used for PCR assays.

e (Promega Corporation, Madison, WI)

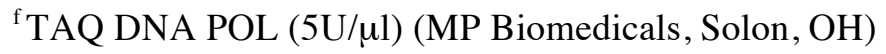

${ }^{g}$ Formamide Mol Bio Grade (Fisher Scientific Company LLC, Suwanee, GA.) 
Table A4. qPCR reaction matrix

\section{Reagent Concentration in $20 \mu \mathrm{l}$ master mix}

$\begin{array}{cc}\text { Forward and reverse primer }^{\mathrm{a}} & 0.3 \mu \mathrm{M} \\ \text { SsoFast EvaGreen Supermix } & 1 \times \\ \text { iTaq }^{\mathrm{h}} & 0.1 \mu \mathrm{l}\end{array}$

\footnotetext{
${ }^{a}$ Integrated DNA Technologies Inc. (Coralville, IA.)

h (Bio-Rad, Hercules, CA); iTaq was only used for amplifying gene specific to alpha subunit dissimilatory sulfite reductase using $d s r A \_290 \mathrm{~F}$ and $d s r A \_660 \mathrm{R}$ primer set. ${ }^{\mathrm{a}}$

All standard curves of qPCR were constructed from serial dilutions of cloned positive controls ranging from $10^{8}$ to $10^{2}$ gene copies per $\mu \mathrm{L}$. Potential effects of inhibitors were assessed by serially diluting select samples and comparing PCR efficiencies with that of standards. It was found that a dilution of 1:50 effectively minimized inhibitory effects and was applied across samples. Samples were analyzed in triplicate with a standard curve and negative control included in each run.

Cloned 16S rRNA gene inserts (Table S4) and the excised bands from DGGE gel (Table S5) were sequenced by The Virginia Bioinformatics Institute (Blacksburg, VA). Known microorganisms sharing the highest sequence similarity were determined using the BLAST alignment tool at the National Center for Biotechnology Information Web site (http://www.ncbi.nlm.nih.gov/BLAST/).
} 
Table A5. DNA sequence analysis of cloned 16S rRNA gene inserts from oiled (O) and unoiled (U) beach samples.

\begin{tabular}{|c|c|c|c|}
\hline $\begin{array}{l}\mathbf{O} / \\
\mathbf{U}\end{array}$ & $\#^{\mathrm{a}}$ & $\begin{array}{l}\text { Closest cultured relative (GenBank } \\
\text { accession number) \% Match }\end{array}$ & Taxa \\
\hline $\mathrm{O}$ & 7 & $\begin{array}{l}\text { Steroidobacter denitrificans strain FS (NR } \\
044309) 77\end{array}$ & $\begin{array}{l}\text { Bacteria; Proteobacteria; } \\
\text { Gammaproteobacteria; Xanthomonadales; } \\
\text { Sinobacteraceae; Steroidibacter. }\end{array}$ \\
\hline $\mathrm{O}$ & 1 & $\begin{array}{l}\text { Gemmatimonas aurantiaca strain T-27 } \\
\text { (NR 027529) } 95\end{array}$ & $\begin{array}{l}\text { Bacteria; } \\
\text { Gemmatimonadetes; Gemmatimonadetes; } \\
\text { Gemmatimonadales; Gemmatimonadaceae }\end{array}$ \\
\hline $\mathrm{O}$ & 2 & $\begin{array}{l}\text { Bacteroides capillosus strain ATCC } \\
29799 \text { (NR 025670) } 94\end{array}$ & $\begin{array}{l}\text { Bacteria; Firmicutes; Clostridia; } \\
\text { Clostridiales; Pseudoflavonifractor. }\end{array}$ \\
\hline $\mathrm{O}$ & 2 & $\begin{array}{l}\text { Sinobacter flavus strain CW-KD } 4 \text { 16S } \\
\text { ribosomal partial sequence (NR 044123.1) } \\
99\end{array}$ & $\begin{array}{l}\text { Bacteria; Proteobacteria; } \\
\text { Gammaproteobacteria; Xanthomonadales; } \\
\text { Sinobacteraceae; Sinobacter. }\end{array}$ \\
\hline $\mathrm{O}$ & 6 & $\begin{array}{l}\text { Holophaga foetida strain TMBS4 (NR } \\
\text { 036891.1) } 98\end{array}$ & $\begin{array}{l}\text { Bacteria; Acidobacteria; Holophageae; } \\
\text { Holophagales; Holophagaceae; Holophaga. }\end{array}$ \\
\hline $\mathrm{O}$ & 8 & $\begin{array}{l}\text { Prochlorococcus marine subsp. Pastoris } \\
\text { str. PCC } 9511 \text { (NR 028762) } 99\end{array}$ & $\begin{array}{l}\text { Bacteria; Cyanobacteria; Prochlorales; } \\
\text { Prochlorococcaceae; Prochlorococcus. }\end{array}$ \\
\hline $\mathrm{O}$ & 2 & $\begin{array}{l}\text { Nitrospira moscoviensis strain NSP M-1 } \\
\text { (NR 029287) } 97\end{array}$ & $\begin{array}{l}\text { Bacteria; Nitrospirae; Nitrospirales; } \\
\text { Nitrospira. }\end{array}$ \\
\hline $\mathrm{O}$ & 10 & $\begin{array}{l}\text { Iamia majanohamensis strain NBRC } \\
102561 \text { (NR 041634) } 94\end{array}$ & $\begin{array}{l}\text { Bacteria; Actinobacteria; Acidimicrobidae; } \\
\text { Acidimicrobiales; Acidimicrobineae; } \\
\text { Iamiaceae; Iamia. }\end{array}$ \\
\hline $\mathrm{O}$ & 4 & $\begin{array}{l}\text { Marinobacter lutaoensis strain T5054 } \\
\text { (NR 025116.1) } 96\end{array}$ & $\begin{array}{l}\text { Bacteria; Proteobacteria; } \\
\text { Gammaproteobacteria; Alteromonadales; } \\
\text { Alteromonadaceae; Marinobacter. }\end{array}$ \\
\hline $\mathrm{O}$ & 6 & $\begin{array}{l}\text { Rhodopirellula batica } \text { SH } 1 \text { strain } 1 \text { (NR } \\
\text { 043384.1) } 98\end{array}$ & $\begin{array}{l}\text { Bacteria; Planctomycetes; Planctomycetia; } \\
\text { Planctomycetales; Planctomycetaceae; } \\
\text { Rhodopirellula. }\end{array}$ \\
\hline $\mathrm{O}$ & 2 & $\begin{array}{l}\text { Singularimonas variicoloris strain MN28 } \\
\text { (NR 042175) } 98\end{array}$ & $\begin{array}{l}\text { Bacteria; Proteobacteria; } \\
\text { Gammaproteobacteria; Xanthomonadales; } \\
\text { Sinobacteraceae; Singularimonas. }\end{array}$ \\
\hline $\mathrm{O}$ & 5 & $\begin{array}{l}\text { Ectothiorhodosinua mongolicus strain M9 } \\
\text { (NR 042831) } 98\end{array}$ & $\begin{array}{l}\text { Bacteria; Proteobacteria; } \\
\text { Gammaproteobacteria; Chromatiales; } \\
\text { Ectothiorhodospiraceae; Ectothiorhodosinus. }\end{array}$ \\
\hline $\mathrm{O}$ & 1 & $\begin{array}{l}\text { Amaricoccus kaplicensis strain Ben101 } \\
\text { (NR 029201) } 98\end{array}$ & $\begin{array}{l}\text { Bacteria; Proteobacteria; } \\
\text { Alphaproteobacteria; Rhodobacterales; } \\
\text { Rhodobacteraceae; Amaricoccus. }\end{array}$ \\
\hline $\mathrm{O}$ & 4 & $\begin{array}{l}\text { Truepera radiovictrix DSM } 17093 \text { strain } \\
\text { RQ-24 (NR 043482) } 99\end{array}$ & $\begin{array}{l}\text { Bacteria; Deinococcus-Thermus; Deinococci; } \\
\text { Deinococcales; Trueperaceae; Truepera. }\end{array}$ \\
\hline $\mathrm{O}$ & 2 & $\begin{array}{l}\text { Anaerolinea thermophila strain UNI-1 } \\
\text { (NR 036818) } 90\end{array}$ & $\begin{array}{l}\text { Bacteria; Chloroflexi; Anaerolineae; } \\
\text { Anaerolineales; Anaerolineaceae; } \\
\text { Anaerolinea. }\end{array}$ \\
\hline $\mathrm{O}$ & 3 & $\begin{array}{l}\text { Burkholderia terrae strain KMY02 (NR } \\
\text { 041287) } 94\end{array}$ & $\begin{array}{l}\text { Bacteria; Proteobacteria; Betaproteobacteria; } \\
\text { Burkholderiales; Burkholderiaceae; } \\
\text { Burkholderia. }\end{array}$ \\
\hline
\end{tabular}




\begin{tabular}{|c|c|c|c|}
\hline $\mathrm{O}$ & 1 & $\begin{array}{l}\text { Denitratisoma oestradiolicum strain } \\
\text { AcBE2-1(NR 043249) } 94\end{array}$ & $\begin{array}{l}\text { Bacteria; Proteobacteria; Betaproteobacteria; } \\
\text { Rhodocyclales; Rhodocyclaceae; } \\
\text { Denitratisoma. }\end{array}$ \\
\hline $\mathrm{O}$ & 1 & $\begin{array}{l}\text { Thiobacter subterraneus strain C55 (NR } \\
\text { 024834) } 99\end{array}$ & $\begin{array}{l}\text { Bacteria; Proteobacteria; Betaproteobacteria; } \\
\text { Burkholderiales; Thiobacter. }\end{array}$ \\
\hline $\mathrm{O}$ & 8 & $\begin{array}{l}\text { Paenisporosarcina quisquiliarum strain } \\
\text { SK } 55 \text { (NR 043720) } 99\end{array}$ & $\begin{array}{l}\text { Bacteria; Firmicutes; Bacillales; } \\
\text { Planococcaceae; Paenisporosarcina. }\end{array}$ \\
\hline $\mathrm{O}$ & 3 & $\begin{array}{l}\text { Rhodospirillaceae bacterium YIM D812 } \\
\text { (NR 044596.1) } 94\end{array}$ & $\begin{array}{l}\text { Bacteria; Proteobacteria; } \\
\text { Alphaproteobacteria; Rhodospirillales; } \\
\text { Rhodospirillaceae; Fodinicurvata. }\end{array}$ \\
\hline $\mathrm{O}$ & 2 & $\begin{array}{l}\text { Brevundimonas terrae strain KSL-145 } \\
\text { (NR 043726) } 97\end{array}$ & $\begin{array}{l}\text { Bacteria; Proteobacteria; } \\
\text { Alphaproteobacteria; Caulobacterales; } \\
\text { Caulobacteraceae; Bervundimonas. }\end{array}$ \\
\hline $\mathrm{O}$ & 1 & $\begin{array}{l}\text { Thiobacter subterraneus strain C55 (NR } \\
\text { 024834.1) } 97\end{array}$ & $\begin{array}{l}\text { Bacteria; Proteobacteria; Betaproteobacteria; } \\
\text { Burkholderiales; Thiobacter. }\end{array}$ \\
\hline $\mathrm{O}$ & 2 & $\begin{array}{l}\text { Desulfomonile limimaris strain DCB-M } \\
\text { (NR 025079) } 94\end{array}$ & $\begin{array}{l}\text { Bacteria; Proteobacteria; Deltaproteobacteria; } \\
\text { Syntrophobacterales; Syntrophaceae; } \\
\text { Desulfomonile. }\end{array}$ \\
\hline $\mathrm{O}$ & 1 & $\begin{array}{l}\text { Salegentibacter sp. PR54-18 (EU440974) } \\
99\end{array}$ & Bacteria; Bacteroidetes; Flavobacteriia. \\
\hline $\mathrm{O}$ & 5 & Flavobacterium sp. KJ017 (JF904880) 98 & $\begin{array}{l}\text { Bacteria; Bacteroidetes; Flavobacteriia; } \\
\text { Flavobacteriales; } \\
\text { Flavobacteriaceae; Flavobacterium. }\end{array}$ \\
\hline $\mathrm{O}$ & 2 & $\begin{array}{l}\text { Psychroflexus sp. COL-60 (HQ534335) } \\
94\end{array}$ & Bacteria; Bacteroidetes; Flavobacteriia. \\
\hline $\mathrm{O}$ & 6 & $\begin{array}{l}\text { Flavobacterium columnare strain RDC-1 } \\
\text { (JN825736) } 99\end{array}$ & $\begin{array}{l}\text { Bacteria; Bacteroidetes; Flavobacteriia; } \\
\text { Flavobacteriales; } \\
\text { Flavobacteriaceae; Flavobacterium. }\end{array}$ \\
\hline $\mathrm{O}$ & 4 & $\begin{array}{l}\text { Flavobacterium sp. CKC03 (JN032579) } \\
98\end{array}$ & $\begin{array}{l}\text { Bacteria; Bacteroidetes; Flavobacteriia; } \\
\text { Flavobacteriales; } \\
\text { Flavobacteriaceae; Flavobacterium. }\end{array}$ \\
\hline $\mathrm{O}$ & 6 & $\begin{array}{l}\text { Verrucosispora sp. enrichment culture } \\
\text { clone SEQ24_3AClone_AER } \\
\text { (HM059747) } 98\end{array}$ & $\begin{array}{l}\text { Bacteria; Actinobacteria; Actinobacteridae; } \\
\text { Actinomycetales;Micromonosporineae; } \\
\text { Micromonosporaceae; environmental } \\
\text { samples. }\end{array}$ \\
\hline $\mathrm{U}$ & 8 & $\begin{array}{l}\text { Denitratisoma oestradiolicum strain } \\
\text { AcBE2-1(NR 043249) } 94\end{array}$ & $\begin{array}{l}\text { Bacteria; Proteobacteria; Betaproteobacteria; } \\
\text { Rhodocyclales; Rhodocyclaceae; } \\
\text { Denitratisoma. }\end{array}$ \\
\hline $\mathrm{U}$ & 6 & $\begin{array}{l}\text { Luteolibacter pohnpeiensis strain A4T-83 } \\
\text { (NR 041625) } 93\end{array}$ & $\begin{array}{l}\text { Bacteria; Verrucomicrobia; } \\
\text { Verrucomicrobiae; Verrucomicrobiales; } \\
\text { Verrucomicrobiaceae; Luteolibacter. }\end{array}$ \\
\hline $\mathrm{U}$ & 4 & $\begin{array}{l}\text { Marinobacter lutaoensis strain T5054 } \\
\text { (NR 025116.1) } 89\end{array}$ & $\begin{array}{l}\text { Bacteria; Proteobacteria; } \\
\text { Gammaproteobacteria; Alteromonadales; } \\
\text { Alteromonadaceae; Marinobacter. }\end{array}$ \\
\hline $\mathrm{U}$ & 8 & $\begin{array}{l}\text { Desulfomonile limimaris strain DCB-M } \\
\text { (NR 025079) } 94\end{array}$ & $\begin{array}{l}\text { Bacteria; Proteobacteria; Deltaproteobacteria; } \\
\text { Syntrophobacterales; Syntrophaceae; } \\
\text { Desulfomonile. }\end{array}$ \\
\hline $\mathrm{U}$ & 9 & $\begin{array}{l}\text { Heliorestis baculata strain OS H1(NR } \\
028782.1) 94\end{array}$ & $\begin{array}{l}\text { Bacteria; Firmicutes; Clostridia; } \\
\text { Clostridiales; Heliobacteriaceae; Heliorestis. }\end{array}$ \\
\hline $\mathrm{U}$ & 5 & Psychroflexus sp. COL-60(HQ534335) 89 & Bacteria; Bacteroidetes; Flavobacteriia; \\
\hline
\end{tabular}




\begin{tabular}{|c|c|c|c|}
\hline & & & $\begin{array}{l}\text { Flavobacteriales; Flavobacteriaceae; } \\
\text { Flavobacterium. }\end{array}$ \\
\hline $\mathrm{U}$ & 6 & $\begin{array}{l}\text { Flavobacterium columnare strain RDC-1 } \\
\text { (JN825736) } 95\end{array}$ & Bacteria; Bacteroidetes; Flavobacteria. \\
\hline $\mathrm{U}$ & 1 & $\begin{array}{l}\text { Flavobacterium sp. CKC03 (JN032579) } \\
98\end{array}$ & $\begin{array}{l}\text { Bacteria; Bacteroidetes; Flavobacteriia; } \\
\text { Flavobacteriales; Flavobacteriaceae; } \\
\text { Flavobacterium. }\end{array}$ \\
\hline $\mathrm{U}$ & 9 & Flavobacterium sp. FCS-5 (JF830803) 92 & $\begin{array}{l}\text { Bacteria; Bacteroidetes; Flavobacteriia; } \\
\text { Flavobacteriales; Flavobacteriaceae; } \\
\text { Flavobacterium. }\end{array}$ \\
\hline $\mathrm{U}$ & 3 & $\begin{array}{l}\text { Flavobacteriaceae bacterium D11-24b1 } \\
\text { (AM403225) } 95\end{array}$ & $\begin{array}{l}\text { Bacteria; Bacteroidetes; Flavobacteriia; } \\
\text { Flavobacteriales; Flavobacteriaceae. }\end{array}$ \\
\hline $\mathrm{U}$ & 5 & $\begin{array}{l}\text { Flavobacterium filum strain EMB34 (NR } \\
\text { 043767.1) } 98\end{array}$ & $\begin{array}{l}\text { Bacteria; Bacteroidetes; Flavobacteriia; } \\
\text { Flavobacteriales; Flavobacteriaceae; } \\
\text { Flavobacterium. }\end{array}$ \\
\hline $\mathrm{U}$ & 7 & $\begin{array}{l}\text { Leptolinea sp. enrichment culture clone } \\
\text { Y223 (JF345340) } 87\end{array}$ & $\begin{array}{l}\text { Bacteria; Chloroflexi; Anaerolineae; } \\
\text { Anaerolineales; Anaerolineaceae; Leptolinea; } \\
\text { environmental samples. }\end{array}$ \\
\hline $\mathrm{U}$ & 11 & $\begin{array}{l}\text { Prochlorococcus marine subsp. Pastoris } \\
\text { str. PCC } 9511 \text { (NR 028762) }\end{array}$ & $\begin{array}{l}\text { Bacteria; Cyanobacteria; Prochlorales; } \\
\text { Prochlorococcaceae; Prochlorococcus. }\end{array}$ \\
\hline $\mathrm{U}$ & 4 & $\begin{array}{l}\text { Iamia majanohamensis strain NBRC } \\
102561 \text { (NR 041634) } 94\end{array}$ & $\begin{array}{l}\text { Bacteria; Actinobacteria; Acidimicrobidae; } \\
\text { Acidimicrobiales; Acidimicrobineae; } \\
\text { Iamiaceae; Iamia. }\end{array}$ \\
\hline $\mathrm{U}$ & 2 & $\begin{array}{l}\text { Sphingomonas sp. strain Pseudomonas } \\
\text { paucimobilis Q1. (X87167) } 96\end{array}$ & $\begin{array}{l}\text { Bacteria; Proteobacteria; } \\
\text { Alphaproteobacteria; } \\
\text { Sphingomonadales;Sphingomonadaceae; } \\
\text { Sphingomonas. }\end{array}$ \\
\hline $\mathrm{U}$ & 6 & Cytophaga sp. N05VI (AJ786088) 97 & $\begin{array}{l}\text { Bacteria; Bacteroidetes; Cytophagia; } \\
\text { Cytophagales; Cytophagaceae;Cytophaga. }\end{array}$ \\
\hline $\mathrm{U}$ & 4 & Marinilabilia sp. AK2 (FN994992) & $\begin{array}{l}\text { Bacteria; Bacteroidetes; Bacteroidia; } \\
\text { Bacteroidales; Marinilabiaceae; } \\
\text { Marinilabilia. }\end{array}$ \\
\hline $\mathrm{U}$ & 2 & $\begin{array}{l}\text { Rhodospirillaceae bacterium YIM D812 } \\
\text { (NR 044596.1) }\end{array}$ & $\begin{array}{l}\text { Bacteria; Planctomycetes; Planctomycetia; } \\
\text { Planctomycetales; Planctomycetaceae; } \\
\text { Rhodopirellula. }\end{array}$ \\
\hline
\end{tabular}

$\#^{\mathrm{a}}$ : Number of similar clones in the restriction digest image of 100 clones of $\mathrm{U}$ and $\mathrm{O}$ samples each. 


\section{A6. Hotelling's t-square to compare GC MS analysis of the tar balls and sheet oil deposit}

Hotelling's t-square test was done to compare the chemical composition of tar balls and sheet samples collected from the beach during the field survey. The test was done using the package ISCNP [83].

\section{R Code:}

\#Data was bound in a data.frame before running this test

\#C\#, where \#ranges from 11 to 25 are representatives of n-alkanes with \# C atoms.

library(ICSNP)

(m1 <- with(oil, HotellingsT2( cbind(C11, C12, C13, C14, C15, C16, C17, C18, C19, C20, C21, C22, C23, C24, C25) geom))

\section{A7. Linear mixed-effect modeling of $\mathrm{DO}$ and $\mathrm{SO}_{4}$}

A linear mixed-effect model was fit to dissolved oxygen and sulfate of sand column effluents [84] using corAR1 as a correlation structure. corAR1 was selected as correlation structure after fitting an autoregressive time series model to the data by default selecting the complexity by Akaike information criterion (AIC).

\begin{tabular}{|l|l|l|}
\hline Column & Intercept & Slope \\
\hline Sheet & 4.354 & -0.0637 \\
\hline Ball & 5.217 & -0.0677 \\
\hline Blank & 5.7366 & -0.0449 \\
\hline
\end{tabular}

R Code:

Do.lme.6<-lme(DO Day*Ones, correlation=corAR1 (form $=\sim 1 \mid$ Label $)$, data=x $)$

A similar code was used for analysis of $\mathrm{SO}_{4}$ data.

\section{A8. Analysis for significance of $\mathrm{qPCR}$ results for $\operatorname{mcrA}, \operatorname{dsr} \mathrm{A}$, and $\operatorname{cat} 23$ as determined by}

\section{Friedman rank sum test.}

Friedman rank sum test, which is a non-parametric alternative for two-factor Anova, is reported in this study because of only single sampling point per depth in sheet and blank columns. Also, Anova requires normality of data as a pre-requisite and a normality test 'Shapiro-Wilk test' 
failed to prove normality in data $\left(\mathrm{p}<10^{-5}, \mathrm{~W}=0.7588\right)$.

However, there exist an issue with using Friedman rank sum test that it stands good for only single data points, whereas the duplicate ball columns together supplied two data points per depth. A two-factor test was chosen over single-factor test because graphs (Fig. 4.9) show that there is effect of both depth and column type on gene copy numbers, and the interaction plots show that there are interaction effects too.

Autocorrelation between samples from the same column was also tested and verified not significant for each column type as shown in Fig. A8.1- A8.3.
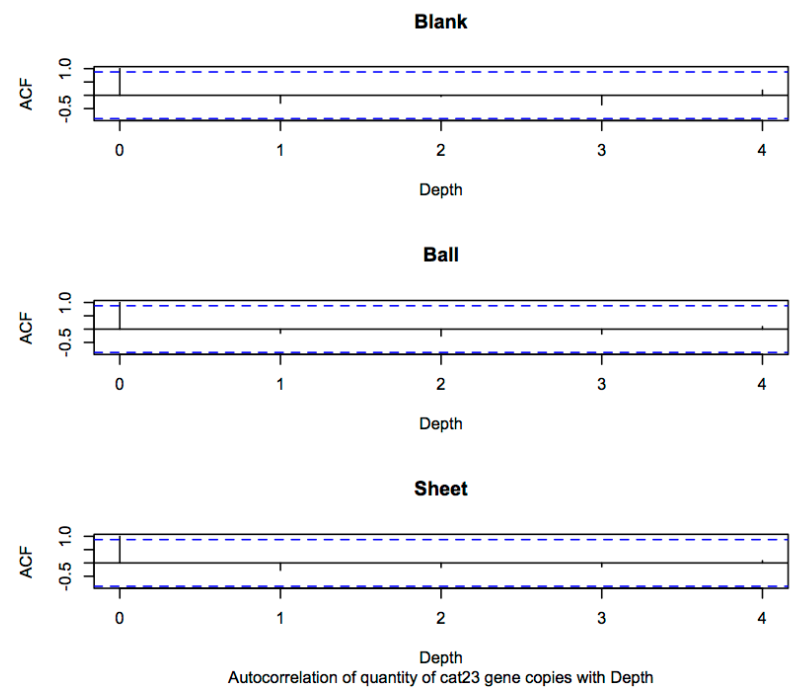

Fig. A8.1. Autocorrelation plot for cat23 gene copies. 


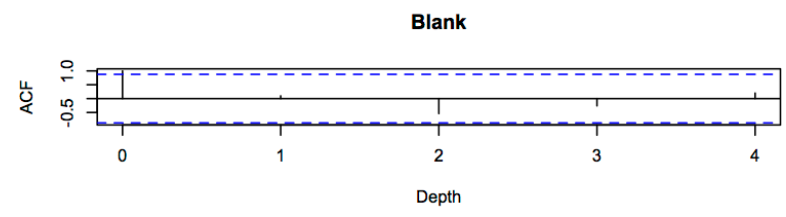

Ball
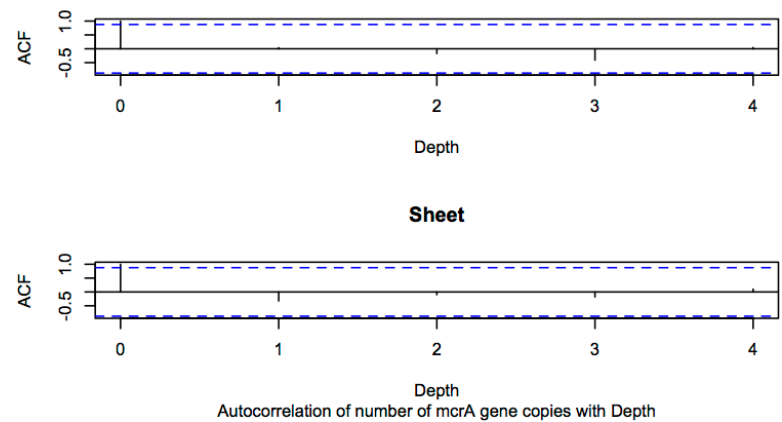

Fig. A8.2. Autocorrelation plot for $m c r A$ gene copies.
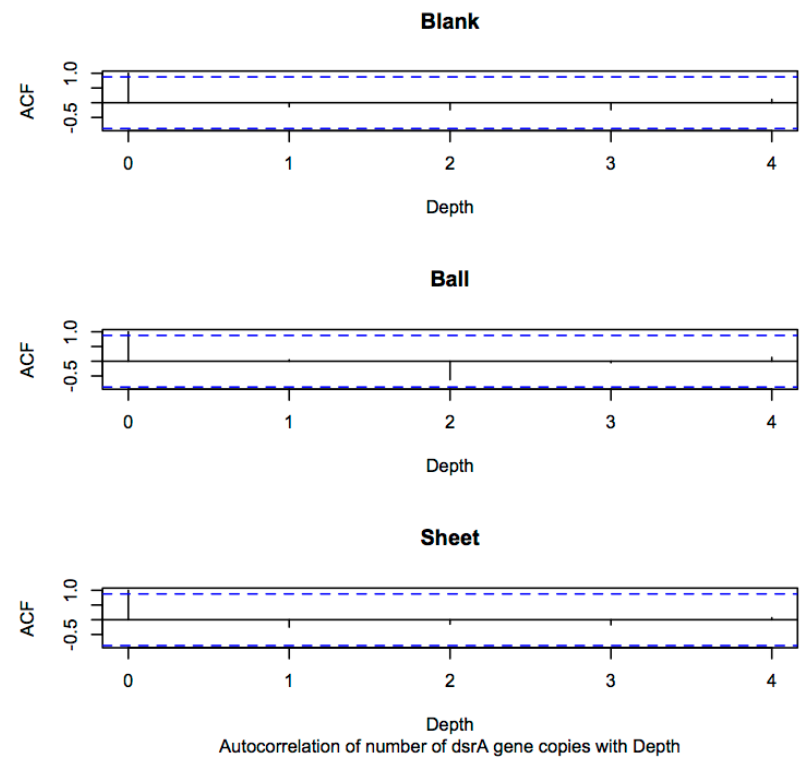

Fig. A8.3 Autocorrelation plot for $d s r A$ gene copies.

R Code for autocorrelation with depth:

\#cat23

cblank<-c(0.375,1.103,0.676,0.65,0.37)

cab<-acf(cblank)

$\operatorname{par}(\operatorname{mfrow}=\mathrm{c}(3,1))$ 


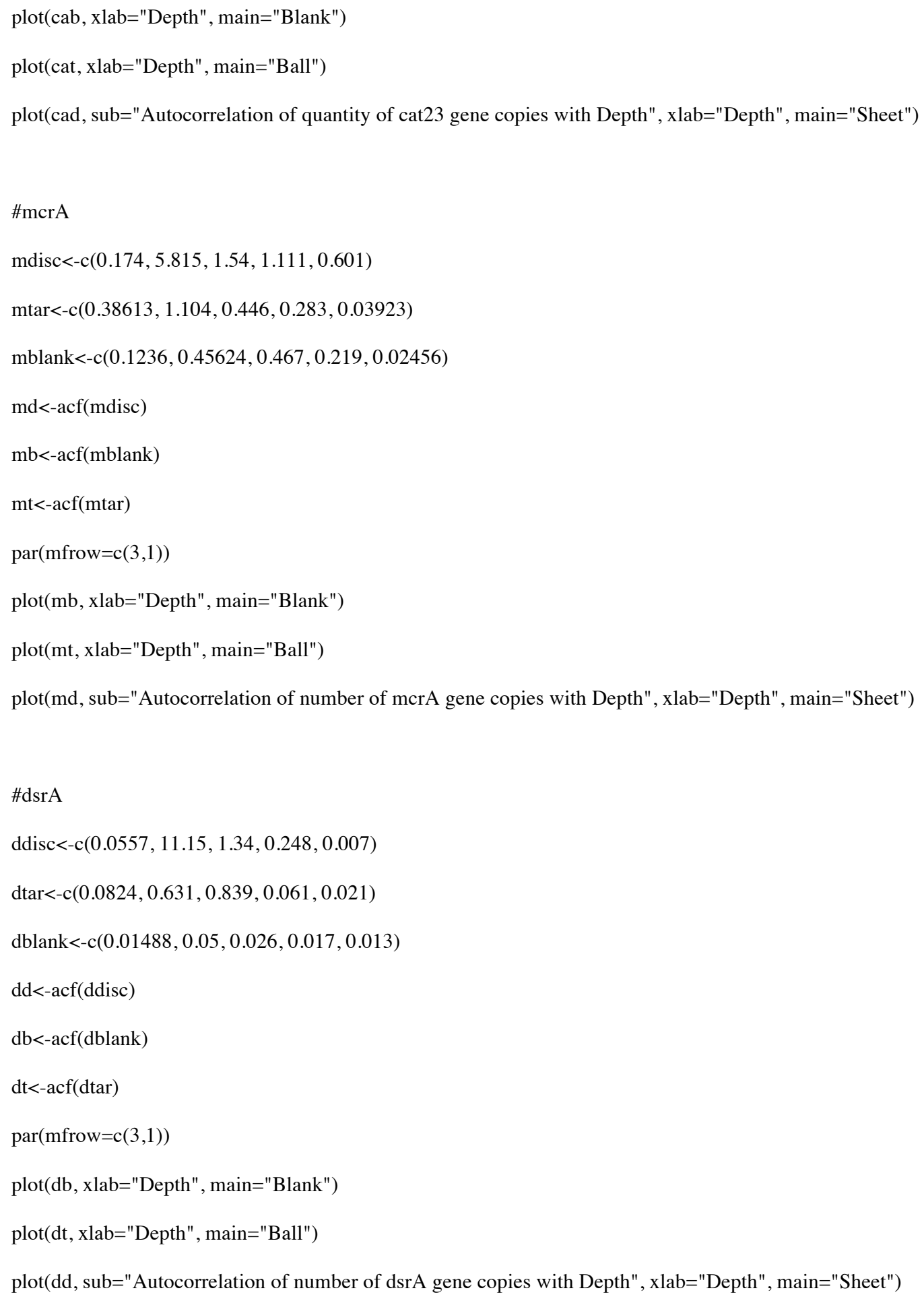

\section{Friedman rank sum test $\mathrm{R}$ code:}

\#In the .csv file "qpcr", columns have been named in this format: geneColumn, where gene is either dsra, cat, mcra, or \#S for dsrA, cat23, mcrA, 16S rRNA respectively; and Column is either S, B, or Bl for Sheet, Balls, and Blank \#respectively. 
q<-read.csv("qpcr.csv")

d<-(matrix (c(q\$dsraS, q\$dsraB, q\$dsraBl), nrow=5, dimnames = list(1:5, c("Sheet", "Ball", "Blank"))))

\#friedman.test

\#The null hypothesis is that apart from an effect of blocks,

\#the location parameter of $y$ is the same in each of the groups.

\#If y is a matrix, groups and blocks are obtained from the column and row indices, respectively.

\#NA's are not allowed in groups or blocks; if y contains NA's, corresponding blocks are removed.

friedman.test(d) \# apart from the effect of depth, column type has some imp too

friedman.test $(\mathrm{t}(\mathrm{d}))$ \# apart from the effect of column type, depth has some imp too

$>$ friedman.test(d) \# apart from the effect of depth, column type has some imp too

Friedman rank sum test

data: d

Friedman chi-squared $=8.4, \mathrm{df}=2, \mathrm{p}$-value $=0.015$

$>$ friedman.test(t(d)) \# apart from the effect of column type, depth has some imp too

Friedman rank sum test

data: $\mathrm{t}(\mathrm{d})$

Friedman chi-squared $=11.4667, \mathrm{df}=4, \mathrm{p}$-value $=0.02179$

c<-(matrix (c(q\$catS, q\$catB, q\$catB1), nrow=5, dimnames = list(1:5, c("Sheet", "Ball", "Blank"))))

friedman.test(c) \# apart from the effect of depth, column type has some imp too

friedman.test $(\mathrm{t}(\mathrm{c}))$ \# apart from the effect of column type, depth has some imp too

$>$ friedman.test(c) \# apart from the effect of depth, column type has some imp too 
Friedman rank sum test

data: c

Friedman chi-squared $=10, \mathrm{df}=2, \mathrm{p}$-value $=0.006738$

$>$ friedman.test $(\mathrm{t}(\mathrm{c}))$ \# apart from the effect of column type, depth has some imp too

Friedman rank sum test

data: $\mathrm{t}(\mathrm{c})$

Friedman chi-squared $=9.8667, \mathrm{df}=4, \mathrm{p}$-value $=0.04273$

m<-(matrix (c $(q \$ m c r a S, q \$ m c r a B, q \$ m c r a B 1)$, nrow=5, dimnames = list(1:5, c("Sheet", "Ball", "Blank")))

friedman.test(m) \# apart from the effect of depth, column type has some imp too

friedman.test $(\mathrm{t}(\mathrm{m}))$ \# apart from the effect of column type, depth has some imp too

$>$ friedman.test(m) \# apart from the effect of depth, column type has some imp too

Friedman rank sum test

data: $m$

Friedman chi-squared $=8.4, \mathrm{df}=2, \mathrm{p}$-value $=0.015$

$>$ friedman.test $(\mathrm{t}(\mathrm{m}))$ \# apart from the effect of column type, depth has some imp too

Friedman rank sum test

data: $\mathrm{t}(\mathrm{m})$

Friedman chi-squared $=10.9333, \mathrm{df}=4, \mathrm{p}$-value $=0.02732$ 